2. To: (Receiving Organization)
Distribution

8. Originator Remarks:

This document is being released into the supporting document system for retrievability purposes.

11. Receiver Remarks: ' 11A. Design Baseline Document? [] Yes [X] No For release.

3. From: (Originating organization)
Technical Basis and Planning

6. Design Authority/ Design Agent/Cog. Engr.:

D. L. Banning
4. Related EDT No.:

$\mathrm{N} / \mathrm{A}$

7. Purchase Order No, :

N/A

9. Equip./Component No.:

$\mathrm{N} / \mathrm{A}$

10. Systen/Bldg./Facility: $241-Z-361$

12. Major Assm. Dwg. No.: N/A

13. Permit/Permit Application No.: $\mathrm{N} / \mathrm{A}$

14. Required Response Date: 09/02/98

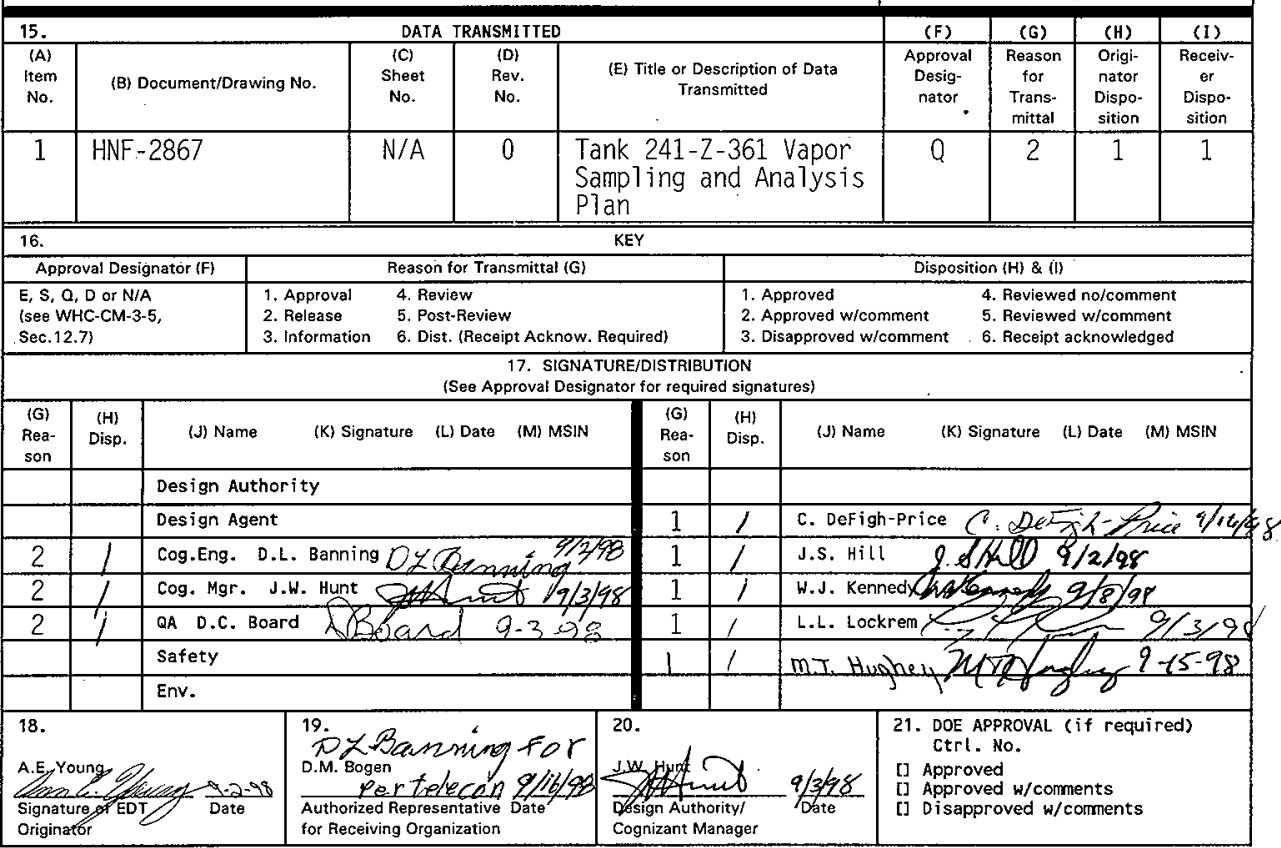

BD-7400-172-2 (05/96) GEFO97 


\title{
Tank 241-Z-361 Vapor Sampling and Analysis Plan
}

\author{
D. L. Banning
}

Lockheed Martin Hanford, Corp., Richland, WA 99352

U.S. Department of Energy Contract DE-AC06-96RL13200

$\begin{array}{lll}\text { EDT/ECN: } & \text { EDT }-622470 & \text { UC: } 2070 \\ \text { Org Code: } & 7 A 110 & \text { Charge Code: } \\ \text { B\&R Code: } & \text { EW } 3120074 & \text { Tota] Pages: } 175\end{array}$

Key Words: Tank 241-Z-361, 241-Z-361, Z-361, Vapor, Sampling, Ana 1ysis, Plan, Tank Structure

Abstract: N/A

Teflon is a registered trademark of E. I. DuPont DeNemours and Co.

Draeger-Tube is a registered trademark of Draeger Werk Ag.

TRADEMARK DISCLAIMER. Reference herein to any specific comercial product, process, or service by trade name, trademark, manufacturer, or otherwise, does not necessarily constitute or imply its endorsement, recommendation, or favoring by the United States Government or any agency thereof or its contractors or subcontractors.

Printed in the United States of America. To obtain copies of this document, contact: Document Control Services, P.0. Box 950, Mailstop H6-08, Richland WA 99352, Phone (509) 372-2420; Fax (509) 376-4989.
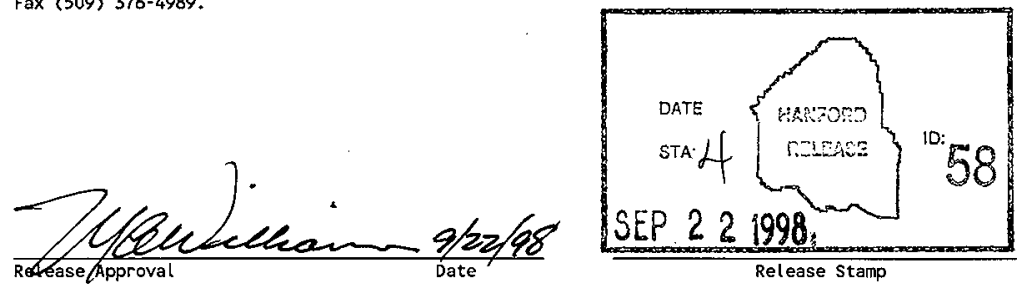

\section{Approved for Public Release}




\section{Tank 241-Z-361 Vapor Sampling Analysis Plan}

\section{S. Hill}

Waste Management Hanford Corporation

M. Hughey

Lockheed Martin Hanford Corporation

C. Miller

Northwest Instrument Systems Inc.

M. Miller

Environmental Quality Management

C. Narquis

Environmental Quality Management

September 1, 1998 
HNF-2867, Rev. 0

\section{ACKNOWLEDGMENTS}

\section{Technical Contributors:}

Dave Banning

John Bates

Don Board

Duane Bogen

Cherri DeFigh-Price

Keith Gray

David Haring

Andrea Hopkins

Wally Kennedy

Allen Lilley

Matt Nolan

Rampur Viswanath

U.S. Department of Energy, Richland Operations Office:

Suzanne Clarke

U.S. Environmental Protection Agency:

Dennis Faulk

Washington State Department of Ecology:

Gail Laws

Administrative Support:

D Baxter, EQM

R Browne, EQM 


\section{EXECUTIVE SUMMARY}

Tank 241-Z-361 is identified in the Hanford Federal Facility Agreement and Consent Order (commonly referred to as the Tri-Party Agreement), Appendix C, (Ecology et al. 1994) as a unit to be remediated under the authority of the Comprehensive Environmental Response,

Compensation, and Liability Act of 1980 (CERCLA). As such, the U.S. Environmental Protection Agency will serve as the lead regulatory agency for remediation of this tank under the CERCLA process. At the time this unit was identified as a CERCLA site under the Tri-Party Agreement, it was placed within the 200-ZP-2 Operable Unit. In 1997, The Tri-parties redefined 200 Area Operable Units into waste groupings (Waste Site Grouping for 200 Areas Soils Investigations [DOE-RL 1992 and 1997]). A waste group contains waste sites that share similarities in geological conditions, function, and types of waste received. Tank 241-Z-361 is identified within the CERCLA Plutonium/Organic-rich Process Condensate/Process Waste Group (DOE-RL 1992).

The Plutonium/Organic-rich Process Condensate/Process Waste Group has been prioritized for remediation beginning in the year 2004. Results of Tank 216-Z-361 sampling and analysis described in this Sampling and Analysis Plan (SAP) and in the SAP for sludge sampling (to be developed) will determine whether expedited response actions are required before 2004 because of the hazards associated with tank contents. Should data conclude that remediation of this tank should occur earlier than is planned for the other sites in the waste group, it is likely that removal alternatives will be analyzed in a separate Engineering Evaluation/Cost Analysis (EE/CA). Removal actions would proceed after the U.S. Environmental Protection Agency (EPA) signs an Action Memorandum describing the selected removal alternative for Tank 216-Z-361. If the data conclude that there is no immediate threat to human health and the environment from this tank, remedial actions for the tank will be defined in a feasibility study for the entire waste group.

Tank 241-Z-361 is an inactive underground tank within the fenced area of the Plutonium Finishing Plant (PFP) at the Hanford Nuclear Reservation near Richland, Washington (DOE-RL 1992). Tank $241-Z-361$ is located approximately $73.15 \mathrm{~m}$ (240 ft) south of Building $236-Z$. This tank received all low-salt, liquid effluents discharged from PFP processes from 1949 through 1973. The tank's purpose was to allow solids to settle out of the liquid waste before it was disposed of to ground via the PFP cribs. The tank was taken out of service in 1973 and sealed in 1985.

The 1997 PFP chemical hazard assessment identified potential hazards associated with the tank which were not completely evaluated and controlled within the current PFP authorization basis. These included potential flammable gas accumulation within the tank since it was sealed in 1985 , potential for inadvertent criticality, and potential structural integrity degradation due to degradation of the concrete and corrosion of reinforcing bars. An Unreviewed Safety Question (USQ) was declared in late 1997 and interim safety controls were imposed which restrict sparkand flame-producing activities in the vicinity of the tank and which prevent traffic over the tank. 
The 241-Z-361 Tank Justification for Continued Operations (JCO) provides the safety assessment of potential hazards and accident scenarios. It also authorizes a series of activities to define the actual hazards associated with the tank. Phase I of the JCO provides a safety basis for and describes the operations and controls for opening the tank safely, resolving structural integrity and flammable gas issues, and generally assessing the condition of the tank contents. Phase II will consist of actual sludge sampling and characterization. Together, Phase I and Phase II JCO authorize activities that will generate data and observations necessary to perform feasibility studies for an ultimate remediation approach.

This SAP describes a subset of Phase I JCO activities: initial opening of the first sealed riser, venting excess pressure (if any), installation of a breather filter on the riser, sampling the interior tank vapor, chemical analysis of the collected vapor samples, and videography of the interior of the tank. This SAP does not describe soil or waste sampling. Phase II activities (waste sampling and analysis) will be covered under a separate SAP.

Some incidental soil movement $<1 \mathrm{yd}^{3}\left(0.914 \mathrm{~m}^{3}\right)$ and removal may occur in order to level equipment and place safety and radiation-control signs.

Pre-sampling activities include riser and work-area preparation, replacement of the riser bolts with non-sparking bolts, and installation of a glovebag containment around the riser. Provision for weather protection may also be constructed around the worksite.

Sampling activities start by carefully removing the riser flange in a way which allows controlled venting of any pressure while maintaining a non-flammable atmosphere within the glovebag. The glovebag design provides for active purging using an inert gas if necessary to maintain nonflammability within the glovebag. When the riser has been opened, a breather filter will be installed. The breather filter assembly contains an integral vapor sampling port which will enable the collection of tank dome-space vapor samples without the need for additional containment. Tank vapor samples will be collected as whole-air samples in SUMMA ${ }^{\circledR}$ canisters and captured within sorbent trains. The samples will be analyzed for a series of chemical and radiological parameters including potential toxic air pollutants (TAP) and flammable gas constituents.

After the breather filter is in-place, the tank will be allowed to vent passively through the breather filter. A second riser will be opened and a video camera will be lowered into the tank dome space. The video camera will be used to document the condition of the interior of the tank and the waste surface.

Post-sampling activities include restoration of the tank area to original conditions. The breather filter assembly will remain to provide passive venting for the tank.

Successful completion of the activities described in this SAP will prepare the tank for, and gather information to support, future waste sampling and tank closure activities. Specifically:

- provide data to ensure environmental air emission regulatory requirements are met;

- provide data relative to air emission, flammable gas and toxicity safety conditions; and, 
- provide video which will assist in confirming that the tank structural integrity is sufficient to safely support human and vehicle traffic loads applied during future activities.

Section 1.0 of this SAP includes background history of the tank and its contents. In addition, a summary of the Tank $241-Z-361$ data quality objectives are also presented.

Section 2.0 describes the tasks, procedures, and specifications of the field activities to be accomplished as part of the scope of the JCO, and specifically those tasks which are directly authorized by this SAP.

Section 3.0 describes the quality assurance and quality control elements required for the activities, as well as their definition and specifications.

Appendices A and B describe the radiological and non-radiological air emissions estimates and resulting emission controls. This is provided in accordance with CERCLA requirements as an applicable or relevant and appropriate requirement. To determine the best available control technologies, assure compliance with applicable Federal and State substantive emissions and design standards, and establish the appropriate monitoring and notification requirement (i.e., appropriate documentation to demonstrate compliance) for radioactive and non-radioactive air emissions, Appendices A and B are in the format of a Clean Air Act notice of construction application. Appendix $\mathrm{C}$ is the Project Health and Safety Plan. 


\section{TABLE OF CONTENTS}

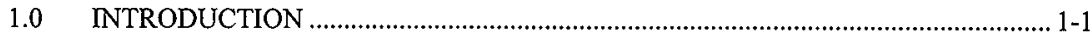

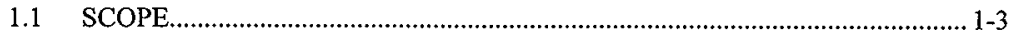

1.2 TANK 241-Z-361 DESCRIPTION ……........................................................ 1-3

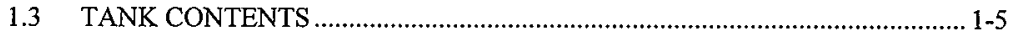

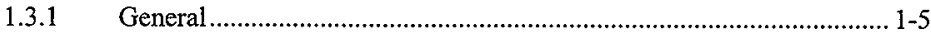

1.3.2 Historical Process Records ................................................................. 1-5

1.3.3 Historical Characterization Data........................................................ 1-6

1.4 STATEMENT OF THE PROBLEM ......................................................... 1-9

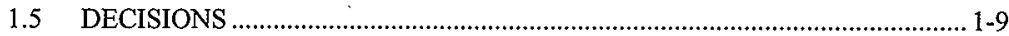

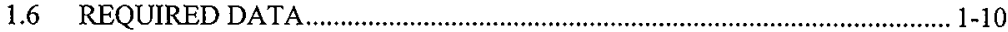

1.7 DATA UNCERTAINTY REQUIREMENTS …........................................ 1-11

1.8 VAPOR SAMPLING AND VIDEOGRAPHY PROJECT DESIGN .................. 1-11

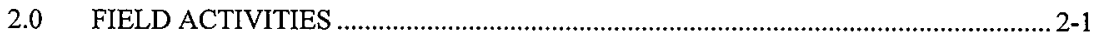

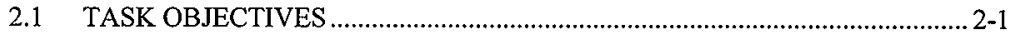

2.2 WORK AREA AND RISER PREPARATION ……............................................ 2-2

2.3 RELIEF OF INITIAL TANK PRESSURE................................................. 2-2

2.4 INSTALLATION OF BREATHER FILTER ……....................................... 2-3

2.5 TANK VAPOR SAMPLING ....................................................................... 2-3

2.5.1 Preparation of Sampling Containers ................................................... 2-3

2.5.2 Vapor Sampling Activities............................................................. 2-3

2.5.3 Field Monitoring ................................................................................ 2-5

2.5.4 Radiation Release and Screening....................................................... 2-5

2.5.5 Vapor Sampling Quality Control ....................................................... 2-6

2.5.6 Documentation.............................................................................. 2-6

2.5.7 Modifications, Deviations, Changes, and Observations ....................... 2-6

2.6 LABORATORY ANALYSIS OF TANK VAPOR SAMPLES ……................. 2-7

2.6.1 Sample Management..................................................................... 2-7

2.6.2 Chemical and Radiological Analysis .............................................2-7

2.6.3 Laboratory Analytical Quality Control ................................................2-7

2.6.4 Data Reporting ..............................................................................2-8

2.7 TANK INTERIOR VIDEOGRAPHY ....................................................... 2-10

2.8 WORK AREA CLEANUP …….............................................................. 2-11

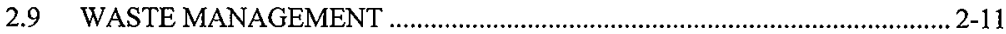

2.9.1 Field-generated Waste ............................................................... 2-12

2.9.2 Samples And Associated Waste.......................................................... 2-12

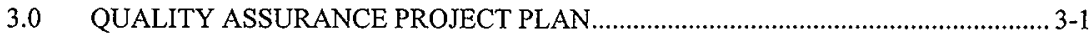

$3.1 \quad$ PROJECT MANAGEMENT ……….............................................................. 3-1

3.1.1 Project and Task Organization................................................................. 3-1

3.1.2 Roles and Responsibilities................................................................. 3-1

3.1.3 Data Users ....................................................................................... 3-4 
3.2 QUALITY OBJECTIVES AND CRITERIA FOR MEASUREMENT DATA ... 3-4

3.2.1 Special Training Requirements/Certification ....................................... 3-6

3.2.2 Training Documentation and Records ................................................ 3-8

3.3 MEASUREMENT/DATA ACQUISITION ..................................................... 3-8

3.3.1 Sampling Methods and Requirements ............................................ 3-8

3.3.2 Sample Management.......................................................................... 3-9

3.3.3 Analytical Method Requirements ..................................................... 3-10

3.3.4 Radiological Surveys ..................................................................... $3-10$

3.3.5 Industrial Hygiene Surveys .............................................................. 3-10

3.3.6 Quality Control Requirements .......................................................... 3-10

3.3.7 Instrument/Equipment Testing Inspection, and Maintenance

Requirements ................................................................................ 3-12

3.3.8 Instrument Calibration Frequency .................................................... 3-12

3.4 DATA QUALITY ASSESSMENT......................................................... 3-12

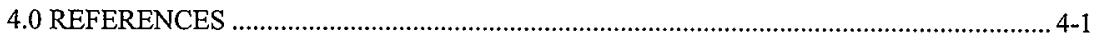

\section{APPENDICES}

A RADIOACTIVE AIR MONITORING PLAN FOR CONTROLLING AND MONITORING EMISSIONS FROM VENTING, SAMPLING AND PURGING UNDERGROUND STORAGE TANK 241-Z-361 …………...................................... A-i

B NON-RADIOACTIVE AIR MONITORING PLAN FOR CONTROLLING AND MONITORING EMISSIONS FROM VENTING, SAMPLING AND PURGING UNDERGROUND STORAGE TANK 241-Z-361 …............................................ B-i

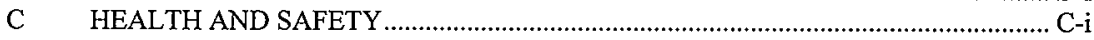

\section{FIGURES}

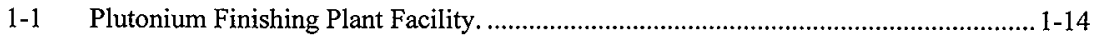

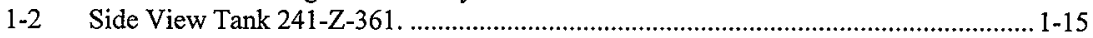

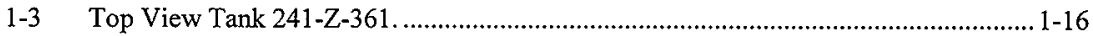

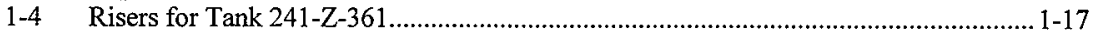

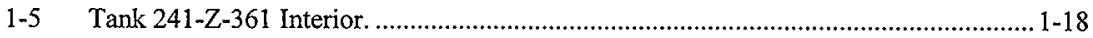

2-1 Sample Equipment Configuration Including Breather Filter......................................2-13

\section{TABLES}

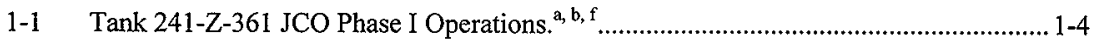

1-2 Typical Low-Salt Aqueous Process Streams in the Plutonium Finishing Plant (Circa 1969). ..................................................................................................... 1-6

1-3 Sample Descriptions for 1977 Sludge Sample......................................................... 1-7

1-4 Component Concentrations in Air Dried Tank 241-Z-361 Solids.................................... 1-7 
1-5 Known and Probable Components of 241-Z-361 Tank Sludge.................................1-8

1-6 Information and Data Inputs. ............................................................................. 1-11

1-7 Analytical Action/Decision Limits, Estimated Quantitation Limits, and Precision Criteria. $1-12$

2-1 List of Samples and Activities for the NEVS System. ..............................................2-2

2-2 Chemical and Radiological Analytical Requirements. ................................................2-9

2-3 Final Vapor Report Contents (Format VI) ............................................................ 2-10

3-1 Tank Vapor Sampling Project Key Personnel List. ......................................................... 3-2

3-2 Radiological Entry Requirements (Summary Table).................................................... 3-7

3-3 Entry Hazardous Worker Training and Medical Requirements. ................................... 3-8 


\section{TERMS}

ARAR

BWHC

CAM

CERCLA

CGM

$\mathrm{CPO}$

DOE

DOE-RL

DQO

EPA

EQL

ERDF

GC/MS

GC/TCD

HEPA

HPT

IC

IMUST

JCO

LFL

MDL

NEPA

NEVS

NHC

PFP

PRC

QA

QAPP

QC

RCRA

SAP

SAS

TAP

TRU

TWRS

USQ

WIPP

WMFSH

WSCF applicable or relevant and appropriate requirement

BW Hanford Corporation

continuous air monitor

Comprehensive Environmental Response, Compensation, and Liability Act of 1980

combustible gas meter

Characterization Program Operations

U.S. Department of Energy

U.S. Department of Energy, Richland Operations Office

Data Quality Objectives

U.S. Environmental Protection Agency

estimated quantitation limits

Environmental Restoration Disposal Facility

gas chromatography/mass spectroscopy

gas chromatography/thermal conductivity detection

high-efficiency particulate air (filter)

Health Physics Technician

ion chromatography

inactive miscellaneous underground storage tank

Justification for Continued Operation

lower flammability limit

method detection limit

National Environmental Policy Act

non-electrical vapor sampling

Numatec Hanford Corporation

Plutonium Finishing Plant

plant review committee

quality assurance

Quality Assurance Project Plan

quality control

Resource Conservation and Recovery Act of 1976

Sampling and Analysis Plan

Special Analytical Support

toxic air pollutant

transuranic

Tank Waste Remediation System

Unreviewed Safety Question

Waste Isolation Pilot Plant

Waste Management Federal Services Hanford

Waste Sampling Characterization Facility 


\section{TANK 241-Z-361 VAPOR SAMPLING AND ANALYSIS PLAN}

\subsection{INTRODUCTION}

Tank 241-Z-361 is identified in the Hanford Federal Facility Agreement and Consent Order (commonly referred to as the Tri-Party Agreement), Appendix C, (Ecology et al. 1994) as a unit to be remediated under the authority of the Comprehensive Environmental Response, Compensation, and Liability Act of 1980 (CERCLA). As such, the U.S. Environmental Protection Agency will serve as the lead regulatory agency for remediation of this tank under the CERCLA process. At the time this unit was identified as a CERCLA site under the Tri-Party Agreement, it was placed within the 200-ZP-2 Operable Unit. In 1997, The Tri-parties redefined 200 Area Operable Units into waste groupings (Waste Site Grouping for 200 Areas Soils Investigations [DOE-RL 1992 and 1997]). A waste group contains waste sites that share similarities in geological conditions, function, and types of waste received. Tank $241-Z-361$ is identified within the CERCLA Plutonium/Organic-rich Process Condensate/Process Waste Group (DOE-RL 1992).

The Plutonium/Organic-rich Process Condensate/Process Waste Group has been prioritized for remediation beginning in the year 2004. Results of Tank 216-Z-361 sampling and analysis described in this Sampling and Analysis Plan (SAP) and in the SAP for sludge sampling (to be developed) will determine whether expedited response actions are required before 2004 because of the hazards associated with tank contents. Should data conclude that remediation of this tank should occur earlier than is planned for the other sites in the waste group, it is likely that removal alternatives will be analyzed in a separate Engineering Evaluation/Cost Analysis (EE/CA). Removal actions would proceed after the U.S. Environmental Protection Agency (EPA) signs an Action Memorandum describing the selected removal alternative for Tank 216-Z-361. If the data conclude that there is no immediate threat to human health and the environment from this tank, remedial actions for the tank will be defined in a feasibility study for the entire waste group.

Tank 241-Z-361 is an inactive reinforced-concrete underground tank within the fenced area of the Plutonium Finishing Plant (PFP) at the Hanford Nuclear Reservation near Richland, Washington (DOE-RL 1992). The tank is located approximately $240 \mathrm{ft}$ south of Building 236-Z (Figure 1-1).

Tank 241-Z-361 served as a primary solids settling tank for low-salt liquid waste from the 234-5Z, 236-Z, and 242-Z buildings. The supernate from Tank 241-Z-361 was routed to the 216-Z-1A tile field and the 216-Z-1, $-2,-3$, and -12 cribs for disposal to ground (DOE-RL 1992). The tank was taken out of service in 1973, supernate was removed in 1975 and the tank was sealed in 1985. Tank contents are expected to contain constituents from nearly all PFP processes used during this period, and will be dominated by the insoluble components of effluents from Buildings 234-5Z, 236-Z and 232-Z. 
The 1997 PFP chemical hazard assessment (FDNW 1997), identified potential hazards associated with the tank which were not completely evaluated and controlled within the current PFP authorization basis. These hazards included potential flammable gas accumulation within the tank since it was sealed in 1985, potential for inadvertent criticality, and potential structural integrity degradation due to corrosion of the concrete and reinforcing bars. An Unreviewed Safety Question (USQ) was declared in late 1997 (Wagoner 1997) and interim safety controls were imposed which restrict spark- and flame-producing activities in the vicinity of the tank and prevent traffic over the tank.

The 241-Z-361 Tank Justification for Continued Operations (JCO) provides the safety assessment of potential hazards and accident scenarios. It also authorizes a series of activities to define the actual hazards associated with the tank. Phase I provides a safety basis for and describes the operations and controls for opening the tank safely, resolving structural integrity and flammable gas issues, and generally assessing the condition of the tank contents. Phase II will consist of actual sludge sampling and characterization. Together, Phase I and Phase II JCO authorize activities that will generate data and observations necessary to support closure of the USQ and evaluate ultimate remediation approaches. Additional information explaining the hazard assessment, including potential for criticality, is provided in the JCO (PHMC 1998).

This Sampling and Analysis Plan (SAP) describes a subset of Phase I JCO activities: initial opening of the first sealed riser, venting excess pressure (if any), installation of a breather filter on the riser, sampling the interior tank vapor, chemical analysis of the collected vapor samples, and videography of the interior of the tank. Phase II activities (waste sampling and analysis and any other investigative activity which would require movement of more than $1 \mathrm{yd}^{3}\left[0.914 \mathrm{~m}^{3}\right]$ of soil) will be covered under a separate SAP.

In accordance with U.S. Department of Energy (DOE) Orders and National Environmental Policy Act of 1969 (NEPA) policy, Comprehensive Environmental Response, Compensation and Liability Act of 1980 (CERCLA) documents incorporate NEPA values, such as analysis of cumulative, offsite, ecological, and socioeconomic impacts, to the extent practicable.

Cumulative impacts are not expected to occur from the activities described in this SAP because potential releases from sampling efforts are expected to be minimal. Waste generated from activities is also expected to be minimal. Offsite impacts include impacts to the public or the environment due to releases of contaminants resulting from an activity. No offsite impacts would be expected from the activities described in this SAP. Any offsite facility that could potentially be used to dispose of waste would be required to meet all standards for protection of the public and the environment.

The activities described in this SAP would not be expected to significantly affect existing natural or cultural resources. Socioeconomic impacts would also be minimal. The work force required for these activities would be small and would be drawn from existing work force resources.

The activities described in this SAP will result in some tank vapor being released. Appendices A and $\mathrm{B}$ describe the radiological and non-radiological air emissions estimates and resulting emission controls. This is provided in accordance with CERCLA requirements as an applicable 
or relevant and appropriate requirement (ARAR). To determine the best available control technologies, assure compliance with applicable Federal and State substantive emissions and design standards, and establish the appropriate monitoring and notification requirement (i.e., appropriate documentation to demonstrate compliance) for radioactive and non-radioactive air emissions, Appendices A and B are in the format of a Clean Air Act notice of construction application. Appendix $\mathrm{C}$ is the Project Health and Safety Plan.

\subsection{SCOPE}

The Tank 241-Z-361 JCO (PHMC 1998) describes the first part of a phased authorization to conduct activities to address hazards posed by this tank and to characterize it in preparation for remediation. These activities are defined as JCO Phase I activities. This SAP addresses a subset of these activities that are integral to the tank vapor sampling and analysis task. Table 1-1 lists the JCO tasks/operations within Phase I. This list includes actual vapor sampling, which is the primary focus of this SAP. Seven other activities are considered "associated" with the vapor sampling and are also described in this SAP, but in less detail. Another SAP will be written at a later date to include sludge sampling.

Incidental movement of no more than $1 \mathrm{yd}^{3}\left(0.914 \mathrm{~m}^{3}\right)$ of gravel/soil may be necessary to level equipment and place safety and radiation controlled area signs. Fugitive and diffuse emissions associated with these limited soil movement activities will be monitored by local area monitors and field radiological control technicians and Industrial Hygiene personnel. Detailed information is included in Appendices A and B.

\subsection{TANK 241-Z-361 DESCRIPTION}

Tank 241-Z-361 is a rectangular underground structure, constructed of reinforced concrete, and located near the east end of the south fence line of the PFP between Building 241-Z and the retention basin, $73.15 \mathrm{~m}$ ( $240 \mathrm{ft}$ ) south of 236-Z (DOE-RL 1992). The tank is $7.92 \mathrm{~m}$ (26 ft) long and $3.96 \mathrm{~m}(13 \mathrm{ft})$ wide and varies in depth between $5.18 \mathrm{~m}(17 \mathrm{ft})$ deep at the inlet (north end) and $5.49 \mathrm{~m}(18 \mathrm{ft})$ deep at the outlet (south end). The tank base is $22.86 \mathrm{~cm}(9$ in.) thick with grout and waterproofing added for a total thickness of $30.48 \mathrm{~cm}$ (12 in.). All walls are $30.48 \mathrm{~cm}(12 \mathrm{in}$.) thick and the roof is $25.40 \mathrm{~cm}$ (10 in.) thick. The top of the tank was sealed with $0.635 \mathrm{~cm}(1 / 4 \mathrm{in}$.) mastic and approximately $10.16 \mathrm{~cm}$ (4 in.) of concrete were poured over the mastic with $5.08 \mathrm{~cm}$ by $5.08 \mathrm{~cm}$ ( 2 in. by 2 in.) 14 gauge reinforcement mesh. The elevation of the top of the tank is $204.83 \mathrm{~m} 15.24 \mathrm{~cm}(672 \mathrm{ft} 6 \mathrm{in}$.) (Figure 1-2). Grade level elevation is $205.44 \mathrm{~m} 15.24 \mathrm{~cm}(674 \mathrm{ft} 6 \mathrm{in}$.$) .$

The interior of the tank was lined with $0.9525 \mathrm{~cm} \mathrm{(3/8} \mathrm{in.)} \mathrm{carbon} \mathrm{steel} \mathrm{on} \mathrm{the} \mathrm{bottom} \mathrm{and} \mathrm{up} \mathrm{the}$ sides to within $15.24 \mathrm{~cm}(6 \mathrm{in}$.) of the roof. A protective coating was placed between the liner and the concrete as a corrosion barrier. Two $15.24 \mathrm{~cm}$ (6-in.) stainless-steel pipes lead into the tank (from the retention basin and 241-Z) at the north end of the tank and one $20.32 \mathrm{~cm}(8 \mathrm{in}$.) stainless-steel pipe forms the discharge at the south end of the tank. Baffle boxes were installed 
around the inlet and discharge pipes, and attached to the liner. The bottom of the inlet piping is elevation $669^{\prime}$ and the bottom of the discharge pipe is elevation $668^{\prime}$.

Table 1-1. Tank 241-Z-361 JCO Phase I Operations. ${ }^{\text {a, b, f }}$

\begin{tabular}{|l|l|}
\hline 1. & $\begin{array}{l}\text { Civil Survey and Load Test - Check to Determine Ground Level and Soil Depth and Verify Capability } \\
\text { of Tank to Support Personnel and Equipment for Riser Opening }\end{array}$ \\
\hline 2. & $\begin{array}{l}\text { Ground Penetrating Radar (Optional) - Determine Outline of Tank Top and Location of Buried Lines } \\
\text { near Tank }\end{array}$ \\
\hline 3. & Excavate Small Area next to Tank to Permit Ultrasound Wall and Roof Check (Optional) \\
\hline 4. & Perform Ultrasound Check - Attempt to Verify Tank Wall and Top Integrity (Optional) \\
\hline 5. & Install People Bridge (Optional Depending on Tank Load Test Results) \\
\hline $6 .^{\text {d }}$ & Radiological Survey of Risers (Activity Preliminary to Any Further Actions to Enter Tank) \\
\hline $6 . A$ & $\begin{array}{l}\text { External Gamma and Neutron Scans (Optional) - Attempt to Determine If Criticality Event Has } \\
\text { Occurred }\end{array}$ \\
\hline $7 .^{d}$ & $\begin{array}{l}\text { Inspect Riser [Procedure Item - Riser Prep] (It Is Assumed That a People Bridge Is in Place or it Has } \\
\text { Been Determined That One Is Not Required for Access on the Tank Roof) }\end{array}$ \\
\hline $8 .{ }^{d}$ & Open Riser - Replace Bolts, Install Glovebag, Relieve Pressure, Remove Flange \\
\hline $9 .^{\mathrm{d}}$ & Install Breather Filter On Open Riser \\
\hline $9 . A^{\mathrm{d}}$ & $\begin{array}{l}\text { Purge Tank [This Is a Contingency and the Only Way Tank Can Be Accessed If Atmosphere Is } \\
\text { Determined to Be Flammable] }\end{array}$ \\
\hline $10^{\mathrm{d}}$ & Take Pictures/video Inside Tank (Requires Entry Through 8-inch Riser) \\
\hline $11^{\mathrm{c}, \mathrm{d}}$. & Perform Vapor Sampling (This Data Is for Characterization) \\
\hline 12. & $\begin{array}{l}\text { Take Hard Gamma/test for Mixed Fission Products (Optional) - Further Testing to Determine If } \\
\text { Criticality Has Occurred }\end{array}$ \\
\hline
\end{tabular}

Source: PHMC (1998).

${ }^{\mathrm{a}}$ Items $1,2,4,5,6 . \mathrm{A}$, and 12 are not described by this SAP.

${ }^{b}$ Activities in this table are not in chronological order.

'Item 11 is the primary activity described in this SAP.

Items $3,6,7,8,9,9 . \mathrm{A}, 10$ and 11 are activities integral to tank vapor sampling and are described in this SAP.

'Any excavation is done as a CERCLA activity. No more than $1 \mathrm{yd}^{3}\left(0.914 \mathrm{~m}^{3}\right)$ of soil is allowed to be moved without prior regulatory agreement.

${ }^{f}$ Criteria for performing optional activities will be provided in subsequent working documents.

The tank roof has three large penetrations and eight riser penetrations (Figures 1-3 and 1-4). A $0.91-\mathrm{m}(3-\mathrm{ft})$ manhole exists at the north end of the tank. A second manhole is centered near the south outside wall of the tank, and the third large penetration is a $1.22-\mathrm{m}$ (4-ft) diameter concrete plug in the geometric center of the tank roof. There are two $20.32-\mathrm{cm}(8-\mathrm{in}$.) risers, one $5.08-\mathrm{cm}$ (2-in.) riser, and one $7.62-\mathrm{cm}(3-i n$.$) riser built into the southwest corner of the tank, and one$ $7.62-\mathrm{cm}(3-\mathrm{in}$.) riser built into the northeast corner of the tank. One 15.24-cm (6-in.) riser penetration was installed through the concrete plug, and two $20.32-\mathrm{cm}$ (8-in.) riser penetrations were installed north of the center plug. All eight risers are capped or flanged closed and no equipment remains installed in the tank. 
One of the south end 20.32-cm ( 8 -in.) risers had a dry well installed, and it has since been removed or corroded away, as it is not visible in the photographs of the interior of the tank. The inlet and outlet pipes have been isolated and plugged or flanged $0.61 \mathrm{~m}(2 \mathrm{ft})$ from the outer wall of the tank. The reinforced concrete poured over the top of the tank has been removed over the two manholes and the tank was opened for sampling and photography in the mid 1970's. The manhole covers were subsequently reinstalled, covered with weather covers and buried. The

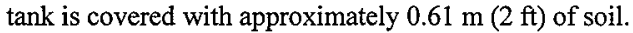

\subsection{TANK CONTENTS}

\subsubsection{General}

Tank 241-Z-361 was in service from 1949 to 1973 . Supernate was pumped from the tank and the tank was isolated in 1975. The tank was sealed in 1985 to prevent gas-phase communication with the surface. Photographs taken in 1975 show much of the tank's carbon steel liner appears to have dissolved through corrosion (Figure 1-5). The 1975 photographs also show some features which may be degradation of the concrete surface, however, the exposed concrete appears intact. The condition of the concrete below the waste surface could not be ascertained. Approximately $239 \mathrm{~cm}$ (94 in.) of sludge remains in the tank (about $75 \mathrm{~m}^{3}\left[82.05 \mathrm{yd}^{3}\right]$ ). Tank contents are expected to contain constituents from nearly all PFP processes used during this period. The sludge is expected to be dominated by the non-water-soluble components of effluents from Buildings 234-5Z, 236-Z, and 232-Z.

The effluents that flowed through the system included incinerator caustic off-gas scrubber solution, and liquid waste streams from the Plutonium Reclamation Facility, Waste Treatment Facility, and PFP laboratory. In addition to the drain lines from the process facilities, an unquantified (but large) volume of process water was discharged from retention basins to the cribs via Tank 241-Z-361.

\subsubsection{Historical Process Records}

Table 1-2 shows the process streams, volumes and plutonium content for the low-salt aqueous streams flowing through Tank 241-Z-361 in 1969. This is presented as a typical year and one in which all major processes were operating (i.e., PFP, Incinerator, Plutonium Reclamation Facility and Waste Treatment Facility) and contributing to the effluent.

Large amounts of water were flushed through Tank 241-Z-361 and the discharges to the tank were generally dilute. Therefore, any constituents that were soluble in water were likely to have been washed to the cribs, leaving water-insoluble solids. In addition, materials sent to Tank 241-Z-361 were steam-jetted. Compounds with low-boiling points and high vapor pressures would likely have been vaporized and released through system vents. Except for the laboratory-generated waste streams, there were no processes that discharged reactants reasonably capable of generating large exothermic reactions. The laboratory chemicals discharged would have been in small quantity and well diluted and, therefore, not likely to present a significant 
hazard. However, some organic materials used were heavier-than-water and may have settled in layers within the tank sludge. Until the sludge is sampled, the potential for organic or organicnitrate reactions, although very slim, cannot be completely excluded.

Table 1-2. Typical Low-Salt Aqueous Process Streams in the Plutonium Finishing Plant (Circa 1969).

\begin{tabular}{|l|l|l|r|r|r|}
\hline \multicolumn{1}{|c|}{ Stream } & \multicolumn{1}{|c|}{ Drain } & \multicolumn{1}{|c|}{ Source } & $\begin{array}{r}\text { Thousands of } \\
\text { Gallons/Year }\end{array}$ & $\begin{array}{r}\text { Plutonium } \\
\text { Grams/Year }\end{array}$ & $\begin{array}{c}\text { Chemical } \\
\text { Contaminant }\end{array}$ \\
\hline $\begin{array}{l}\text { Uncontaminated lab } \\
\text { wastes }\end{array}$ & $\mathrm{D}-4,5$ & $\begin{array}{l}\text { Cooling water } \\
\text { for equipment } \\
\text { in labs }\end{array}$ & 127 & 0 & None \\
\hline $\begin{array}{l}\text { Contaminated lab } \\
\text { wastes }\end{array}$ & $\mathrm{D}-4,5$ & Lab drains & 174 & $\begin{array}{l}\text { Miscellaneous lab } \\
\text { chemicals }\end{array}$ \\
\hline $\begin{array}{l}\text { Waste treatment } \\
\text { aqueous waste }\end{array}$ & D-6 & $\begin{array}{l}\text { lon exchange } \\
\text { process }\end{array}$ & 86 & $\begin{array}{l}\text { Principally Al, Ca, } \\
\text { Mg, nitrate }\end{array}$ \\
\hline $\begin{array}{l}\text { Incinerator scrubber } \\
\text { solution }\end{array}$ & D-6 & $\begin{array}{l}\text { Spent caustic } \\
\text { from scrubber }\end{array}$ & 600 & Considerable Na \\
\hline $\begin{array}{l}\text { Reclamation } \\
\text { condensate }\end{array}$ & D-6 & $\begin{array}{l}\text { Process } \\
\text { concentrators }\end{array}$ & 54 & 12 & Slight \\
\hline $\begin{array}{l}\text { Fluorinator off-gas } \\
\text { jet }\end{array}$ & D-6 & $\begin{array}{l}\text { Water for } \\
\text { vacuum jet }\end{array}$ & 1,906 & $\mathbf{8 7 2}$ & \\
\hline
\end{tabular}

Source: Jones (1997).

\subsubsection{Historical Characterization Data}

Tank 241-Z-361 was characterized in the mid-to-late 1970's as described in Dodd (1976) and Jones (1997). The main focus of that characterization was the plutonium content of the sludge, the distribution of plutonium, and the presence of various nuclear poisons. No vapor samples have been taken from Tank 241-Z-361.

The sludge was found to vary greatly in solids content, but to be on average $30 \%$ solid material with the rest being mostly water. The sludge was deposited in layers from the various operating campaigns, and exhibits considerable variability in consistency. Tables 1-3 and 1-4 portray the sludge appearance and non-radioactive content based upon core sampling. There is no indication of free organic layers which may provide significant vapor-phase organic compound concentrations.

The large volumes of water discharged through this tank should have washed away soluble components. Based on bench-scale tests, the addition of water to the tank would not dissolve the plutonium or other solids (Jones 1997). Dodd (1976) indicated the sludge samples were very difficult to dissolve, even in a solution of $12 \mathrm{M}$ nitric acid and $0.5 \mathrm{M}$ hydrofluoric acid. This demonstrates the highly insoluble nature of the residual tank solids. 
Based on processes that were known or suspected to have sent waste to 241-Z-361, the tank sludge may contain some or all of the components listed in Table 1-5.

Table 1-3. Sample Descriptions for 1977 Sludge Sample.

\begin{tabular}{|l|l|}
\hline & \multicolumn{1}{|c|}{ Sample Description } \\
\hline NW-1 & Dark brown -almost black - loose -wet \\
\hline NW-2 & Color of sample 1 - thicker \\
\hline NW-3 & Small amount of free liquid on top color of sample 1 - thicker than 2 \\
\hline NW-4 & Dark brown -lighter than 2- thinner \\
\hline NW-5 & Lighter color than 4 - very watery - thin soup \\
\hline NW-6 & Thicker than 5 - lighter color than 5 - gritty - sandy \\
\hline NW-7 & Thicker than 6 - dark tan color - pasty, creamy consistency \\
\hline NW-8 & Same as 7 except lighter color \\
\hline NW-9 & Free liquid on top - only slightly darker color than 8- same consistency \\
\hline NW-10 & Same as 9 \\
\hline NW-11 & Tan-brown same as 10 - slightly darker \\
\hline NW-12 & Lot of liquid on top. Lt. brown darker than the five samples above \\
\hline
\end{tabular}

Source: Lipke et al. (1997) and JCO (PHMC 1998).

Table 1-4. Component Concentrations in Air Dried Tank 241-Z-361 Solids.

\begin{tabular}{|l|c|c|c|c|}
\hline \multirow{2}{*}{ Component } & \multirow{2}{*}{$\begin{array}{c}\text { Northeast Core } \\
(\mathrm{g} / \mathrm{L})\end{array}$} & $\begin{array}{c}\text { Southwest Core } \\
(\mathrm{g} / \mathrm{L})\end{array}$ & \multicolumn{2}{c|}{$\begin{array}{c}\text { Center Manhole Bottle } \\
(\mathrm{g} / \mathrm{L})\end{array}$} \\
\cline { 3 - 5 } & 71.8 & 304.0 & Sample \#8 & Sample \#9 \\
\hline Aluminum & 345.0 & 460.0 & 322.4 & 290.3 \\
\hline Calcium & $<3.8$ & $<3.4$ & $<0.4$ & $0.9 ?^{*}$ \\
\hline Cadmium & 230.9 & 562.2 & 59.0 & 74.0 \\
\hline Iron & 18.6 & 40.5 & 6.3 & 200.4 \\
\hline Sodium & 10.5 & 10.4 & 4.4 & 8.3 \\
\hline Silicon & 20. & 200. & --- & $\cdots$ \\
\hline Oxygen & 0.6 & 60. & -- & $\cdots$ \\
\hline Hydrogen & 46. & 87.2 & $\cdots$ & $\cdots$ \\
\hline Carbon & -- & 34.2 & $\cdots$ & $\cdots$ \\
\hline Chloride & -- & 3.9 & $\cdots$ & $\cdots$ \\
\hline Fluoride & & & $-\cdots$ \\
\hline
\end{tabular}

Source: Lipke et al. (1997) and JCO (PHMC 1998).

*Documented in the JCO with "?". 
Table 1-5. Known and Probable Components of 241-Z-361 Tank Sludge.

\begin{tabular}{|c|c|c|}
\hline Type of Component & Component & Probable Source \\
\hline \multirow[t]{5}{*}{ Known metals } & $\mathrm{Al}$ & Waste treatment \\
\hline & $\mathrm{Na}$ & Incinerator off-gas treatment \\
\hline & $\mathrm{Ca}$ & Waste treatment \\
\hline & $\mathrm{Si}$ & Incinerator off-gas treatment \\
\hline & $\mathrm{Cd}$ & Most likely an analytical artifact \\
\hline \multirow[t]{5}{*}{ Known non-metals } & $\mathrm{F}^{-}$ & Hydrogen fluorinator \\
\hline & $\mathrm{Cl}^{-}$ & Waste treatment \\
\hline & $\mathrm{C}$ (organic or total?) & Incinerator off-gas treatment \\
\hline & $\mathrm{H}_{2} \mathrm{O}$ & All \\
\hline & $\mathrm{H}^{+}$ & All \\
\hline \multirow[t]{6}{*}{ Probable metals } & $\mathrm{Pb}$ & Incinerator off-gas treatment \\
\hline & $\mathrm{Mg}$ & Waste treatment \\
\hline & $\mathrm{Mn}$ & Waste Treatment \\
\hline & $\mathrm{Cr}$ & Corrosion of SS equipment \\
\hline & $\mathrm{Ni}$ & Corrosion of SS equipment \\
\hline & $\mathrm{Ag}$ & Lab film processing \\
\hline \multirow[t]{5}{*}{ Probable non-metals } & $\mathrm{NO}_{3}^{-}$ & Waste treatment \\
\hline & $\mathrm{NO}_{2}^{-}$ & Radiolysis of $\mathrm{NO}_{3}{ }^{-}$ \\
\hline & $\mathrm{SO}_{4}{ }^{2-}$ & Waste treatment \\
\hline & $\mathrm{PO}_{4}^{3-}$ & Degradation of TBP \\
\hline & $\mathrm{CO}_{3}{ }^{2-}$ & Incinerator off-gas treatment \\
\hline \multirow[t]{12}{*}{ Probable organics } & $\mathrm{CCl}_{4}$ & Waste process \\
\hline & DBBP & Waste treatment \\
\hline & TBP & Waste treatment \\
\hline & DBP & Degradation of TBP \\
\hline & MBP & Degradation of TBP \\
\hline & Butanol & Degradation of $T B P$ \\
\hline & Urea & Incinerator off-gas treatment \\
\hline & Lard oil (Triolein) & Waste treatment \\
\hline & Oxalic acid & Waste treatment \\
\hline & Acetic acid & Incinerator off-gas treatment \\
\hline & Benzene & Incinerator off-gas treatment \\
\hline & Phthalic acid & Incinerator off-gas treatment \\
\hline \multirow[t]{3}{*}{ Known radionuclides } & $\mathrm{Pu}$ & All \\
\hline & $\mathrm{Am}$ & Decay of $\mathrm{Pu}^{241}$ \\
\hline & $\mathrm{U}$ & Waste treatment \\
\hline
\end{tabular}

Source: Jones (1997).

The tank is believed to contain between 26 and $75 \mathrm{Kg}$ of plutonium (Freeman-Pollard 1994). Both volume discharge records and limited sludge sampling data strongly suggest the plutonium was distributed in relatively simple layers, with plutonium concentrations varying only within a factor of 2 from the mean of $0.4 \mathrm{~g} / \mathrm{L}$ ( $29 \mathrm{~kg}$ total inventory). A 1997 criticality study concluded that although the plutonium inventory is potentially sufficient to generate a criticality, its distribution within the sludge makes an inadvertent criticality extremely unlikely (Lipke et al. 1997). 
Little is known regarding the routine acidity of the wastes sent to the settling tank, other than the general operations guidance that the waste water was to be neutralized before transfer into tank 241-Z-361. In March 1975, the $\mathrm{pH}$ of one sample from tank sludge/solids was measured at 4.0. The corroded carbon steel liner also indicates that some wastes were not completely neutralized or the acidic flushes of Tank D-7 caused a low tank pH, or both. Likewise, while some organic materials have likely entered the tank, total carbon was found in only a few samples, and then at concentrations of about $1 \%$. Only one sample exhibited a higher concentration (6\%). The carbon could be from fly ash in the incinerator scrubber solution, carbonate from neutralization and absorption into caustic solution, or from organic compounds. No separate organic phase has been identified in the tank.

\subsection{STATEMENT OF THE PROBLEM}

The ultimate goal for the overall Tank 241-Z-361 Program is to minimize safety, safeguards, and environmental issues associated with the tank by removing/stabilizing the tank contents and performing final remedial activities on the tank. Before sludge sampling can occur and remedial actions defined and accomplished, the tank must be vented, the vapor space sampled, and the tank interior photographed.

The Tank 241-Z-361 vapor characterization data quality objectives (DQO) (Field and Banning 1998) defines the project problem as:

Characterize the Tank 241-Z-361 headspace vapors and assess the tank's structural integrity to resolve safety and environmental issues in anticipation of tank sludge sampling. ${ }^{1}$

Specific questions include:

- What specific off-gas controls will be required to meet applicable environmental (and site safety) regulations during tank core sampling?

- What controls on headspace vapors are needed to ensure worker safety during core sampling and dispositioning of the waste?

- What, if any, engineering structures (e.g., truck ramps or bridges) are required during core sampling to withstand the load applied by the tank sampling truck?

\subsection{DECISIONS}

Results of the vapor sample analysis and videography are intended to supply information that would support the design and safe accomplishment of future sludge core-sampling activities while:

\footnotetext{
${ }^{1}$ Structural integrity data collection is addressed in the JCO (PHMC 1998).
} 
- air emission regulatory requirements are met;

- air emission, flammable gas and toxicity safety requirements are met; and,

- the tank structure can withstand loads applied during waste sampling and waste disposition.

Table 1-7 lists the action limits based on limits from WAC 173-460 and based on TWRS tank safety criteria. The following lists the results of exceeding these limits:

- If air emissions (toxic air pollutants) requirements are exceeded, additional precautions (i.e., filtering or treatment of vapor) may be required before core sampling or disposition of the waste can occur.

- If, based on engineering judgement, tank videos and/or photographs indicate the tank steel and concrete may have degraded such that the structure is weakened, then an evaluation will be made to determine if an ultrasound is required and if a bridge should be constructed (as opposed to using existing truck ramps) before the waste is core sampled.

No action levels were identified for tank structural characterization. However, after tank photographs and/or videos are obtained, an assessment will be made by project engineers to determine whether ultrasonic characterization is required and if truck ramps or a bridge are needed to support the structural loads that will be applied to the tank by the core sampling truck during Phase II of the characterization program.

\subsection{REQUIRED DATA}

The Tank 241-Z-361 Vapor Characterization DQO (Field and Banning 1998) defines the type, quantity and quality of data needed to satisfy the objectives of the Vapor Sampling project. Tables 1-6 and 1-7 include detailed lists of analytes for which vapor analyses are required, action levels for decision making, measurement methods, estimated quantitation limits (EQLs) and precision requirements.

Action limits for individual constituents are equivalent to the conservative concentrations assumed for the emissions calculations (see Appendix B). Exceedance of these limits would initiate re-calculation to determine whether the actual emissions exceed any regulatory reporting triggers. The lower flammability limit (LFL) initiates additional controls and/or corrective measures in the field.

No quantitative requirements are applicable to photographic/videographic examination. Qualitatively, the videography should be complete enough, and of appropriate clarity and scale, to enable visual evaluation of the structure of the entire tank interior surfaces from roof to the sludge level, and to record the visual condition of the tank sludge surface. 


\subsection{DATA UNCERTAINTY REQUIREMENTS}

No historical vapor sample information is available for this tank. Consequently, uncertainty estimates to provide a statistical basis for the number of samples needed are not available. It is assumed due to the extensive time the tank has remained sealed and undisturbed, the headspace vapor composition will be uniform throughout the tank. As a result, one vapor sample set will be obtained from one riser. No further statistical analysis of uncertainty parameters will be performed.

Table 1-6. Information and Data Inputs.

\begin{tabular}{|c|c|c|}
\hline Input & Reason for Including & $\begin{array}{c}\text { Is Information Currently } \\
\text { Available? }\end{array}$ \\
\hline $\begin{array}{l}\mathrm{CCl}_{4}, \mathrm{NO}_{x} \text {, Tri-butyl phosphate, Di- } \\
\text { butyl phosphate, acetic acid, } \\
\text { benzene, n-butanol }\end{array}$ & $\begin{array}{l}\text { Air Emissions (TAPs) Regulations } \\
\text { (WAC 173-460) }\end{array}$ & No data available. \\
\hline $\begin{array}{l}\text { Vapor space: LFL, } \mathrm{N}_{2} \mathrm{O}, \mathrm{O}_{2}, \mathrm{NH}_{3} \text {, } \\
\mathrm{CH}_{4}, \mathrm{H}_{2}\end{array}$ & $\begin{array}{l}\text { Flammable gas safety issues, vapor } \\
\text { sample release to the laboratory }\end{array}$ & No data available. \\
\hline Benzene, $\mathrm{CCl}_{4}, \mathrm{NO}_{2}, \mathrm{NH}_{3}$ & Toxicity safety issues & No data available. \\
\hline Total beta, total alpha & Radioactivity safety issues & $\begin{array}{l}\text { No current data available. No vapor } \\
\text { data available }\end{array}$ \\
\hline $\begin{array}{l}\text { Tank photographs and/or videos: all } \\
\text { tank wall surfaces above the current } \\
\text { waste level, ceiling surface, interior } \\
\text { surface of risers to be sampled and } \\
\text { concrete ceiling at the riser/concrete } \\
\text { interfaces. Evidence of crumbling } \\
\text { or spalling should be photographed/ } \\
\text { video'd "close-up." }\end{array}$ & Structural stability safety issues & $\begin{array}{l}1975 \text { photographs available. New } \\
\text { photographs/videos are needed. }\end{array}$ \\
\hline
\end{tabular}

Source: Field and Banning (1998).

$\mathrm{TAP}=$ toxic air pollutants.

Uncertainty questions are not applicable to tank structure assessments. Calculations/assessments will be updated and added to existing data (including load-test results) based on videography to estimate the tank structure load capacity. The load capacity must provide a safety factor of at least 2 over the load of the sample truck (Field and Banning 1998). If the calculated load capacity is less, engineering controls (e.g., truck ramps or bridge structures) will be designed and constructed before core sampling.

\subsection{VAPOR SAMPLING AND VIDEOGRAPHY PROJECT DESIGN}

The project objectives of generating data to help resolve flammable gas, tank structural integrity and potential chemical emissions associated with future sludge sampling will be accomplished as a subset of JCO-authorized activities, through the following design. The activities required to accomplish this design are described in greater detail in Section 2.0. 
- Open tank riser. The riser flange will be opened in a controlled manner, within glove-bag containment, allowing any tank pressure to be released. Controls will be in place to limit gas flow and to purge the glove-bag containment if the \%LFL exceeds $25 \%$.

- Install breather filter. A breather filter will be installed on the riser to permit passive ventilation of the tank. The filter assembly will include a vapor sampling port. Glovebag containment will be kept below $25 \%$ LFL by either passive or active (inert gas purging) means throughout the filter-installation activities.

- Take vapor samples. Vapor samples will be taken via the breather filter vapor sampling port using $\mathrm{SUMMA}^{\circledR}$ canisters, sorbent tubes, and sorbent trains from one riser.

Table 1-7. Analytical Action/Decision Limits, Estimated Quantitation Limits, and Precision Criteria.

\begin{tabular}{|c|c|c|c|c|}
\hline $\begin{array}{l}\text { Analyte from } \\
\text { Measurement }\end{array}$ & $\begin{array}{l}\text { Suggested Measurement } \\
\text { Method }\end{array}$ & Action Limit & $\begin{array}{c}\text { Estimated } \\
\text { Quantitation } \\
\text { Limit }\end{array}$ & $\begin{array}{l}\text { Precision } \\
\text { RPD (\%) }\end{array}$ \\
\hline \multicolumn{5}{|c|}{ Vapor Sampling } \\
\hline $\mathrm{CCl}_{4}$ & GC/MS & $4,400 p p m v^{1,2}$ & $5 p p b v$ & \pm 25 \\
\hline Acetic acid & $I C$ & $57.4 p p b v$ & $50 p p b v$ & \pm 25 \\
\hline Benzene & $\mathrm{GC} / \mathrm{MS}$ & 324 ppmv $^{1}$ & $5 p p b v$ & \pm 25 \\
\hline n-Butanol & GC/MS & 27,800 ppbv $^{1}$ & $5 p p b v$ & \pm 25 \\
\hline Percent of LFL & CGA (sniff) & $25 \%$ & $1 \%$ & \pm 25 \\
\hline Tri-butyl phosphate & GC/MS & $158 p p b v^{1}$ & $5 p p b v$ & \pm 25 \\
\hline Di-butyl phosphate & GC/MS & $4.48 p p b v^{1}$ & $5 p p b v$ & \pm 25 \\
\hline \multicolumn{5}{|c|}{ Samples Collected on Second Filter (Record Filter) } \\
\hline Alpha $^{3}$ & gas flow proportional counter & $2.18 E-4$ curies $^{9}$ & I microcurie & \pm 25 \\
\hline Beta $^{3}$ & gas flow proportional counter & $2.00 E-4$ curies $^{4}$ & 1 microcurie & \pm 25 \\
\hline Gamma $^{3}$ & gamma emission analysis & not applicable & 1 microcurie & \pm 25 \\
\hline
\end{tabular}

Source: Field and Banning (1998) (modified). Table entries in bold ifalics have been added or modified after completion of the DQO process and after interviewing SAS Laboratory personnel. EQLs remain well below action limits except for DBP. For $\mathrm{DBP}, \mathrm{EQL}$ will be the action limit.

'Action limits are concentrations used to estimate TAP emissions (see Appendix B). Exceedance of these limits will initiate recalculation of TAP emissions.

${ }^{2}$ The action limit is based on a reportable quantity (RQ) that assumes $10 \mathrm{lb}$ released in a 24-hr time period.

${ }^{3}$ See Appendix A, Attachment 2.

${ }^{4}$ If action limits for total alpha are exceeded, individual isotope quantitation of Am-241 and $\mathrm{Pu}-239 / 240$ may be performed. If the individual isotopes exceed limits, the exceedance shall be reported to DOE-RL and EPA.

$\mathrm{CGA}=$ combustible gas analyzer. $\mathrm{IC}=$ ion chromatography.

DQO = Data Quality Objective LFL $=$ lower flammability limit.

EQL $=$ estimated quantitation limit. $\quad$ SAS $=$ Numatec Hanford Company Special

GC/MS = gas chromatography/mass spectroscopy. . Analytical Support Organization.

$\mathrm{GC} / \mathrm{TCD}=$ gas chromatography/thermal conductivity detector. TAP = toxic air pollutant.

- Videotape tank interior. An additional riser will be opened to permit camera equipment to be lowered into the tank dome space. At the discretion of the field team, a second riser may be opened to insert lighting equipment. The interior tank and waste surfaces will be videotaped.

Section 2.0 provides additional detail of field activities. Section 3.0 provides details of quality assurance and laboratory measurements. 
Figure 1-1. Plutonium Finishing Plant Facility.

(transmitted in separate Word file: Figure 1-1) 
Figure 1-2. Side View Tank 241-Z-361.

(transmitted in separate Word file: Figure 1-2) 
Figure 1-3. Top View Tank 241-Z-361.

(transmitted in separate Word file: Figure 1-3) 
Figure 1-4. Risers for Tank 241-Z-361.

(transmitted in separate Word file: Figure 1-4) 
Figure 1-5. Tank 241-Z-361 Interior.

(transmitted in separate Word file: Figure 1-5) 


\subsection{FIELD ACTIVITIES}

Field activities identified to support the project objective of definition and/or resolution of tank pressurization safety issues, flammable gas safety issues, air monitoring regulatory and tank integrity safety requirements in anticipation of future sludge sampling and remedial activities consist of:

- Work Area and Riser Preparation

- Relief of Initial Tank Pressure

- Flammable Gas Mitigation

- Installation of Breather Filter

- Tank Vapor Sampling

- Laboratory Analysis of Vapor Samples

- Tank Interior Videography

- Work Area Cleanup.

\subsection{TASK OBJECTIVES}

Work area and riser preparation. Prepare the work area by removing physical obstructions, placarding and posting, and installation of the air containment (glovebag). Ensure the work area is safe and air emission and radiological/chemical contamination is controllable.

Relief of initial tank pressure. Break the seal of the tank at the selected riser in a manner that is controlled and safe.

Flammable gas mitigation. Reduce \%LFL to levels which meet the current tank controls for invasive activities. Maintain \%LFL at low levels during tank-invasive activities. This may be accomplished using passive or active (inert gas purge) means.

Installation of breather filter. Install a breather filter with an integral vapor sampling port on the riser. The resulting installation will be a permanent passive-venting system.

Tank vapor sampling. Collect representative samples of the tank head space for chemical analysis. Resulting data will be used to define air emissions and safety requirements for future tank sludge core sampling.

Laboratory Analysis of Tank Vapor Sample. Analyze collected samples for air toxics, other gases, and radiological parameters, meeting $\mathrm{DQO}$ requirements.

Tank interior videography. Collect videos of the tank interior to enable engineering evaluation of the physical condition of the tank and answer structural integrity issues. 
Work area cleanup. Return the area to original condition, close risers, remove waste, and restore original access control posting.

\subsection{WORK AREA AND RISER PREPARATION}

A number of site-preparation activities are required to prepare the tank for the SAP-controlled activities (Sections 2.3 through 2.7). Initial radiological and toxic vapor surveys of the risers will be performed before opening risers. If initial radiological surveys indicate the need, neutron and gamma measurements will be obtained from the exterior at one or more risers. Work limitations, if any, will be established for the remaining planned work as a result of the toxic, radiological dose, or contamination conditions identified.

The riser will be inspected and prepared for opening, including providing any required work enclosures and any required riser supports. This includes taking measurements or patterns for riser adapters, fabrication of any required hardware, staging adapter and filter assemblies at, or over, the riser, staging asbestos abatement and riser preparation tools, and all other qualified tools required to safely open the riser containing potentially flammable, contaminated, toxic, pressurized gas.

The bolts holding the riser flange will be replaced one at a time with bolts made of non-sparking materials. The flange will be clamped shut during bolt replacement. After the bolts have been replaced, a glovebag will be installed around the riser with high-efficiency particulate air (HEPA) filtration to control contamination upon tank opening. Inert gas will be staged to provide a purge for the glovebag and the tank riser if needed.

Figure 2-1 shows the equipment location and sampling tubes relative to the riser. The breather filter assembly will be supported above the riser and sealed to the glovebag before tank pressure is released.

\subsection{RELIEF OF INITIAL TANK PRESSURE}

Any pressure in the tank will then be relieved and the riser flange removed. The flange will be raised by slowly loosening the riser flange bolts in incremental steps. The flow rate will be controlled to prevent over-pressurization of the glovebag, damage to the HEPA filters, or ripping the glovebag due to high flow rates. To prevent excessive rates of tank venting, the tank will be vented through a small orifice. This orifice will be in a flow restricting band applied around the flange. The atmosphere in the glovebag will be continuously monitored while work is in progress. At any point, if the glovebag atmosphere reaches $25 \%$ of the LFL, an inert gas purge may be applied to the glovebag. Further flange removal work will be halted in the glovebag until the atmosphere is less than $25 \%$ of the LFL. Once the tank has completely vented to atmospheric pressure and a relief path has been verified, a non-sparking insert will be slid between the riser and the flange to prevent inadvertent contact between them. The flange will then be lifted off the riser. If needed, an inert purge will be applied to the tank riser volume via a hose to keep the glovebag containment and riser volume less than $25 \%$ of the LFL. 


\subsection{INSTALLATION OF BREATHER FILTER}

Asbestos abatement will be conducted, and the riser flange will be prepared to receive the breather filter adapter using non-sparking tools. The breather filter will be lowered onto the open riser using a tripod and cable for support. The filter adapter will have suitable provisions for purging the riser volume and sampling the tank atmosphere without the hazard of introducing potential ignition sources to the atmosphere. Figure 2-1 is a diagram of the breather filter assembly positioned over the tank riser before installation.

\subsection{TANK VAPOR SAMPLING}

The vapor sampling team will be staffed and managed by Numatec Hanford Special Analytical Support (SAS). SUMMA ${ }^{\circledR}$ canister, sorbent train, and particulate filter samples will be collected using procedure LO-080-400, "Vapor Sampling Using Non-Electrical Vapor Sampling (NEVS) System."

\subsubsection{Preparation of Sampling Containers}

All SUMMA ${ }^{\circledR}$ canisters, sorbent trains and particulate filters will be prepared for sampling by SAS in accordance with Procedures SAS-LO-080-406 (SUMMA ${ }^{\circledR}$ canisters), and SAS-LA-549402 (sorbent trains). Particulate filters are one-use items and are ready for use as received. SAS shall provide unique sample identification numbers on the sample containers. SAS shall prelabel all sample containers before taking them into the field.

\subsubsection{Vapor Sampling Activities}

Vapor samples will be collected through a Teflon ${ }^{\circledR}$ sampling tube which extends from the breather filter assembly down to roughly $0.30 \mathrm{~m}(1 \mathrm{ft})$ from the sludge surface. Sampling equipment will be connected to the sample tube via a Swage Lok ${ }^{\circledR}$ fitting (see Figure 2-1).

Table 2-1 shows the sequence of sampling activities for the NEVS system, along with sample collection times and flow rates. Cleanliness of the NEVS system shall be checked and verified in accordance with the NEVS procedure LO-080-400. Two ambient air SUMMA ${ }^{(1)}$ samples shall be taken as field and system blanks. A field blank will be taken directly into a SUMMA ${ }^{(B)}$ canister, upwind of the Tank 241-Z-361 sampling riser. A system blank will be collected by sampling ambient air through the entire length of the NEVS sample line.

Table 2-1 shows the collection of 26 discrete samples during the sampling event:

- five SUMMA ${ }^{\circledR}$ canisters (one ambient air field blank, one system blank, and three tank samples), and

- six sorbent trains (four tank samples, one field blank, and one trip blank). 
- eight TBP/DBP sorbent tubes (five tank samples, one field blank, one field blank spike, and one trip blank)

- seven acetic acid sorbent tubes (four tank samples, two field blanks, and one trip blank).

Table 2-1. List of Samples and Activities for the NEVS System.

\begin{tabular}{|c|c|c|c|c|}
\hline $\begin{array}{l}\text { Sample } \\
\text { Code }\end{array}$ & Sample/Activity Description & $\begin{array}{l}\text { Sampler Position } \\
\text { During Collection }\end{array}$ & $\begin{array}{l}\text { Gas Flow } \\
\text { Rate }\end{array}$ & $\begin{array}{l}\text { Sample } \\
\text { Duration }\end{array}$ \\
\hline 01 & Collect ambient air SUMMA ${ }^{b}$ sample & Upwind of $\operatorname{tank}$ & N/A & $1 \mathrm{~min}$ \\
\hline 02 & Collect an NEVS Ambient air blank & $\begin{array}{l}\text { Not connected to tank } \\
\text { riser port }\end{array}$ & N/A & $1 \mathrm{~min}$ \\
\hline 03 & Collect SUMMA & riser port & $\mathrm{N} / \mathrm{A}$ & $1 \mathrm{~min}$ \\
\hline 04 & Collect SUMMA $^{(k)}$ & riser port & N/A & $1 \mathrm{~min}$ \\
\hline 05 & Collect SUMMA $^{(B)}$ & riser port & N/A & $1 \mathrm{~min}$ \\
\hline 06 & Collect $\mathrm{NH}_{3} / \mathrm{NO}_{\mathrm{X}} / \mathrm{H}_{2} \mathrm{O}$ sorbent train & riser port & $200 \mathrm{~mL} / \mathrm{min}$ & $10 \mathrm{~min}$ \\
\hline 07 & Collect $\mathrm{NH}_{3} / \mathrm{NO}_{\mathrm{X}} / \mathrm{H}_{2} \mathrm{O}$ sorbent train & riser port & $200 \mathrm{~mL} / \mathrm{min}$ & $10 \mathrm{~min}$ \\
\hline 08 & Collect $\mathrm{NH}_{3} / \mathrm{NO}_{\mathrm{X}} / \mathrm{H}_{2} \mathrm{O}$ sorbent train & riser port & $200 \mathrm{~mL} / \mathrm{min}$ & $15 \mathrm{~min}$ \\
\hline 09 & Collect $\mathrm{NH}_{3} / \mathrm{NO}_{\mathrm{X}} / \mathrm{H}_{2} \mathrm{O}$ sorbent train & riser port & $200 \mathrm{~mL} / \mathrm{min}$ & $15 \mathrm{~min}$ \\
\hline 10 & Collect sorbent train field blank & $\begin{array}{l}\text { Not connected to tank } \\
\text { riser port }\end{array}$ & $0 \mathrm{~mL} / \mathrm{min}$ & \\
\hline 11 & Collect sorbent train trip blank & Train sealed & N/A & N/A \\
\hline 12 & Collect acetic acid sorbent tube & Riser port & $200 \mathrm{ml} / \mathrm{min}$ & $25 \mathrm{~min}$ \\
\hline 13 & Collect acetic acid sorbent tube & Riser port & $200 \mathrm{ml} / \mathrm{min}$ & $25 \mathrm{~min}$ \\
\hline 14 & Collect acetic acid sorbent tube & Riser port & $200 \mathrm{ml} / \mathrm{min}$ & $25 \mathrm{~min}$ \\
\hline 15 & Collect acetic acid sorbent tube & Riser port & $200 \mathrm{ml} / \mathrm{min}$ & $25 \mathrm{~min}$ \\
\hline 16 & Collect field blank sorbent tube & $\begin{array}{l}\text { Not connected to the } \\
\text { riser port }\end{array}$ & N/A & N/A \\
\hline 17 & Collect field blank sorbent tube & $\begin{array}{l}\text { Not connected to the } \\
\text { riser port }\end{array}$ & N/A & $\mathrm{N} / \mathrm{A}$ \\
\hline 18 & Collect trip blank sorbent tube & Sealed sorbent tube & N/A & N/A \\
\hline 19 & Collect TBP/DBP sorbent tube & Riser port & $500 \mathrm{ml} / \mathrm{min}$ & $50 \mathrm{~min}$ \\
\hline 20 & Collect TBP/DBP sorbent tube & Riser port & $500 \mathrm{ml} / \mathrm{min}$ & $50 \mathrm{~min}$ \\
\hline 21 & Collect TBP/DBP sorbent tube & Riser port & $500 \mathrm{ml} / \mathrm{min}$ & $50 \mathrm{~min}$ \\
\hline 22 & Collect TBP/DBP sorbent tube & Riser port & $500 \mathrm{ml} / \mathrm{min}$ & $50 \mathrm{~min}$ \\
\hline 23 & Collect TBP/DBP sorbent tube & Riser port & $500 \mathrm{ml} / \mathrm{min}$ & $50 \mathrm{~min}$ \\
\hline 24 & Coliect field blank sorbent tube & $\begin{array}{l}\text { Not connected to the } \\
\text { riser port }\end{array}$ & N/A & N/A \\
\hline 25 & Collect field blank spike sorbent tube & $\begin{array}{l}\text { Not connected to riser } \\
\text { port }\end{array}$ & $\mathrm{N} / \mathrm{A}$ & $\mathrm{N} / \mathrm{A}$ \\
\hline 26 & Collect trip blank sorbent tube & Sealed sorbent tube & N/A & $\mathrm{N} / \mathrm{A}$ \\
\hline $\begin{array}{l}\text { N/A } \\
\text { NEVS }\end{array}$ & $\begin{array}{l}=\text { not applicable. } \\
=\text { non-electrical vapor sampling. }\end{array}$ & & & \\
\hline
\end{tabular}




\subsubsection{Field Monitoring}

All field activities will be accomplished with continuous Health Physics and Industrial Hygiene support. Radiological monitoring of surfaces and workplace air will be performed using alpha and beta/gamma survey instruments, and continuous air monitors (CAMs) for workplace alpha contamination. No mixed fission products ever entered the Z-361 tank; nevertheless, radiological monitoring will include both alpha and beta/gamma.

Industrial Hygiene will monitor for \%LFL of glove-bag air, tank riser vapor space, and workplace air using a Combustible Gas Meter (CGM) such as the Industrial Scientific Corporation model LTX 310. The meter is calibrated against pentane. Per the manufacturer's guidance, a conversion table is used when measuring gases other than pentane/air. A multiplication factor of 0.5 is recommended for hydrogen/air mixtures. For conservatism and to avoid confusion in the field, the meter reading conversion is not applied. This results in a very conservative operation.

In addition to flammability monitoring, Draeger tubes will be used to monitor carbon tetrachloride vapor in the workplace. This will be performed because the calculated potential carbon tetrachloride emissions during the venting/sampling activities approach the WAC 173-460 maximum small-quantity emission threshold and potentially exceed the CERCLA reportable quantity of $10 \mathrm{lb}$ in a $24-\mathrm{hr}$ period (see Appendix B).

\subsubsection{Radiation Release and Screening}

Radiological screening of samples will be performed at two times during the sampling/analytical sequence. The first screening will be at the tank riser. Tank Waste Remediation System (TWRS) Characterization Project Radiological Control will release the SUMMA ${ }^{\circledR}$ canisters, sorbent tubes, sorbent trains, and particulate filters from the jobsite by direct measurement and smearing. Radiation and contamination surveys will be performed in accordance with HNF-IP0718, Section 6.1, "Release Surveys for Materials and Equipment."

The second evaluation will be the analysis of the particulate filters by Waste Sampling and Characterization Facility (WSCF) (or 222-S) for total alpha and total beta. The reason for the particulate filter radiological testing is to document that no particulate radioactivity was introduced into the sample train media. If the results meet the SAS Vapor Laboratory acceptance criteria, (less than $5 \mathrm{pCi} / \mathrm{g}$ alpha and less than $15 \mathrm{pCi} / \mathrm{g}$ beta-gamma), this will be evidence that the particulate filtration was effective and the sorbent train samples will be released to the SAS laboratory for analysis as non-radioactive material. If the filters exceed the limits, the samples will be allowed to decay for a few days to ensure that the source of contamination is indeed radon/daughters. When the radon/daughters have decayed, the sorbent train samples can be accepted into the SAS Laboratory for analysis. If the samples do not decay consistently with radon/daughter contamination, the TWRS Characterization Program will provide guidance for sample media handling (e.g., dispose and resample, label and treat as radioactive material, etc.). 
Analysis of the particulate filters will be performed by WSCF in accordance with LA-508-415. Alpha counts will be converted to $\mathrm{pCi} / \mathrm{g}$ by conservatively assuming the specific activity of ${ }^{241} \mathrm{Am}$. An appropriate assumption for beta-specific activity will be assigned at the time of analysis but will likely be the beta emission from ${ }^{137} \mathrm{Cs}$. All radiological screening results will be included in the final sampling/analysis report issued by SAS.

\subsubsection{Vapor Sampling Quality Control}

Vapor sampling is conducted in accordance with the Quality Assurance Project Plan for Sampling and Analysis of Waste Tank Headspace Vapors (Keller 1994) and includes duplicate samples, field and system blanks, and trip blank as shown in Table 2-1.

\subsubsection{Documentation}

All sampling activities shall be documented in controlled field logbooks or other controlled documentation packages, maintained by sampling personnel. This documentation includes:

- identification of tank and riser number and photographs of the sampling location,

- any observed anomalies, corresponding sample identification numbers, flow rates, pressures, temperatures and other operational parameters potentially affecting the sample,

- any conditions that the sampling team observes during the sampling event (e.g., odors, nearby activities, machinery, electrical anomalies, etc.),

- names and titles of personnel involved in the field activity and their responsibilities, and

- problems and procedural changes potentially affecting the validity of the sample.

SAS field logbooks are controlled LAP-92-400, "Logkeeping Practices."

\subsubsection{Modifications, Deviations, Changes, and Observations}

Any modifications made to, or deviations from, the prescribed procedures are documented in the project notebooks, laboratory reports and project records in accordance with the quality assurance/quality control (QA/QC) program and project documents referenced within this section. All such modifications, deviations, and observations will be noted and justified, as appropriate, in the final sample analytical reports.

Nonconforming sampling and analytical actions or omissions will be identified, controlled, reported, and dispositioned as required by Nonconforming Item Reporting and Control (PHMC 1997). 


\subsection{LABORATORY ANALYSIS OF TANK VAPOR SAMPLES}

\subsubsection{Sample Management}

Sample analysis will be performed by two laboratory organizations. SAS is the primary analytical laboratory and will perform gas chromatography/mass spectroscopy (GC/MS), GC/thermal conductivity detection (TCD), and ion chromatography (IC) methods at their vapor laboratory in the 600 Area Weather Station Complex. The particulate filters will be analyzed for total alpha and total beta by the WSCF laboratory. The 222-S Laboratory will be a back-up to WSCF in case WSCF cannot perform the analysis.

One of the three SUMMA ${ }^{\circledR}$ canisters will be archived at the SAS laboratory without being analyzed. This canister will be retained in the event that additional vapor is necessary for future testing. This archive sample will be controlled in accordance with custody procedure LO-090450 for a maximum of 30 days from the issuance of the final data report, or until directed by the Z-361 Characterization Manager to dispose.

In the event that there is insufficient vapor volume in the remaining two SUMMA ${ }^{\circledR}$ canisters to perform all the requested analyses, the archive canister will be submitted for analysis. If this is also insufficient, the Tank 241-Z-361 Project Manager will be notified and analytical priorities will be defined for the limited sample volume.

\subsubsection{Chemical and Radiological Analysis}

Vapor samples collected from Tank 241-Z-361 will be analyzed for selected compounds as shown in Table 2-2.

\subsubsection{Laboratory Analytical Quality Control}

Each laboratory shall perform chemical analysis in accordance with a QA plan which is compliant with DOE Order 5700.6C (10 CFR 830.120) (DOE 1991), and the Hanford Analytical Services Quality Assurance Requirements Documents (HASQARD) (DOE-RL 1997). In addition, vapor sampling and analysis is conducted in accordance with the Tank 241-Z-361 DQO (Field and Banning 1998), as modified by this SAP.

The SAS tank vapor sampling and analysis program is compliant with the SAS QA Management Plan (Dormant 1998). The WSCF Laboratory analysis program is compliant with the WSCF Laboratory QA Plan (Meznarich 1997) and the 222-S Laboratory analysis program is compliant with the 222-S Laboratory QA Plan (Markel 1998).

Radiochemical analysis of the particulate air filter samples at either the WSCF Laboratory or the 222-S Laboratory will be performed in accordance with Letters of Instruction (LOI) currently in force at each laboratory (Mahon 1996a, 1996b). 


\subsubsection{Data Reporting}

Results of the sample team observations and laboratory analytical results will be reported in one or two potential types of reports. These report formats are standardized and are known as "Format I" and "Format VI" reports.

2.6.4.1 Immediate Notification (Format I). An immediate notification report (Format I) is used to communicate that specific analytes have exceeded an agreed-to threshold specified as "Notification Limit" in Table 2-2. These thresholds relate to potential safety or notification levels leading to some decision or action. Potential actions may include tank access control upgrades or environmental condition notification to the U.S. Department of Energy, Richland Operations Office (DOE-RL). The Format I report includes immediate verbal notification to the Tank 241-Z-361 Project Manager followed within three working days by written communication to the PFP Safety Manager and the Tank 241-Z-361 Project Manager. It is the responsibility of the Tank 241-Z-361 Project Manager to provide immediate verbal notification to the PFP Safety Manager and the EPA Project Manager. The PFP Safety Manager must notify appropriate personnel of significant health and safety issues.

2.6.4.2 Analytical Results (Format VI). Special analytical support and the SAS shall deliver three data reports. Preliminary sampling and analytical data are requested within 3 weeks after receipt of both the samples and supporting data and shall consist of, at a minimum, data tables reporting sample collection data, industrial hygiene tank monitoring data, and radiation screening results of each analysis performed by the analytical laboratories. A draft data package shall be submitted for review within four weeks after receipt of both the samples and supporting data. Comments shall be provided to SAS within one week of receipt of the draft data package and a final data package shall be issued within two weeks of receipt of comments. The final data package is considered a Format VI report and contains the elements listed in Table 2-3, as agreed to by TWRS Characterization and SAS.

The preliminary data report and draft data package shall be submitted to the Z-361 Project Manager by the Tank 241-Z-361 Characterization Manager. The Tank 241-Z-361 Characterization Manager will issue the tank characterization report. The EPA will be on distribution for the report. The Tank 241-Z-361 Project Manager will officially submit the report to Fluor Daniel Hanford and the Fluor Daniel Hanford Program Manager will officially transmit the report to the DOE-RL Transition Program Division Director. DOE-RL will officially transmit the report to the EPA Region 10 office in Richland, Washington. In addition to this data package, an electronic version of the analytical results shall be provided to the Tank Characterization Database representative on the same day that the final data package is issued. 


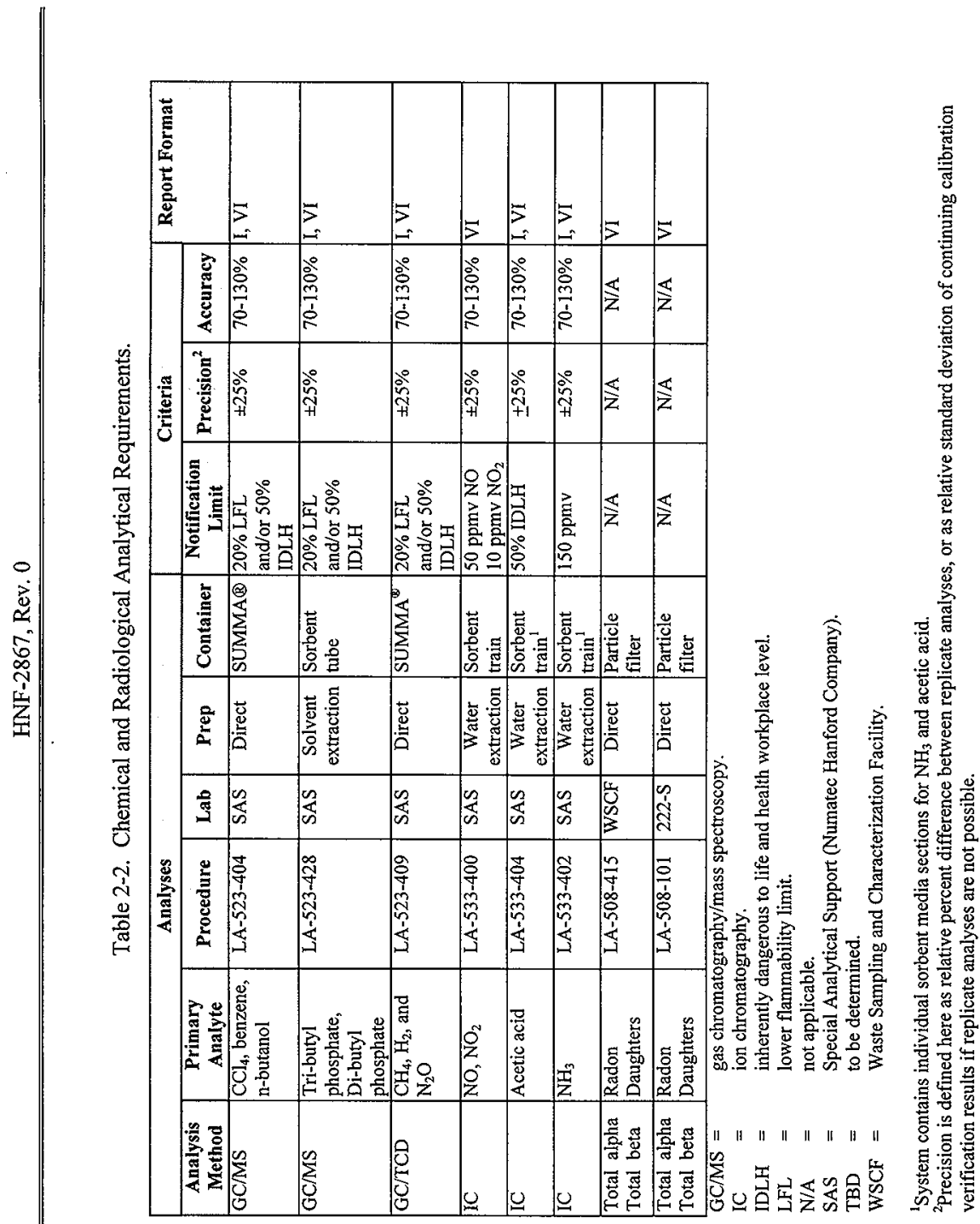


Table 2-3. Final Vapor Report Contents

(Format VI).

\begin{tabular}{|l|}
\hline \multicolumn{1}{|c|}{ Sampling Elements } \\
\hline sampling case narrative \\
\hline sample summary and event chronology \\
\hline sampling procedures table \\
\hline sampling logbook table \\
\hline field-generated vapor total organic carbon (TOC) results \\
\hline industrial hygiene screening data \\
\hline sample radiation screening results \\
\hline chain-of-custody forms \\
\hline \\
\hline analytical case narrative \\
\hline analytical procedures identification table \\
\hline data qualifier flag translation table \\
\hline target analyte and duplicates concentration table \\
\hline tentatively identified compound concentration table \\
\hline laboratory blank summary \\
\hline field blank summary \\
\hline mass spectrometer instrument tune report \\
\hline target analyte initial calibration table \\
\hline target analyte continuing calibration table \\
\hline internal standards area counts table \\
\hline laboratory control sample results table \\
\hline quantitation reports \\
\hline chromatograms \\
\hline mass spectra of reported tentatively identified compounds \\
\hline \\
\hline quality assurance data package review results \\
\hline
\end{tabular}

\subsection{TANK INTERIOR VIDEOGRAPHY}

Since this is a tank-invasive activity, the tank vapor space will be monitored using the sampling port on the breather filter assembly. Tank videography can proceed when the tank atmosphere is lower than $25 \%$ of the LFL as measured by the CGM. The tank will be allowed to passively vent until this is achieved. If field observations indicate that this is unlikely, temporary active ventilation (argon purge) may be performed. Argon gas will be introduced via the sample port line and displaced vapor will exit through the breather filter.

Once the tank atmosphere has been confirmed at less than $25 \%$ of the LFL, an 8 -in. riser will be opened. A specially designed video camera will be lowered into the riser within a sealed sleeve through the breather filer. Depending upon the actual riser condition and tank lighting needs determined in the field, lighting equipment may be lowered down the same 8-in. riser, or through a second riser. This second riser may be the riser with the breather filter or another riser, 
depending on suitability determined in the field. Details of the air emission controls to be used during this task are included in Appendix A.

\subsection{WORK AREA CLEANUP}

The glovebag containment surrounding the initial $7.62 \mathrm{~cm}(3 \mathrm{in}$.) riser will be removed. This may occur at any time after the breather filter assembly has been installed. Sampling and videotaping can occur with the glovebag in place or removed. Before removal, the glovebag interior will be surveyed. If radiological contamination is detected, it will be fixed and the greenhouse containment will be constructed around the riser. The glovebag will then be cut away from the riser within the containment of the greenhouse. If no internal contamination is detected, the glovebag will be removed without the need for greenhouse containment.

All risers will be closed and surveyed. Residual radiological contamination will be mitigated. All waste generated by the tank activities will be bagged and dispositioned, and the safety posting/placarding will be returned to an appropriate status.

\subsection{WASTE MANAGEMENT}

All waste management activities will be performed in accordance with waste management ARARs. These include the substantive waste characterization, designation, handling, and disposal requirements of the Resource Conservation and Recovery Act of 1976 (RCRA) and Washington Administrative Code (WAC) 173-303.

Phase I activities will not directly contact the sludge surface, and therefore will generate only non-transuranic (TRU) waste. Anticipated waste streams may include:

- mixed waste $\left(\leq 1 \mathrm{~m}^{3}\left[1.094 \mathrm{yd}^{3}\right]\right.$ of asbestos-containing material from the riser, contaminated soil, spill cleanup waste, radiologically contaminated dangerous waste, radioactive lead waste);

- low-level waste $\left(\leq 1 \mathrm{~m}^{3}\left[1.094 \mathrm{yd}^{3}\right]\right.$ of low-level waste soil, low-level waste rags and clothing);

- hazardous non-radioactive wastes (rags, batteries, aerosol cans, expired chemical products and containers).

All low-level radioactive and mixed waste streams (with the exception of recyclable materials, equipment, and lead shielding) meeting ERDF waste disposal criteria will be disposed at ERDF. Disposal will meet ERDF acceptance criteria found in Environmental Restoration and Disposal Facility Waste Acceptance Criteria (BHI 1998). While it is unlikely that transuranic waste will be generated, any waste exceeding transuranic ERDF WAC limits will be sent to the Central Waste Complex for disposal. 
Non-radioactive, hazardous waste may be shipped to an offsite disposal facility, provided the waste meets the offsite disposal facility's acceptance criteria. Offsite disposal is also contingent upon the EPA Project Manager's determination of offsite facility acceptability.

\subsubsection{Field-generated Waste}

Field wastes will be segregated, accumulated, bagged, shielded, and labeled according to procedure TO-100-052, "Perform Waste Generation, Segregation, and Accumulation." Recyclable materials will be identified. The procedure describes:

- the establishment and maintenance of Satellite Accumulation Areas for the accumulation of hazardous or dangerous waste;

- the appropriate management of asbestos-containing materials;

- bagging waste;

- recording waste bag contents on Waste Inventory Sheets;

- packaging radioactive wastes and radioactive mixed wastes;

- packaging waste from spills;

- designation;

- documentation.

Field wastes will be accumulated and packaged by the TWRS CPO field team. PFP operations will collect the waste and laundry from the worksite, ensure compliant packaging and transport it to ERDF.

\subsubsection{Samples And Associated Waste}

All laboratory solid wastes are separated, collected, packaged, labeled, and classified in accordance with LO-100-400, "SAS Waste Management." This procedure describes the laboratory's approach to assigning all solid waste streams associated with each analytical procedure to various "waste streams." These "waste streams" are consolidated based on chemical and regulatory compatibility, stored in satellite accumulation areas, and ultimately packaged and designated for appropriate disposal. This project is not anticipated to generate any new or unusual waste streams during the analysis process. 
Figure 2-1. Sample Equipment Configuration Including Breather Filter.

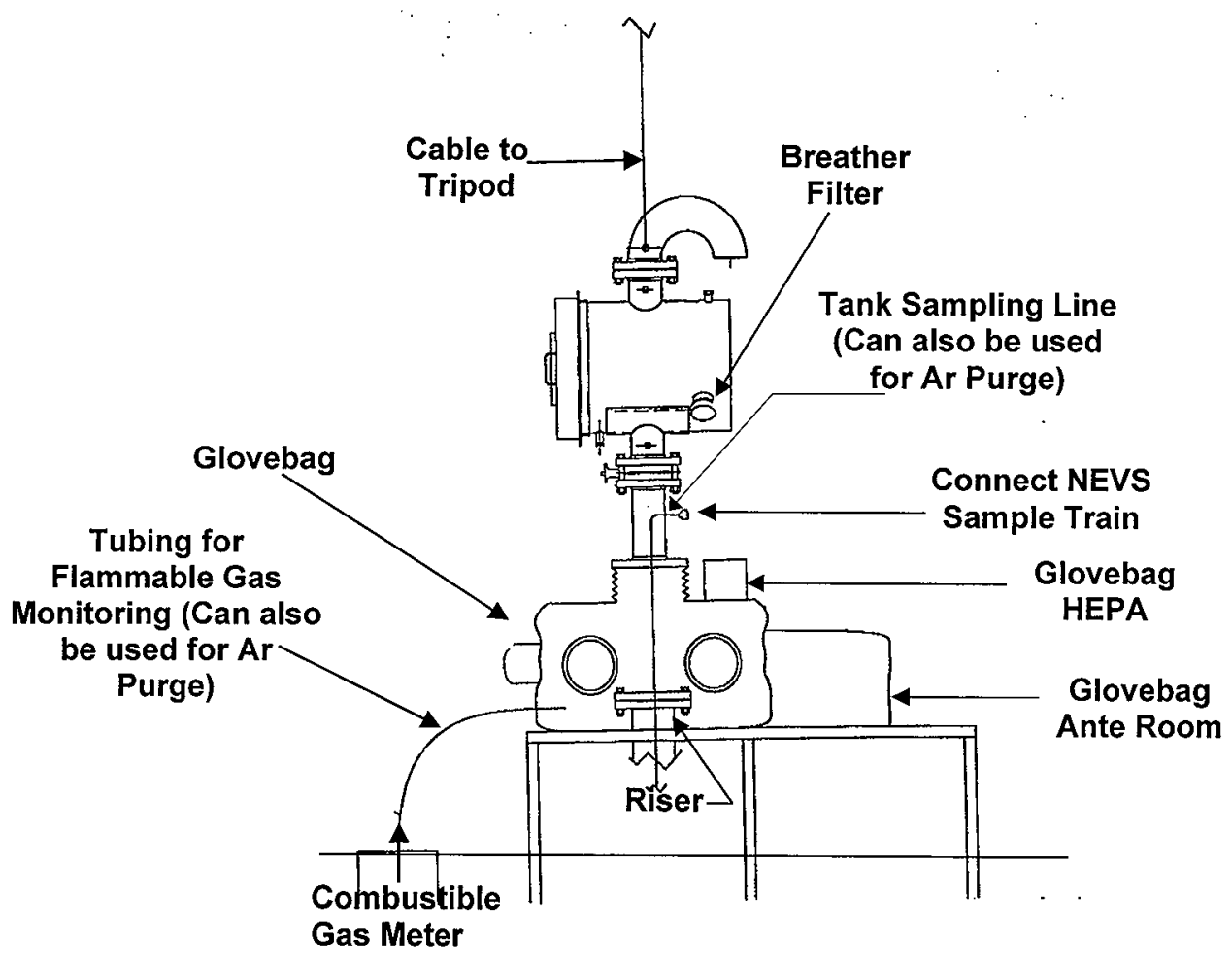




\subsection{QUALITY ASSURANCE PROJECT PLAN}

This Quality Assurance Project Plan (QAPP) presents activities associated with the assurance, demonstration, and measurement of quality of the vapor sample gathering, analysis, and reporting for the Tank 241-Z-361 vapor sampling project. This QAPP follows EPA guidelines contained in the EPA Requirements for Quality Assurance Project Plans for Environmental Data Operations (EPA 1994). This QAPP covers the field activities and resulting environmental data described in Section 2.0.

\subsection{PROJECT MANAGEMENT}

\subsubsection{Project and Task Organization}

The vapor sampling and associated tasks described in this SAP are a subset of the Tank 241-Z-361 Phase I activities described in PHMC (1998) and Bogen (1998).

Tank 241-Z-361 is located within the protected area within the PFP Complex. Therefore, ultimate project responsibility resides with PFP (BW Hanford Corporation [BWHC]). Day-today operations must be authorized by PFP Operations (BWHC). The TWRS CPO (Lockheed Martin Hanford Company) is supplying the personnel to actually perform the tank-intrusive field activities, due to their specialized expertise. TWRS CPO will perform this sampling project and include it into their Tank Vapor Sampling Program administration. Because TWRS has extensive tank vapor sampling experience, TWRS will supply the technical, project management, industrial hygiene, health physics, and engineering technical personnel. A memorandum of understanding is in development between BWHC and LMHC regarding roles and responsibilities, and will be formally signed before work initiation. The vapor sampling and vapor sample analysis will be performed by SAS (Numatec Hanford Corporation [NHC]) under TWRS CPO direction. Radiological analysis of vapor sampling particulate air filters for vapor sample release to the SAS laboratory will be performed by the WSCF Laboratory (Waste Management Federal Services Hanford [WMFSH]). The 222-S Laboratory (WMFSH) will be a back-up of WSCF. All work will be conducted using the safety controls identified in the JCO (PHMC 1998) approved by the DOE-RL and this SAP approved by DOE-RL and EPA.

\subsubsection{Roles and Responsibilities}

This section identifies the roles and responsibilities of the various organizations involved with the Tank 241-Z-361 vapor sampling activities. Table 3-1 shows key project personnel and their areas of responsibility.

The following sections list the duties of each organization performing tasks on the project. 
Table 3-1. Tank Vapor Sampling Project Key Personnel List.

\begin{tabular}{|l|c|c|}
\hline \multicolumn{1}{|c|}{ Individual(s) } & Organization & Responsibility \\
\hline D. M. Bogen & PFP Transition Engineering & Z-361 Project Manager \\
\hline C. Defigh-Price & TWRS Characterization Project & Z-361 Characterization Manager \\
\hline W. Kennedy & TWRS Characterization CPO & Z-361 Field Operations Manager \\
\hline L. L. Reed. & PFP Environment, Safety, & Manager, PFP Safety \\
\hline L. M. Sasaki & TWRS Process Engineering & Vapor Program Technical Lead \\
\hline L. Lockrem & & \\
\hline $\begin{array}{l}\text { L. A. Pingel } \\
\text { NHC Special Analytical Support }\end{array}$ & SAS Laboratory Project Manager \\
\hline R.S. Viswanath & NHC Special Analytical Support & SAS Vapor Sampling Team Lead \\
& & \\
\hline CPO = Characterization Program Operations. & \\
NHC = Numatec Hanford Corporation. & \\
PFP $=$ Plutonium Finishing Plant. \\
SAS = Special Analytical Support. \\
TWRS = Tank Waste Remediation System. \\
\end{tabular}

\subsubsection{PFP Operations/Engineering (BWHC).}

- Manage overall Z-361 program and project

- Implement elements of Z-361 Characterization Plan (Bogen 1998)

- Approve the DQO process report (Field and Banning, 1998)

- Coordinate and obtain Plant Review Committee (PRC) comments and release work through BWHC work control system

- Maintain safety basis and work authorization (e.g., JCO)

- Conduct a contractor standard startup review per HNF-PRO-055

- Release work on a shift-by-shift basis per shift manager's authorization

- Prepare and maintain worksite 
- Provide water, protective clothing, laundry, restroom facilities, waste management services, CAMs, poppies (alpha survey).

\subsubsection{TWRS Characterization Program (LMHC).}

- Implement tasks in the engineering task plan (Bogen 1998).

- Generate DQO, SAP, and health and safety plan.

- Define service requirements (water, electrical, etc.).

- Perform as low as reasonably achievable review.

- Conduct pre-job briefing.

- Conduct mock-up training.

- Assign laydown areas.

- Provide change trailer.

- Design and provide glovebag.

- Manage daily Z-361 characterization operations.

- Initiate work packages.

- Work within the BWHC Project Hanford Management Contract (PHMC) and PFP authorization basis.

- Release samples from the worksite for transportation to the laboratory for analysis.

- Provide shift briefings to PFP Shift Manager.

- Restore site to original condition.

- Evaluate laboratory results and prepare Tank Characterization Report to PFP.

- Input laboratory data into Tank Waste Information Network System (TWINS) database.

\subsubsection{Numatec Hanford Corporation.}

- Design or define specifications for breather filter(s) sampling equipment, sample holders

- Perform vapor sampling

- Perform chemical analysis of vapor 
- Report final results.

\subsubsection{Waste Sample Characterization Facility (WMFSH).}

- Perform total alpha/beta analysis on particulate filter samples.

\subsubsection{222-S Laboratory.}

- Backup lab for total alpha/beta analysis of filter samples.

\subsubsection{Data Users}

- PFP Transition Engineering

- TWRS Characterization Program

- PFP Environmental, Safety and Health

- Environmental Regulators

- TWRS Nuclear Safety and Licensing

- TWRS Inactive Miscellaneous Underground Storage Tank (IMUST) Program.

\subsection{QUALITY OBJECTIVES AND CRITERIA FOR MEASUREMENT DATA}

A DQO process was conducted in accordance with Guidance for the DQO Process (EPA 1994) as implemented according to Data Quality Objectives for Sampling and Analyses (LMHC 1997). Input to the DQO process was provided by members of PFP (engineering, environmental, and laboratory personnel), TWRS Characterization, and SAS. A summary of the contaminants of concern for the 241-Z-361 Tank Vapor, including the basis for generating data has been presented in Table 1-6. Potential action levels, required EQLs, analytical measurement methods, and precision performance requirements have also been presented in Table 1-7.

Data generated as part of this sampling and analysis project must be credible and withstand technical scrutiny by individuals and organizations interested in Tank 241-Z-361 safety issues, safeguards issues, sludge characterization issues, sludge retrieval issues, air emission control issues, and CERCLA remedial activities.

Sampling and vapor analysis activities are being performed using procedures that have been developed for Hanford tank vapor sampling and analysis. In general, these methods are based on EPA analytical methods, adapted for use at Hanford. For example, the GC/MS method, LA-523404, is based upon Method TO-14 (Winberry et al. 1990). Similarly, the ammonia analysis of the sorbent train scrubber solution, LA-533-402, is based on the SW-846 Method 9056. These procedures have been in use and have generated vapor data of known quality for a number of years.

The QA objective of this plan is to develop implementation guidance that will provide data of known and appropriate quality. Data quality is assessed by representativeness, comparability, 
accuracy, precision, and completeness. Definitions of these parameters, applicable guidelines, and level of effort are described below. The applicable QC guidelines, quantitative target limits, and levels of effort for assessing data quality are dictated by the intended use of the data and the nature of the analytical method. The fixed laboratory parameters are presented in Tables 1-7 and 2-2. The nomenclature used to describe quality parameters is contained in the following discussion.

Representativeness is a measure of how closely the results reflect the actual concentration of distribution of the chemical and radiological constituents in the matrix sampled. Sampling plan design, sampling techniques, and sample handling protocols (e.g., storage, preservation, and transportation) have been developed and are discussed in other sections of this document. The documentation will establish that protocols have been followed and sample identification and integrity ensured. Field, system, trip blanks and field duplicates, duplicate SUMMA ${ }^{\circledR}$ canisters, and replicate sorbent tubes and sorbent trains will be used to assess field and transport contamination and method variation. To assess laboratory contamination, laboratory method blanks will be run with every sample preparation/analysis batch of $\leq 20$ samples.

Comparability expresses the confidence with which one data set can be compared to another. Data comparability will be maintained using standard procedures, consistent methods, and units. Tables 1-7 and 2-2 list applicable fixed laboratory methods for analytes and target EQLs. Actual EQLs will depend on the sample matrix, sample quantity available, and will be reported as defined for the specific samples.

Accuracy is an assessment of the closeness of the measured value to the true value. Accuracy of chemical test results is normally assessed by spiking samples with known standards and establishing the average recovery. A matrix spike is the addition to a sample of known amounts of a standard compound similar to the compounds being measured. Surrogates are deuterated compounds spiked in the matrix. Matrix spikes will be used for sorbent train leachate analysis. Whole-air vapor samples are difficult to spike; therefore, matrix surrogate spikes will not be used for air samples. Accuracy is demonstrated using the introduction of internal standards into the vapor stream as it is injected into the gas chromatograph. The laboratory method includes internal standard recovery tolerances. Validity of calibrations are evaluated by comparing results from measurement of standard to known values and comparing to the method tolerances. Table 2-2 lists the accuracy requirements for fixed laboratory analyses for the project.

Precision is a measure of the data spread when more than one measurement has been taken on the same sample. Precision can be expressed as the relative percent difference for duplicate measurements. Both laboratory and field duplicates are included in the project design enabling estimates of laboratory and sampling precision. Precision requirements for fixed laboratory analyses are listed in Tables 1-7 and 2-2.

Completeness is a measure of the amount of valid data obtained from the analytical measurement process and the complete implementation of defined field procedures. Completeness is set at $90 \%$ for field survey and fixed laboratory analyses. 
The EQL is the lowest concentration of an analyte that can be reliably achieved within specified limits of precision and accuracy during routine laboratory operating conditions. The $E Q L$ is determined by a multiplier times the method detection limit (MDL) (e.g., $10 \times$ MDL) or the lowest non-zero standard on the calibration curve. EQLs are functions of the analytical method utilized to provide the data and the quantity of sample available for analyses. Radionuclide EQLs can be reduced by extending the counting time of a measurement point to improve counting statistics.

\subsubsection{Special Training Requirements/Certification}

The activities described in the Health and Safety Plan (Appendix C) provide workers with the knowledge and skills necessary to safely execute assigned duties. A graded approach is used to ensure that workers receive a level of training commensurate with their responsibilities that complies with applicable DOE orders and government regulations. Specialized employee training includes pre-job briefings, on the job training, emergency preparedness, plan of the day, and facility/work site orientations, including all members of the Building Emergency Response Organization. Tables 3-2 and 3-3 present the training and qualifications applicable for facility work and activities. The Health and Safety Plan in Appendix C describes training requirements.

Before initiation of any activities, BWHC will conduct project-specific facility orientation and emergency preparedness training. In addition, BWHC will also conduct a standard startup review per HNF-PRO-055. This formal review will ensure all work prerequisites have been met and all assigned individuals and organizations are adequately prepared and trained for their assigned tasks. 
Table 3-2. Radiological Entry Requirements (Summary Table).

\begin{tabular}{|c|c|c|}
\hline \multicolumn{3}{|c|}{ Visitor Requirements } \\
\hline $\begin{array}{l}\text { All Areas within the tank sampling area } \\
\text { (behind the fence). }\end{array}$ & No & or entries allowed. \\
\hline \multicolumn{3}{|r|}{ Workers } \\
\hline $\begin{array}{l}\text { All Areas within the tank sampling area } \\
\text { (behind the fence). }\end{array}$ & & $\begin{array}{l}\text { Radworker II } \\
\text { Task-specific training as delineated in the governing work } \\
\text { packages (Training Matrix) and applicable AHA's, and } \\
\text { Appendix C, Section } 3 . \\
\text { Pre-Job Safety and Plan-of-the-Day briefings including } \\
\text { updates on ongoing activities and changing field conditions. }\end{array}$ \\
\hline $\begin{array}{l}\text { Entries into RBA and RA. } \\
\text { Entries into CA, HCA, HRA, or ARA. }\end{array}$ & $24-1$ & $\begin{array}{l}\text { Iazwoper and Rad Worker I Training } \\
\text { Iazwoper and Rad Worker II }\end{array}$ \\
\hline
\end{tabular}

Note: DOE Facility Reps may act as the Escort for all DOE business and tours.

ARA $=$ Airborne Radiation Area.

$\mathrm{CA}=$ Contamination Areas.

DOE = U.S. Department of Energy.

HCA $=$ High Contamination Areas.

HRA $=$ High Radiation Areas.

HGET $=$ Hanford General Employee Training.

$\mathrm{RA}=$ Radiation Areas.

$\mathrm{RBA}=$ radiological buffer area. 
Table 3-3. Entry Hazardous Worker Training and Medical Requirements.

\begin{tabular}{|c|c|c|c|c|c|c|c|c|c|}
\hline Visitor & $\begin{array}{l}40 \\
\mathrm{Hr}\end{array}$ & $\begin{array}{l}24 \\
\mathrm{Hr}\end{array}$ & $\begin{array}{l}\text { 24- } \\
\text { OST }\end{array}$ & $\begin{array}{l}8- \\
\text { OST }\end{array}$ & $\begin{array}{l}\text { Supervisor } \\
\text { Training }\end{array}$ & POD & TLD & Escorted & $\begin{array}{c}\text { Haz } \\
\text { Waste } \\
\text { Medical } \\
\end{array}$ \\
\hline $\begin{array}{l}\text { BWHC and LMHC } \\
\text { Support Personnel } \\
\text { (RBA or RA only) }\end{array}$ & & $\mathrm{x}$ & & $\mathrm{x}$ & & $\mathrm{x}$ & $x$ & & $x$ \\
\hline $\begin{array}{l}\text { BWHC and LMHC } \\
\text { Support Personnel } \\
\text { using respirators }\end{array}$ & $\mathrm{x}$ & & $\mathrm{x}$ & & & $\mathrm{x}$ & $x$ & & $\mathrm{x}$ \\
\hline $\begin{array}{l}\text { Industrial Hygiene Tech } \\
\text { RCT }\end{array}$ & $x$ & & $\mathrm{x}$ & & & $x$ & $\mathrm{x}$ & & $\mathrm{x}$ \\
\hline $\begin{array}{l}\text { Field \& Rad } \\
\text { Supervisors } \\
\text { Field Superintendent } \\
\text { Field Safety Rep } \\
\text { Field Engineer } \\
\end{array}$ & $\bar{x}$ & & $\mathrm{x}$ & & $\mathrm{x}$ & & $x$ & & $\mathrm{x}$ \\
\hline $\begin{array}{l}\text { Task Lead \& Rad } \\
\text { Engineer (RBA or RA } \\
\text { only) }\end{array}$ & & $\bar{X}$ & & $\mathrm{x}$ & & $\mathrm{x}$ & $\mathrm{x}$ & & $\mathrm{x}$ \\
\hline \\
\hline \multicolumn{10}{|c|}{$\begin{array}{l}\text { BWHC }=\text { Babcock and Wilcox Hanford Corporation. } \\
\text { LMHC }=\text { Lockheed Martin Hanford Company. }\end{array}$} \\
\hline \multicolumn{10}{|c|}{$=$ Onsite Training. } \\
\hline \multicolumn{10}{|c|}{$=$ Plan of the Day. } \\
\hline \multicolumn{10}{|c|}{$=$ radiological area } \\
\hline \multicolumn{10}{|c|}{$=$ radiological buffer area. } \\
\hline \multicolumn{10}{|c|}{$=$ radiological control technician. } \\
\hline \multicolumn{10}{|c|}{$=$ Thermoluminescent Detector. } \\
\hline
\end{tabular}

\subsubsection{Training Documentation and Records}

Each employee's training records are maintained and continuously updated by the PHMC. Current training status for any PHMC employee is accessible via computer database. More detailed information on this database is included the Health and Safety Plan in Appendix C.

\subsection{MEASUREMENT/DATA ACQUISITION}

The following sections present the requirements for sampling methods, sample handling and custody, analytical methods, field QC, and laboratory QC activities and requirements. Some of this information is presented in Section 2.0, Field Activities, and will be referenced as appropriate.

\subsubsection{Sampling Methods and Requirements}

Vapor Sampling will be performed in accordance with SAS Procedure LO-080-400. This method describes collection of SUMMA ${ }^{\circledR}$ canisters, sorbent tube, and sorbent train samples, and particulate air filter samples. Analytical method references have been previously presented in 
Table 2-2. These analytical methods have been developed exclusively for the Hanford Tank Vapor Program. All sampling and analytical work will conform to HASQARD (DOE 1997), and the SAS Management Plan (Dormant 1998).

Sampling and analysis will conform specifically to the draft Quality Assurance Project Plan for Tank Vapor Characterization (Keller 1994) and Board (1998).

\subsubsection{Sample Management}

3.3.2.1 Custody. The laboratory supplying the sample collection media shall initiate the chainof-custody documentation. Once the sample containers and collection media have been received by the SAS sampling team from the laboratory, they will remain under the "physical control" of the [SAS laboratory] sample custodian, locked in a secure area, or prepared for shipping with tamper-evident tape. "Physical control" means that the sample is either in-sight of the custodian, in a room which shall signal an alarm when entered, or in a locked cabinet or storage area. Chain-of-custody documentation will follow the canisters, sorbent trains, and air filters in accordance with procedure LO-090-450, "Sample Chain-of-Custody, Acceptance, and Disposal" and LAP-94-400, "Laboratory and Sample Security."

In general, all sample handling, transportation and custody requirements will be performed in accordance with applicable sections of:

- Quality Assurance Management Plan Special Analytical Support (Dormant 1998).

- Quality Assurance Project Plan for Sampling and Analysis of Waste Tank Headspace Vapors (Keller 1994).

3.3.2.2 Preservation. Sample container and preservation requirements are described in the vapor sampling procedure (LO-080-400). SUMMA ${ }^{\circledR}$ canister, sorbent tube and sorbent train sample container preparation is described in the sample preparation procedure (LO-080-406 [SUMMA ${ }^{\circledR}$ ] and LA-549-402 [sorbent trains]). All samples will be transported by the SAS vapor sampling team to the 600 area and placed into refrigerated $\left(<4^{\circ} \mathrm{C}\right)$ storage until the samples are released for laboratory analysis.

3.3.2.3 Holding times. Samples will be held for a maximum of 30 days.

3.3.2.4 Shipping. Sample collection media will be transported from the generating laboratory, to the sampling team and into the field in accordance with the chain-of-custody requirements in LO-090-450, "Sample Chain-of-Custody, Acceptance, and Disposal." After the media is used, they will be released from the tank worksite by TWRS Characterization Project Radiological Control HPT in accordance with HNF-IP-0718 by swipes and direct survey to assess removable and total radioactivity. Samples will then be transported by truck or van to the SAS sample storage area in the 600 Area Weather Station Complex. Particulate air filters will be further transported to WSCF. 


\subsubsection{Analytical Method Requirements}

Vapor Sample analytical laboratory procedures and performance requirements for precision (\%RPD) and accuracy (\% recovery) are presented in Section 2.6, Table 2-2. Method details for the tri-butyl phosphate/di-butyl phosphate and acetic acid analyses will be in-place before analysis and will be validated per HASQARD Sections 5.6 and 5.7.

\subsubsection{Radiological Surveys}

Alpha and beta/gamma surveys will be used in the field during the activities at-tank. TWRS Characterization Program Radiological Control HPTs will perform the surveys for releasing samples, tools, re-usable items and waste from the worksite. Material release and instrument operation will comply with HNF-IP-0718, Section 6.1, "Release Surveys for Materials and Equipment."

\subsubsection{Industrial Hygiene Surveys}

Tank vapor will be continuously monitored by TWRS Industrial Hygiene personnel using a CGM. Percent LFL will be monitored and will be used to make field decisions regarding inert gas purging of the glovebag surrounding the tank riser, passive or active venting of the tank riser volume before invasive activities such as videotaping, and continuous monitoring during the sampling and photographing process. The CGM will be operated according to manufacturer's direction. In addition, Draeger tubes will be used to monitor for carbon tetrachloride in workplace air. The Draeger tubes will be exposed and read according to manufacturer's directions. Results will be recorded in a logbook and preserved in the project file. Field CGM and Draeger-tube results will be reported in the final SAS report.

\subsubsection{Quality Control Requirements}

This characterization effort relies on both field measurements and laboratory sample analysis. QA is built into each phase of characterization in the form of field instrument operational checks and laboratory analytical procedure controls.

3.3.6.1 Field Instrument Checks. The alpha and beta/gamma survey instruments are calibrated annually using known standards by a certified laboratory. Daily calibration checks are performed by the TWRS Characterization Project Radiological Control Organization on each instrument released to the field. Periodic response checks are performed against sources integral to the instruments during the course of the day. 


\subsubsection{Laboratory Quality Control Samples.}

- Field, system, and trip blanks will be collected to assess the cleanliness of the sampling equipment, the effectiveness of the sample decontamination process, and potential sampling environment contaminant contribution. Equipment blanks will be collected in the field by pulling ambient air through the NEVS sample lines into a clean SUMMA ${ }^{\circledR}$ canister. The blank will be analyzed for the same chemical analytes as actual tank vapor samples collected during use of the equipment. A system blank will be collected by sampling ambient air through the entire length of the NEVS sample line. A trip blank will travel with the sorbent tubes from the laboratory, to the sample site, and back to the laboratory. All sample results should be evaluated to determine the possible effects of any contamination that may be detected in the equipment blank.

- Field duplicates are two samples of the same matrix being sampled. Field duplicates will be taken with both SUMMA ${ }^{\circledR}$ canisters, sorbent tubes, and sorbent trains as shown in Table 2-1. Field duplicates are analyzed independently and provide information concerning the homogeneity of the matrix, as well as an evaluation of the precision of the sampling and analysis process.

Control measures taken to monitor laboratory performance include:

- One laboratory method blank for every 20 samples (5\% of samples), analytical batch or sample delivery group (whichever is most frequent) will be carried through the complete sample preparation and analytical procedure. The method blank will be used to document contamination resulting from the analytical process.

- One laboratory control sample or blank spike will be performed for every batch of samples for each analytical method criteria to monitor the effectiveness of the sample preparation process. The results from the analyses are used to assess laboratory performance.

- A matrix spike sample will be prepared and analyzed for every 20 samples (as applicable to method) of the same matrix or sample preparation batch, whichever is most frequent. The matrix spike results are used to document the bias of an analytical process in a given matrix.

- Matrix spikes and matrix spike duplicates are used in the sorbent train leachate analytical method. However, the whole-air sample analyses do not include matrix spikes. Instead, internal standards are injected with the gas sample into the analytical instrumentation. Evaluation of the internal standard recoveries provide similar information for accuracy assessment.

- Laboratory duplicates or matrix spike duplicates will be used to assess precision and will be analyzed at the same frequency as the matrix spikes. 


\subsubsection{Instrument/Equipment Testing Inspection, and Maintenance Requirements}

Measurement and testing equipment used in the field or in the laboratory that directly affects the quality of analytical data will be subject to preventative maintenance measures that ensure minimization of measurement system downtime. Laboratories and onsite measurement organizations must maintain their equipment. Maintenance requirements, such as parts lists and instructions, and documentation of routine maintenance, will be included in the individual laboratory and onsite measurements organization QA plan or operating procedures.

\subsubsection{Instrument Calibration Frequency}

Operations procedures for all field and analytical laboratory equipment specify calibration requirements and frequency. Analytical procedures provide for initial and continuing calibration verification during the sample analysis process with criteria that would indicated the need for recalibration. Field radiological equipment have calibration expiration dates on the instrument.

\subsection{DATA QUALITY ASSESSMENT}

SAS manages an ongoing program for quality assessment, documentation, and corrective action. This program includes external and internal audits, performance evaluation programs, QA letters of observation and other elements. The ongoing status of these activities is summarized in a monthly report described in LQ-529-400, "Quality Assurance Reports to Management: Vapor Report."

In addition, TWRS Data Assessment and Interpretation organization will review the SAS data report to assure that the report meets the requirements of the $\mathrm{SAP}$ and $\mathrm{DQO}$, as applicable. Before a final tank characterization report is issued, a letter report from TWRS Data Assessment will be provided to DOE and EPA. This group will produce a report which provides interpretation of the data, along with information from historical records and previous sampling events. This interpretive report will include the letter report and will be written after sludge/sampling data from Phase II have been generated. 


\subsection{REFERENCES}

10 CFR 830, "Nuclear Safety Management," Section 120, Quality Assurance Requirements, Code of Federal Regulations, as amended.

BHI, 1998, Environmental Restoration and Disposal Facility Waste Acceptance Criteria, BHI00139, Bechtel Hanford, Inc., Richland, Washington.

Board, D.C., 1998, Tank Waste Remediation System Characterization Project Quality Policies, HNF-SD-WM-QAPP-025, Rev. 4, Lockheed Martin Hanford Corporation, Richland, Washington.

Bogen, D.M., 1997, 241-Z-361 Characterization Program Plan, HNF-1532, Rev. 0, Babcock and Wilcox Hanford Corporation for Fluor Daniel Hanford, Inc., Richland, Washington.

Clean Air Act, 42 U.S.C. 7401 , et seq.

Comprehensive Environmental Response, Compensation, and Liability Act of 1980, 42 U.S.C. 9601 et seq.

Dodd, D.A., 1976, Results of 361-Z Sludge Characterization (letter to D.C. Lini, November 22), Atlantic Richfield Hanford Company, Richland, Washington.

DOE, 1991, Quality Assurance, DOE Order 5700.6C, U.S. Department of Energy, Washington, D.C.

DOE-RL, 1992, Z-Plant Source Aggregate Area Management Study Report, DOE/RL-91-58, Rev. 0, U.S Department of Energy, Richland Operations Office, Richland, Washington.

DOE-RL, 1997, Waste Site Grouping for 200 Areas Soil Investigations, DOE/RL-96-81, Rev. 0, U.S. Department of Energy, Richland Operations Office, Richland, Washington.

DOE-RL, 1997, Hanford Analytical Services Quality Assurance Requirements Document, DOE/RL-96-68, Rev. 1, U.S. Department of Energy, Richland Operations Office, Richland, Washington.

Dormant, C., 1998, Quality Assurance Management Plan Special Analytical Support, HNF-SDWM-QAPP-034, Rev. 2, Numatec Hanford Corporation for Fluor Daniel Hanford, Inc., Richland, Washington.

Ecology, EPA, and DOE, 1994, Hanford Federal Facility Agreement and Consent Order, 2 vols., as amended, Washington State Department of Ecology, U.S. Environmental Protection Agency, and U.S. Department of Energy, Olympia, Washington. 
EPA, 1994, Guidance for the Data Quality Objectives Process, EPA QA/G-4, U.S.

Environmental Protection Agency, Washington, D.C.

EPA, 1996, Test Methods for Evaluation Solid Waste Physical/Chemical Methods, SW-846, 3rd Edition, as amended by Updates I (July, 1992), IIA (August, 1993), IIB (January, 1995), and III, U.S. Environmental Protection Agency, Washington, D.C.

FDNW, 1997, Hazard Analysis of Tank Z-361, HNF-SD-CP-CN-003, Fluor Daniel Northwest, Richland, Washington.

Field, J.G. and D.L. Banning, 1998, Tank 241-Z-361 Waste Characterization Data Quality Objective: Headspace Vapor and Tank Structure, HNF-2176, Rev. 0, Lockheed Martin Hanford Corporation, Richland, Washington.

Freeman-Pollard, J.R., 1994, Engineering Study of 50 Miscellaneous Inactive Underground Radioactive Waste Tanks Located at the Hanford Site, Washington, WHC-SD-EN-ES040, Westinghouse Hanford Company, Richland, Washington.

Jones, S.A., 1997, Tank 241-Z-361 Process and Characterization History, HNF-1989, Rev. 0, Babcock and Wilcox Hanford Corp. for Fluor Daniel Hanford, Inc., Richland, Washington.

Keller. K.K., 1994, Quality Assurance Project Plan for Sampling and Analysis of Waste Tank Headspace Vapors, WHC-SD-WM-QAPP-013, Rev. 2, Lockheed Martin Hanford Corporation for Fluor Daniel Hanford, Inc., Richland, Washington.

Lipke, E.J., C.A. Rogers, and E.M. Miller, 1997, Engineering Study of the Criticality Issues Associated with Hanford Tank 241-Z-361, HNF-2012, Rev. 0, Duke Engineering \& Services Hanford for Fluor Daniel Hanford, Inc., Richland, Washington.

LMHC, 1997, Data Quality Objectives for Sampling and Analyses, HNF-EP-0845, IV, "Engineering," Lockheed Martin Hanford Corporation for Fluor Daniel Hanford, Inc., Richland, Washington.

Mahon, R.D., 1996a, Letter of Instruction (LOI-SASWV-96-002) and Work Order E29937 for SAS Filter Samples to 222-S Analytical Laboratory (Internal memorandum 75770-96-011 to D.B. Hardy, February 26), Numatec Hanford Corporation for Fluor Daniel Hanford, Inc., Richland, Washington.

Mahon, R.D., 1996b, Letter of Instruction (LOI-SASWV-96-003) and Work Order E46353 for SAS Filter Samples to WSCF Analytical Laboratory (Internal memorandum SAS-7574596-061 to A.K. Dasgupta, September 12), Numatec Hanford Corporation for Fluor Daniel Hanford, Inc., Richland, Washington.

Markel, L.P., 1998, 222S Lab QA Plan, HNF-SD-CP-QAPP-016, Waste Management Federal Services of Hanford, Inc. for Fluor Daniel Hanford, Inc., Richland, Washington. 
Meznarich, H.K., 1997, Waste Sampling and Characterization Facility Laboratory Quality Assurance Plan, HNF-SD-CP-QAPP-017, Rev. 2, Waste Management Federal Services of Hanford, Inc., for Fluor Daniel Hanford, Inc., Richland, Washington.

National Environmental Policy Act of 1969, 42 U.S.C. 4321, et seq.

PHMC, 1997, Nonconforming Item Reporting and Control, HNF-PRO-298, Rev. 0, Fluor Daniel Hanford, Inc., Richland, Washington.

PHMC, 1998, Justification for Continued Operation for Tank 241-Z-361, HNF-2024, Rev. 0A, Prepared by the PHMC Companies and The Chiron Group LLC, Richland, Washington.

Resource Conservation and Recovery Act of 1976, 42 U.S.C. 6901 et seq.

Wagoner, J.D., 1997, Contract No. DE-AC06-96RL13200 - Unreviewed Safety Question (USQ) Regarding Plutonium Finishing Plant (PFP) Tank 241-Z-361 (letter, 97-TPD-193, October 15), U.S. Department of Energy, Richland Operations Office, Richland, Washington.

WAC 173-303, "Dangerous Waste Regulations," Washington Administrative Code, as amended.

WAC 173-460, "Controls for New Source of Toxic Air Pollutants," Washington Administrative Code, as amended.

Winberry, W.T. Jr., N.T. Murphy, and R.M. Riggan, 1990, Methods for the Determination of Toxic Organic Compounds in Air, EPA Methods, Noyes Data Corporation, New Jersey. 


\begin{abstract}
APPENDIX A
RADIOACTIVE AIR MONITORING PLAN FOR CONTROLLING AND MONITORING EMISSIONS FROM VENTING, SAMPLING AND PURGING UNDERGROUND STORAGE TANK 241-Z-361
\end{abstract}




\section{TABLE OF CONTENTS}

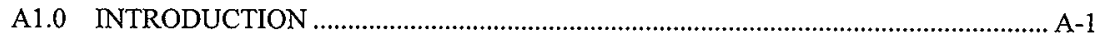

A2.0 FACILITY LOCATION (Requirement 1) ……...................................................... A-1

A3.0 RESPONSIBLE MANAGER (Requirement 2)....................................................... A-2

A4.0 TYPE OF PROPOSED ACTION (Requirement 3) ….............................................. A-2

A5.0 STATE ENVIRONMENTAL POLICY ACT (SEPA) (Requirement 4) ....................... A-2

A6.0 PROCESS DESCRIPTION (Requirements 5 and 7) .............................................. A-2

A7.0 ANNUAL POSSESSION QUANTITY AND PHYSICAL FORM (Requirements 10, 11, and 12) ............................................................................ A-4

A8.0 CONTROL SYSTEM (Requirement 6) ................................................................ A-5

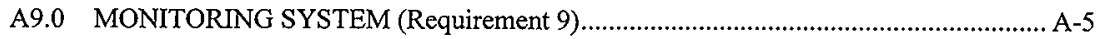

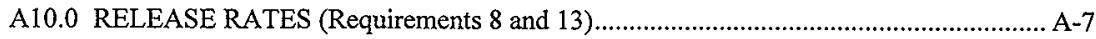

A11.0 OFFSITE IMPACT (Requirements 14 and 15) ……...............................................

A12.0 COST FACTORS AND FACILITY LIFETIME (Requirements 16 and 17)................ A-8

A13.0 TECHNOLOGY STANDARDS (Requirement 18) ..................................................

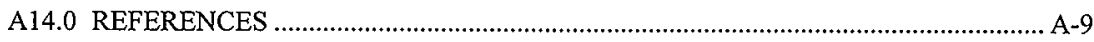

\section{FIGURES}

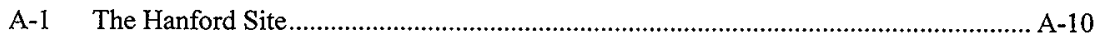

A-2 Typical Video Camera and Sleeving ……............................................................. A-1

A-3 Sample Equipment Configuration Including Breather Filter ....................................... A-12

A-4 Flow Diagram-Containment Structure Over Open Riser ........................................ A-13

A-5 Near Field Surface Monitor Locations Near UST 241-Z-361 …………...................... A-14 


\section{TABLES}

A-1 Estimated Annual Possession Quantity ................................................................ A-5

A-2 Estimated Annual Release .............................................................................. A-7

A-3 Estimated Annual Offsite Dose ......................................................................... A -7

A-4 Emissions Control Equipment Standards Compliance ............................................... A-8

\section{ATTACHMENTS}

A-1 ESTIMATED ANNUAL POSSESSION QUANTITY UNDERGROUND STORAGE TANK 241-Z-361.

A-2 ALTERNATIVE METHOD FOR CONTINUOUS MEASUREMENT OF EMISSIONS UNDERGROUND STORAGE TANK 241-Z-361 Att-A2-1

A-3 DISCUSSION OF BEST AVAILABLE RADIONUCLIDE CONTROL TECHNOLOGY (Requirement 16). 


\section{A1.0 INTRODUCTION}

This radioactive air monitoring plan establishes the method of controlling and monitoring radioactive air emissions for the venting, purging and sampling of inactive Tank 241-Z-361. The plan addresses the substantive requirements of Washington Administrative Code 246-247 and 40 Code of Federal Regulations Part 61 Subpart $\mathrm{H}$.

The activities covered under this plan, not necessarily in the order given, include:

- Open tank risers (minimum of one)

- Install breather (HEPA) filters on one to two risers that remain vented to the atmosphere

- Purge riser/tank, if required, with an inert gas (e.g., argon, carbon dioxide or other suitable gas) to eliminate the possibility of a hydrogen explosion if near or greater than $25 \%$ of the lower flammability limit (LFL) for hydrogen (LFLH $2=4 \%$ by volume)

- Obtain tank vapor samples

- Video tape the inside of tank

- Move a maximum of one (1) cubic yard of soil, if required, around Tank 241-Z-361 for inspection of tank sidewalls, leveling of equipment, or placement of signs.

\section{A2.0 FACILITY LOCATION (Requirement 1)}

Tank 241-Z-361 is located outside towards the southeast corner of the Z-Plant security fence and within the 200 West Area of the Hanford Site (Figure A-1). The latitude and longitude is as follows:

- Latitude: 46 degrees 32 minutes 57.3 seconds

- Longitude: 119 degrees 37 minutes and 55.9 seconds.

The site address is as follows:

U.S. Department of Energy, Richland Operations Office

825 Jadwin Avenue

P. O. Box 550

Richland, Washington 99352. 


\section{A3.0 RESPONSIBLE MANAGER (Requirement 2)}

The responsible manager's name and address are as follows:

Mr. L. D. Romine, Director

Transition Program Division

U.S. Department of Energy, Richland Operations Office

P.O. Box 550 MSIN R3-79

Richland, Washington 99352

(509) $376-4747$.

\section{A4.0 TYPE OF PROPOSED ACTION (Requirement 3)}

The proposed action will create a new emission unit. The proposed action entails internal inspection, sampling and venting Tank 241-Z-361 to atmosphere. Tank 241-Z-361 has been closed to the atmosphere since 1985. The actions to complete this task include installation of breather (HEPA) filters, sampling the vapor space, videotaping the inside of the tank, excavation of soil for possible external inspection of tank sidewalls, and if necessary, purging the tank riser and associated glovebag with an inert gas (e.g., argon, carbon dioxide or other suitable gas) to eliminate the possibility of a hydrogen explosion.

Pursuant to WAC 246-247-030(16) and (25), this action constitutes a significant modification.

\section{A5.0 STATE ENVIRONMENTAL POLICY ACT (SEPA) (Requirement 4)}

National Environmental Policy Act (NEPA)/SEPA is incorporated as an applicable or relevant and appropriate requirement (ARAR) under CERCLA.

\section{A6.0 PROCESS DESCRIPTION (Requirements 5 and 7)}

Between 1949 and 1973, Tank 241-Z-361 was used as a settling tank prior to discharging liquid effluent streams to the soil column. Tank 241-Z-361 received waste from the Plutonium Reclamation Facility (236-Z Building), Plutonium finishing Plant (234-5Z Building) and the Incinerator Building (232-Z). The waste streams consisted of plutonium contaminated spent aqueous solutions, spent organic wastes, and non-contact cooling water. Lines into and out of Tank 241-Z-361 were blanked off in 1975 and the supernate pumped from the tank in the 1975 1977 timeframe. All risers were sealed with blind flanges in 1985. 
Tank $241-Z-361$ has a nominal volume of 45,000 gallons (currently containing approximately 20,000 gallons of liquid/sludge) consisting of a steel lined rectangular concrete tank. The dimensions of Tank 241-Z-361 are 26 feet in length, 13 feet in width and a depth that slopes from 17 to 18 feet. The tank has an estimated liquid/sludge layer approximately 8 feet deep (WHC 1990).

Because of the previous isolation activities on Tank 241-Z-361, the tank has not been directly vented to atmosphere for the past 13 years. There is a possibility that the integrity of the tank has deteriorated; therefore, the tank may be venting to the soil column or atmosphere. Since the integrity of the tank is unknown, it has been assumed that the tank is pressurized due to the presence of hydrogen gas from radiolytic breakdown of water and remaining organic compounds. In the event that the tank is pressurized, the expected internal pressure is expected to be as high as 16 pounds per square inch ( 0.11 megapascals). The maximum pressure is based on the assumption that no hydrogen gas has escaped from the tank (HNF 1998).

To further reduce risk prior to opening the first riser, the riser bolts will be replaced with new bolts made of a non-sparking material. Furthermore, a non-sparking insert will be placed between the riser and the flange before it is lifted off. Because of the potential tank pressurization, there is a potential for worker injury from the flange and uncontrolled spread of radionuclides to the environment if the flange was removed improperly. To mitigate these concerns, the following steps will be performed.

Using HEPA filtered glovebag, one tank riser will be opened for relief of initial tank pressure as described in Section 2.3 of the SAP. The breather filter assembly will be supported above the riser and sealed to the top sleeve of the glovebag before tank pressure is released. The bottom sleeve of the glovebag will be tapped to the riser.

The release rate from the tank will be controlled to protect the glovebag and HEPA filter(s) attached to the glovebag. All tools used to install equipment to the tank riser will be nonsparking. The approach involves the use of a circumferential flow-restricting band with an orifice of $1 / 8$ in. $(0.32 \mathrm{~cm})$ to limit the flow rate. The flow rate can be further throttled or increased by adjusting the torque on the riser flange bolts. This can control the tank relief flow rate to an acceptable value of six (6) standard cubic feet $\left(0.168 \mathrm{~m}^{3}\right)$ per minute or less for maintaining the integrity of a typical constructed glovebag. Once the tank has completely vented to atmospheric pressure and a relief path has been verified, a non-sparking insert will be slid between the riser and the flange to prevent inadvertent contact between them. The flange will then be lifted off the riser. If needed, an inert purge will be applied to the tank riser volume via a hose to keep the glovebag containment and riser volume less than $25 \%$ of the LFL. Confirmatory testing of the glovebag at six (6) standard cubic feet $\left(0.168 \mathrm{~m}^{3}\right)$ per minute will be performed to ensure that the integrity of the glovebag and HEPA filter(s) attached to the glovebag are maintained.

In the event that the tank vapor space hydrogen concentration is close to or greater than $25 \%$ of the LFL for hydrogen, or will not passively ventilate to less than $25 \%$ of the LFL, the tank riser and/or tank will be purged by an inert gas (e.g., argon, carbon dioxide or other suitable gas) to displace the hydrogen in the tank riser to a concentration low enough to alleviate the concern of a hydrogen explosion. 
Once the tank is vented and the LFL in the riser and glovebag are $<25 \%$, samples of the tank vapor will begin. The vapor space contents of the tank will be sampled by installing a breather filter and attaching the sampling equipment to the fitting located on the side of the breathing filter apparatus. Tank sampling will be performed to determine if the hydrogen concentration is close to or exceeds $25 \%$ of the LFL and to determine other chemical constituents that are in the vapor space. Samples will be collected in SUMMA ${ }^{B}$ canisters, sorbent trains and particulate filters.

After sampling, if necessary, purging of the tank will occur via the sample port line that is vented through the breather filter with the HEPA filter attached before opening the second riser for video work. Videotaping will be within a sealed sleeve via a second riser. The breather filter will be in place on the first riser throughout the videotaping.

To aid in assessing the integrity of Tank 241-Z-361, the inside of the tank will be videotaped. Videotaping the inside of the tank, as shown in Figure A-2, will be accomplished by opening a riser, removing the blind flange or breathing filter apparatus, and inserting the video camera into the riser and down into the tank vapor space. After videotaping the inside of the tank, the video camera will be removed from the tank, decontaminated, if necessary, and a blind flange or breathing filter apparatus will be installed on the riser.

Further tank integrity assessments of Tank 241-Z-361 may be required. Additional assessments may include the need to move up to approximately one (1) cubic yard of soil from above the tank to level equipment and install barriers and signs, and to visually and/or nondestructively evaluate the integrity of the tank. Removal of the soil will be performed by hand excavation.

\section{A7.0 ANNUAL POSSESSION QUANTITY AND PHYSICAL FORM (Requirements 10, 11, and 12)}

The radionuclides within Tank $241-Z-361$ are assumed to be in the form of particulate solids and are expected to be released as particulates. The plutonium inventory within the tank has been estimated to be between 30 to 70 kilograms (HNF 1997) of weapons grade plutonium ( $6 \%$ $\mathrm{Pu}$-240). The curie content of americium (Am) was assumed to be $25 \%$ of the total plutonium curie inventory based on core samples obtained from the Z-12 Crib which is a former discharge point of Tank 241-Z-361 (HNF 1997). For conservatism, 70 kilograms of Pu-239 was used as the plutonium source term ( $\mathrm{Pu}-239$ has the highest offsite dose consequence for the plutonium isotopes) which resulted in 316 grams of Am-241 as shown in Attachment A-1.

The annual possession quantity from soil excavation was conservatively estimated assuming the soil was contaminated, on average, at the detection levels of the field instruments and assuming that the beta/gamma reading was entirely strontium ( $\mathrm{Sr}-90)$ and the alpha reading was entirely americium (Am-241). Sr-90 has the highest offsite dose consequence for any expected beta/gamma emitters and Am-241 has a higher offsite dose consequence than the plutonium isotopes. Quantities of other alpha emitters (e.g., neptunium and uranium) and beta/gamma 
emitters in general (e.g., iodine and cesium) are expected to be relatively insignificant since they were removed and separated in the plutonium uranium extraction process before the effluent reached Tank 241-Z-361.

The total annual possession quantity is summarized in Table A-1. A detailed breakdown of the annual possession quantity for the activities described in this plan are provided in Attachment A-1.

Table A-1. Estimated Annual Possession Quantity.

\begin{tabular}{|l|l|}
\hline \multicolumn{1}{|c|}{ Isotope } & \multicolumn{1}{c|}{ Curies } \\
\hline $\mathrm{Sr}-90$ & $4.12 \mathrm{E}-03$ \\
\hline $\mathrm{Pu}-239$ & $4.34 \mathrm{E}+03$ \\
\hline $\mathrm{Am}-241$ & $1.09 \mathrm{E}+03$ \\
\hline Total & $5.43 \mathrm{E}+03$ \\
\hline
\end{tabular}

\section{A8.0 CONTROL SYSTEM (Requirement 6)}

The radioactive emissions are expected to be in the form of particulates. As a result, a single stage HEPA filter will be used for the glovebag, containment structure ventilation system, for each riser left open for venting Tank 241-Z-361 to atmosphere. All HEPA filters utilized with the powered ventilation will have a minimum efficiency of $99.95 \%$ for particles with a median diameter of 0.3 microns. All HEPA-type filters utilized for passive ventilation will have been bench tested to assure HEPA rating, and similar efficiencies are expected during passive flow conditions, based on extensive experience with other passive filters on site. Flow diagrams for the breather filter and containment structure are shown in Figures A-3 and A-4. One riser will be opened for vapor sampling. After the LFL monitoring and vapor sampling are safely completed, two risers will be opened for photodocumentation.

\section{A9.0 MONITORING SYSTEM (Requirement 9)}

For worker safety (unnecessary exposure) and to reduce the spread of contamination from Tank 241-Z-361 to the environment, an active ventilation system will not be used for most of the work activities performed under this plan. Most of the work activities described in this plan will be performed within a HEPA filtered glovebag. Not using an active ventilation system will reduce the motive force to move radionuclides from Tank $241-\mathrm{Z}-361$ into the environment. During the removal of the glovebag, if internal radiological contamination of the glovebag is detected a containment structure will be erected which will include a HEPA-filtered exhauster. The exhauster for the containment structure will contain a HEPA filter and record filter in series. If 
no glovebag containment internal contamination is detected, the glovebag will be removed without the need for a containment structure.

To verify the correct operations of the HEPA filter that is connected to the breather filter, a standard DOP test will be performed annually. The small record filters and filters on the glovebag are purchased pre-tested and certified. The glovebag will be tested for leaks after installation on the riser and before the riser is opened.

Since a passive ventilation system will be used for most work performed under this Plan, and if a containment structure is used, any contaminated structure exhauster will operate for a relatively short period of time, the design and operation of a continuous monitoring system is not always practical. In accordance with 40 CFR 61.93(2)(ii) an alternative method will be used. Attachment A-2 contains a detailed description of the proposed alternative monitoring method and how this method is equivalent to or better than a continuous monitoring system. Measurement of the emissions from the breather filters will be performed quarterly for the tank emissions by either destructive or nondestructive analysis of a second in-line filter downstream of the HEPA breather filter(s). The second in-line filter installed on the glovebag(s) and containment structure will be analyzed after the activities identified in this Plan have been completed. The second in-line filter will have a minimum efficiency of 90 percent for particles with a median diameter of 0.3 micrometers.

In the event that soil movement is required, it will be performed using manual hand tools and potential emissions will be limited to minor diffuse or fugitive releases and will be monitored by the near surface field monitors surrounding Tank 241-Z-361.

Soil excavation is limited to $1 \mathrm{yd}^{3}\left(0.914 \mathrm{~m}^{3}\right)$. The small amount of movement of soil is required to allow leveling of equipment. Radiological ground surveys since 1985 have not shown surface contamination. The calculations in this appendix are conservative case. Near field air monitors will be checked to confirm operation before and after any soil excavations.

During excavation activities, the soil will be surveyed by Radiological Control Technicians (RCTs). If "hot specks" are detected, during the radiological surveys, the "specks" will be removed and containerized before the excavation is allowed to continue. The detection of soil reading 10,000 counts per minute $(\mathrm{cpm})$ per probe size $\left(15 \mathrm{~cm}^{2}\right)$ beta-gamma, using a GM/P-11 probe, and $5 \mathrm{cpm}$ per probe size $\left(57 \mathrm{~cm}^{2}\right)$ alpha, using a portable alpha meter (PAM), will be used as the stop work levels during excavation. EPA will be notified if a stop work level is exceeded. The contaminated soil will be segregated from the "clean" soil during excavation, in spoil piles. Contaminated soil in spoil piles will be controlled using either water, fixatives or covers. Backfill will be made with original soil or with fill as determined by the RCT(s). After backfilling, the area will be surveyed to verify that radiological contamination on the soil surface is below standards. If above-standard radiological contamination is present on the surface, the contamination will be removed and containerized for disposal, covered, or fixed. Fugitive emissions associated with hand excavation will be measured using by the near field surface monitors $\mathrm{N}-165, \mathrm{~N}-433$, and N-964 surrounding Tank 241-Z-361. The near field surface monitors surrounding Tank 241-Z-361 are shown in Figure A-5. The near field monitors will be 
checked for operability within one hour before and within one hour after any soil excavation. All other venting and video work has record filters in place to measure any potential emissions.

\section{A10.0 RELEASE RATES (Requirement 8 and 13)}

A release fraction of 5.00E- 05 was used for all the activities described in this Plan. The maximum expected pressure is 15.5 psi. The most likely pressure is 2 to 3 psi. The release fraction is based on a low pressure release $(<0.35$ megapascals or $<50$ psi) associated with the depressurization of containment via a venting or a failure above the liquid level (Page 3.3 of Volume I, DOE-HDBK-3010-94).

Table A-2. Estimated Annual Release.

\begin{tabular}{|l|c|c|}
\hline \multicolumn{1}{|c|}{ Isotope } & $\begin{array}{c}\text { Unabated } \\
\text { Release, Curies }\end{array}$ & $\begin{array}{c}\text { Abated } \\
\text { Release, Curies }\end{array}$ \\
\hline Sr-90 & $4.12 \mathrm{E}-03$ & $4.12 \mathrm{E}-03$ \\
\hline $\mathrm{Pu}-239$ & $2.17 \mathrm{E}-01$ & $1.08 \mathrm{E}-04$ \\
\hline $\mathrm{Am}-241$ & $5.43 \mathrm{E}-02$ & $1.10 \mathrm{E}-04$ \\
\hline Total & $2.75 \mathrm{E}-01$ & $4.34 \mathrm{E}-03$ \\
\hline
\end{tabular}

\section{A11.0 OFFSITE IMPACT (Requirements 14 and 15)}

This section contains information regarding the estimated effective dose equivalents to the theoretical maximum exposed offsite receptor from unabated and abated emissions from the proposed activity. Attachment A-1 contains the information used to calculate the unabated and abated dose increases from the activities described in this Plan. Unit dose factors used in Attachment A-1 were derived using CAP88 (WHC 1991). The resulting offsite release and dose is provided in Table A-3 and Attachment A-1.

Table A-3. Estimated Annual Offsite Dose.

\begin{tabular}{|l|c|c|c|}
\hline \multicolumn{1}{|c|}{ Isotope } & $\begin{array}{c}\text { Unabated Dose, } \\
\text { millirem/year }\end{array}$ & $\begin{array}{c}\text { Abated Dose, } \\
\text { millirem/year }\end{array}$ & $\begin{array}{c}\text { Percent of } \\
\text { Offsite Abated } \\
\text { Dose }\end{array}$ \\
\hline Sr-90 & $1.07 \mathrm{E}-04$ & $1.07 \mathrm{E}-04$ & 7.1 \\
\hline Pu-239 & $1.12 \mathrm{E}+00$ & $5.59 \mathrm{E}-04$ & 36.7 \\
\hline Am-241 & $4.23 \mathrm{E}-01$ & $8.55 \mathrm{E}-04$ & 56.2 \\
\hline Total & $1.54 \mathrm{E}+00$ & $1.52 \mathrm{E}-03$ & 100.0 \\
\hline
\end{tabular}


Based on the regulatory limit of WAC 246-247, which includes all radioactive emission sources (point sources, diffuse and fugitive sources) in addition to radon 220 and 222, the dose resulting from all Hanford Site operations in 1996 was determined to be $3.9 \mathrm{E}-02$ millirem per year for an individual located at the Sagemore Farm (1,500 meters east of the 300 Area), (DOE/RL-97-43). Using the regulatory limit of $40 \mathrm{CFR} 61$, Subpart $\mathrm{H}$, which includes all sources and excludes radon 220 and 222, the estimated offsite dose to a receptor at the Sagemore farm was determined to be 2.0E-03 millirem per year.

The conservatively calculated abated offsite dose increase originating from the activities described in this Plan is 1.52E-03 millirem. The activities described in this Plan, in conjunction with other current operations on the Hanford Site, is within the National Emission Standard of 10 millirems per year.

\section{A12.0 COST FACTORS AND FACILITY LIFETIME (Requirements 16 and 17)}

Requirement 16 is not applicable because a best available radionuclide control technology (BARCT) demonstration is provided (Attachment A-3).

\section{A13.0 TECHNOLOGY STANDARDS (Requirement 18)}

Table A-4 summarizes the compliance of emissions control equipment for the breathing filters that will be installed on Tank 241-Z-361 and on the glovebags with the listed technology standards.

Table A-4. Emissions Control Equipment Standards Compliance.

\begin{tabular}{|l|l|}
\hline ASME/ANSI AG-1, as applicable & Yes \\
\hline ASME/ANSI N509, as applicable & Yes \\
\hline ASME/ANSI N510, as applicable & Yes \\
\hline ANSI/ASME NQA-1, 10 CFR 830.120, as applicable & Yes \\
\hline ANSI N13.1 & No \\
\hline 40 CFR 60 Appendix A Test Methods: 1, 1A 2, 2A, 2C, 2D, 4, 5, and 17 & No \\
\hline
\end{tabular}

The installed HEPA filters used for emissions abatement will be in a Flanders G1 housing or equivalent. Standards that will not be complied with are a result of using an alternative sampling method and passive ventilation system. 


\section{A14.0 REFERENCES}

10 CFR 830, "Nuclear Safety Management," Section 120, Quality Assurance Requirements, Code of Federal Regulations, as amended.

ANSI, 1994, Guide to Sampling Airborne Radioactive Materials in Nuclear Facilities, N13.1, American National Standards Institute.

ASME, 1989, Nuclear Power Plant Air-Cleaning Units and Components, N509, American Society of Mechanical Engineers, New York, New York.

ASME/ANSI, 1991, Code on Nuclear Air and Gas Treatment, AG-1, American Society of Mechanical Engineers, American National Standards Institute.

ASME, 1991, "Testing of Nuclear Air Treatment Systems", N510, American Society of Mechanical Engineers, New York, New York.

DOE/EH-0173T, Environmental Regulatory Guide for Radiological Effluent Monitoring and Environmental Surveillance, 1991, U.S. Department of Energy, Washington, D.C.

DOE/RL-97-43, Radionuclide Air Emissions Report for the Hanford Site, Calendar Year 1996,

U.S. Department of Energy, Richland Operations Office, Richland, Washington.

DOE-HDBK-3010-94, Airborne Release Fractions/Rates and Respirable Fractions for Nonreactor Nuclear Facilities, Volume 1, U.S. Department of Energy, Washington, D.C., December 1994, page 3-3.

HNF, 1997, Engineering Task Plan Cleanup of Miscellaneous Underground Storage Tank 241-Z-361, Rev. 1, HNF-SD-WM-ETP-208, SG Eurisys Services Corporation, Richland, Washington.

HNF, 1998, Justification for Continued Operation of Tank 241-Z-361, Rev. 0, HNF-2024, B\&W Hanford Company, Richland, Washington

WDOH, 1992, Letter, Air 92-107, A. W. Conklin, Washington State Department of Health, to

J. D. Bauer, U.S. Department of Energy, Richland Operations Office, no subject, October 5, 1992.

WHC, 1990, Deactivated Cribs and Settling Tanks, WHC-SD-SQA-CSA-20240, Westinghouse Hanford Company, Richland, Washington.

WHC, 1991, Unit Dose Calculation Methods Summary of Facility Effluent Monitoring Plan Determinations, WHC-EP-0498, Westinghouse Hanford Company, Richland, Washington. 
Figure A-1. The Hanford Site.

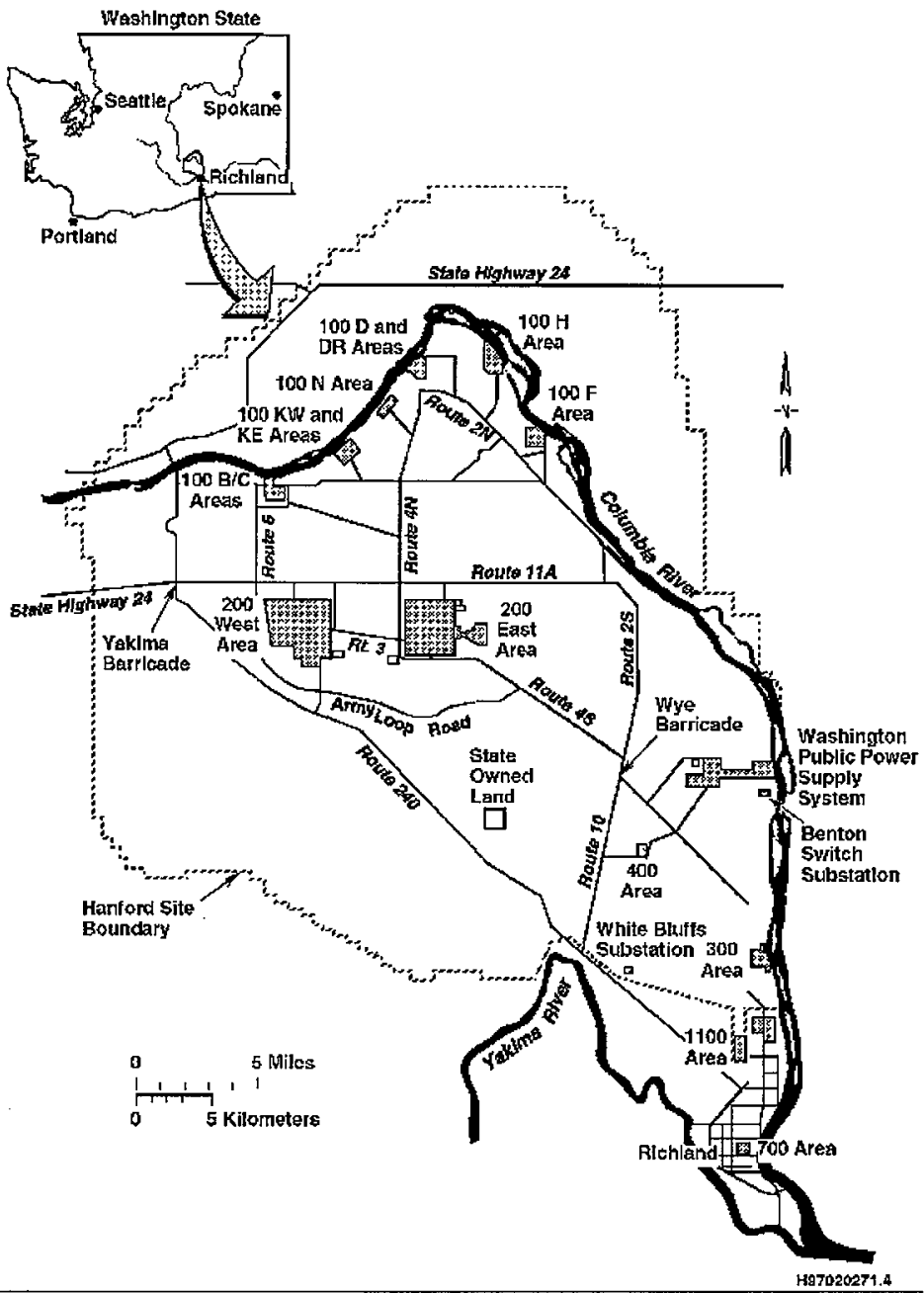


Figure A-2. Typical Video Camera and Sleeving.

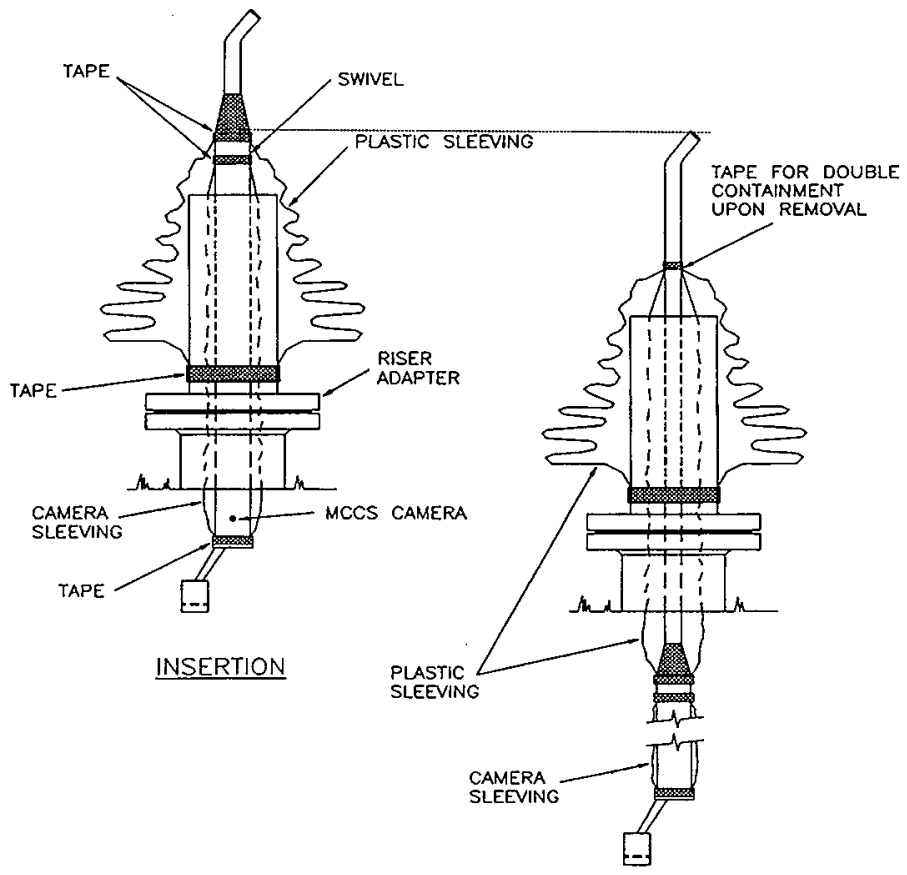




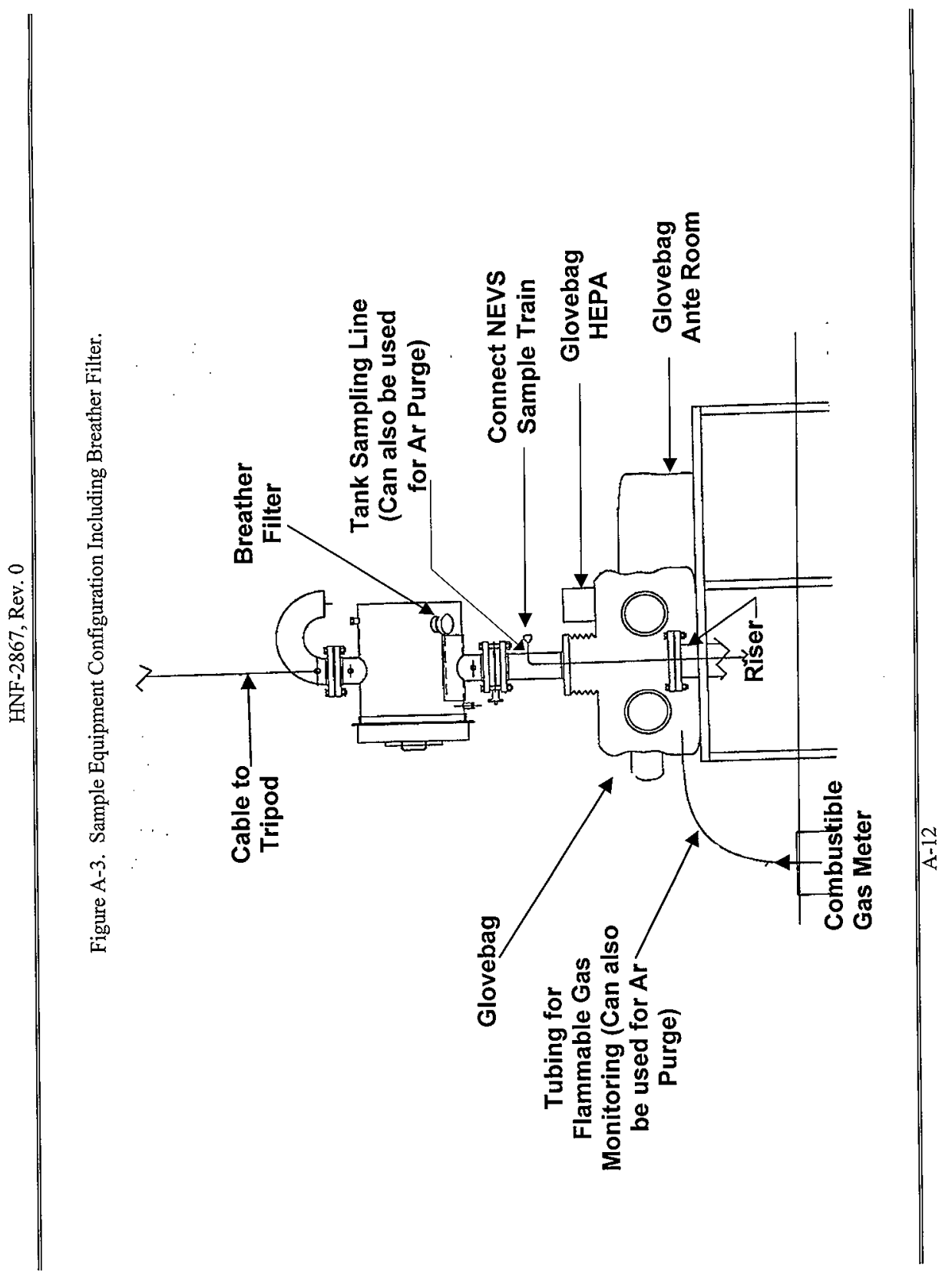


Figure A-4. Flow Diagram - Containment Structure Over Open Riser.

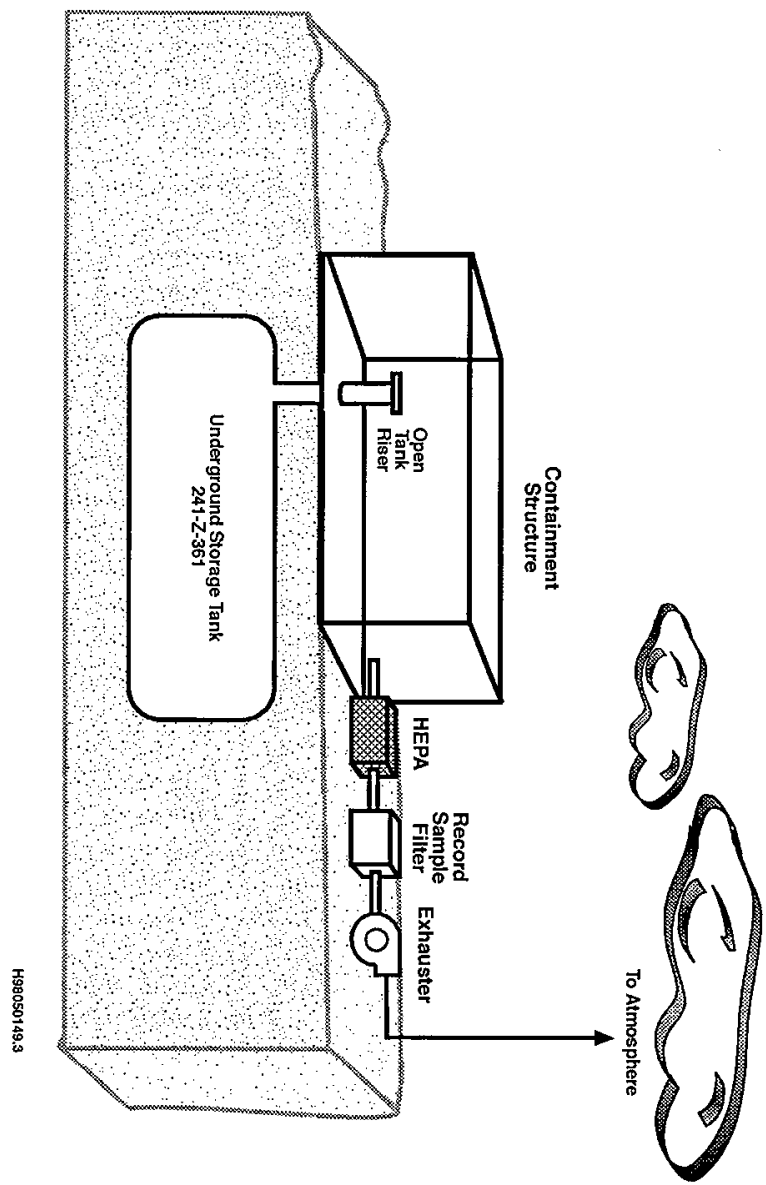


Figure A-5. Near Field Surface Monitor Locations Near UST 241-Z-361.

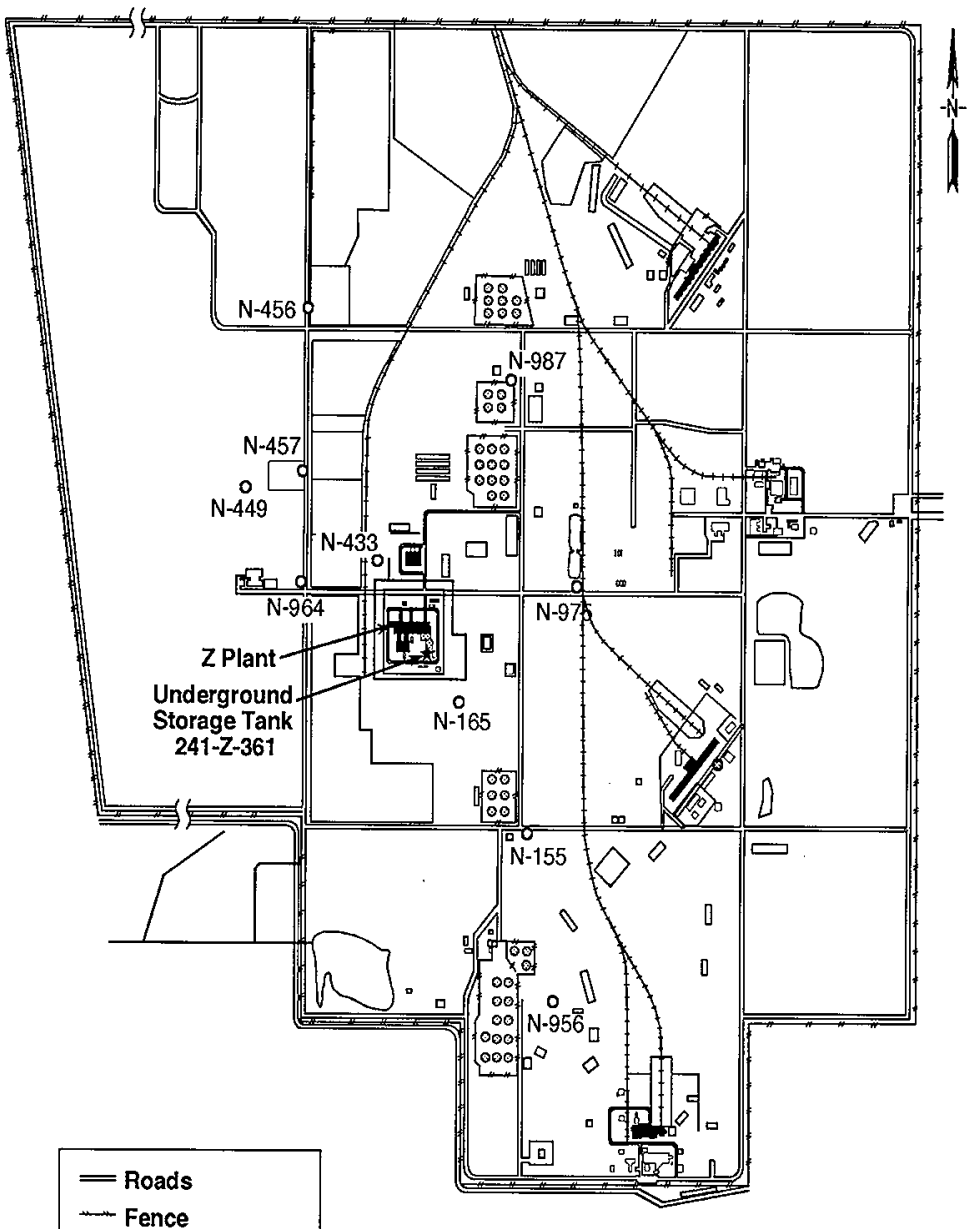




\section{ATTACHMENT A-1}

ESTIMATED ANNUAL POSSESSION QUANTITY UNDERGROUND STORAGE TANK 241-Z-361 
HNF-2867, Rev. 0

Potential To Emit Associated With Vapor Sampling, Purging, Installing Breather Filters On UST 241-Z-361

\begin{tabular}{|c|c|c|c|c|c|c|c|c|}
\hline Number Of HEPA Filters & 1 & & & & & & & \\
\hline HEPA Filter Efficiency & $99.95 \%$ & & & & & & & \\
\hline Release Fraction & $5.00 \mathrm{E}-05$ & \multicolumn{7}{|c|}{ (DOE-HDBK-3010-94, Page 3-3, Depressurization of Liquids at $0.35 \mathrm{MPa}$ or less) } \\
\hline Isotope & Quantity, Kg & $\begin{array}{l}\text { Total Possession } \\
\text { Quantity, Curies }\end{array}$ & $\begin{array}{l}\text { Unabated } \\
\text { Release, } \\
\text { Curies }\end{array}$ & $\begin{array}{l}\text { Abated } \\
\text { Release, } \\
\text { Curies }\end{array}$ & $\begin{array}{c}\text { Dose Conversion } \\
\text { Factor, Mrem/Curie } \\
\text { WHC-EP-0498 }\end{array}$ & $\begin{array}{c}\text { Unabated } \\
\text { Dose, Mrem }\end{array}$ & $\begin{array}{c}\text { Abated } \\
\text { Dose, Mrem }\end{array}$ & $\begin{array}{c}\text { Percent Of } \\
\text { Abated } \\
\text { Offsite Dose }\end{array}$ \\
\hline $\mathrm{Pu}-239$ & $7.00 \mathrm{E}+01$ & $4.34 \mathrm{E}+03$ & $2.17 \mathrm{E}-01$ & $1.08 \overline{\mathrm{E}}-04$ & $5.15 \mathrm{E}+00$ & $1.12 \mathrm{E}+00$ & $5.59 \mathrm{E}-04$ & $72.56 \%$ \\
\hline Am-241 & $3.16 \mathrm{E}-01$ & $1.09 \mathrm{E}+03$ & $5.43 \mathrm{E}-02$ & $2.71 \mathrm{E}-05$ & $7.79 \mathrm{E}+00$ & $4.23 \mathrm{E}-01$ & $2.11 \mathrm{E}-04$ & $27.44 \%$ \\
\hline TOTAL & $7.03 \mathrm{E}+01$ & $5.43 \mathrm{E}+03$ & 2.71E-01 & $1.36 \mathrm{E}-04$ & & $1.54 \mathrm{E}+00$ & $7.70 \mathrm{E}-04$ & $100.00 \%$ \\
\hline \multicolumn{9}{|c|}{ Potential To Emit Associated With Soil Excavation Activities } \\
\hline Maximum Soil Excavated & 1 & Yard $^{3}$ & & & & & & \\
\hline Maximum Soil Excavated & 27 & Feet $^{3}$ & & & & & & \\
\hline Soil Density & 95 & Pounds/Feet ${ }^{3}$ & \multicolumn{6}{|c|}{ (Average Packed Dry Earth, "Marks' Standard Handbook For Mechanical Engineers") } \\
\hline Total Mass Of Soil & $1.163 \mathrm{E}+06$ & Grams & & & & & & \\
\hline Maximum Alpha Reading & 5 & CPM & & & & & & \\
\hline $\begin{array}{c}\text { Maximum Beta/Gamma } \\
\text { Reading }\end{array}$ & 10,000 & CPM & & & & & & \\
\hline Release Fraction & $1.00 \mathrm{E}+00$ & & & & & & & \\
\hline Assumed Isotope & $\begin{array}{c}\text { Conversion } \\
\text { Factor } \\
\text { (pCi/Gram)/ } \\
\text { CPM }\end{array}$ & $\begin{array}{c}\text { Total Possession } \\
\text { Quantity } \\
\text { Curie }\end{array}$ & $\begin{array}{c}\text { Unabated } \\
\text { Release, } \\
\text { Curie }\end{array}$ & $\begin{array}{l}\text { Offsite Dose } \\
\text { Factor, } \\
\text { Mrem/Curie }\end{array}$ & $\begin{array}{l}\text { Unabated Dose, } \\
\text { Mrem }\end{array}$ & $\begin{array}{c}\text { Percent } \\
\text { Unabated } \\
\text { Offsite Dose }\end{array}$ & & \\
\hline Sr-90 & 0.35 & 4.12E-03 & $4.12 \mathrm{E}-03$ & $2.60 \mathrm{E}-02$ & $1.07 \mathrm{E}-04$ & $14.28 \%$ & & \\
\hline Am-241 & 14.20 & $8.26 \mathrm{E}-05$ & $8.26 \mathrm{E}-05$ & $7.79 \mathrm{E}+00$ & $6.44 \mathrm{E}-04$ & $85.72 \%$ & & \\
\hline TOTAL & & 4.205E-03 & $4.20 \mathrm{E}-03$ & & $7.51 \mathrm{E}-04$ & $100.00 \%$ & & \\
\hline
\end{tabular}

Notes:

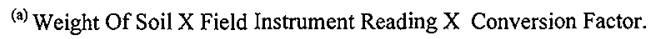

Summary Of Overall Potential To Emit

\begin{tabular}{|c|c|c|c|c|c|c|}
\hline Isotope & $\begin{array}{c}\text { Total Possession } \\
\text { Inventory, } \\
\text { Curies }\end{array}$ & $\begin{array}{c}\text { Unabated } \\
\text { Release, Curies }\end{array}$ & $\begin{array}{c}\text { Abated } \\
\text { Release, } \\
\text { Curies }\end{array}$ & $\begin{array}{c}\text { Unabated } \\
\text { Dose, Mrem }\end{array}$ & $\begin{array}{c}\text { Pbated Dose, Mrem } \\
\text { Abated } \\
\text { Offsite Dose }\end{array}$ \\
\hline Sr-90 & $4.12 \mathrm{E}-03$ & $4.12 \mathrm{E}-03$ & $4.12 \mathrm{E}-03$ & $1.07 \mathrm{E}-04$ & $1.07 \mathrm{E}-04$ \\
\hline Pu-239 & $4.34 \mathrm{E}+03$ & $2.17 \mathrm{E}-01$ & $1.08 \mathrm{E}-04$ & $1.12 \mathrm{E}+00$ & $5.05 \%$ \\
\hline Am-241 & $1.09 \mathrm{E}+03$ & $5.43 \mathrm{E}-02$ & $1.10 \mathrm{E}-04$ & $4.23 \mathrm{E}-01$ & $\mathbf{8 . 5 5 \mathrm { E } - 0 4}$ & $56.21 \%$ \\
\hline TOTAL & $\mathbf{5 . 4 3 E + 0 3}$ & $\mathbf{2 . 7 5 E}-\mathbf{0 1}$ & $\mathbf{4 . 3 4 \mathrm { E } - 0 3}$ & $\mathbf{1 . 5 4 E}+\mathbf{0 0}$ & $\mathbf{1 . 5 2 E}-\mathbf{0 3}$ & $\mathbf{1 0 0 . 0 0 \%}$ \\
\hline
\end{tabular}




\section{ATTACHMENT A-2}

\section{ALTERNATIVE METHOD FOR CONTINUOUS MEASUREMENT OF EMISSIONS UNDERGROUND STORAGE TANK 241-Z-361}

\section{Background}

I. Radionuclide Emissions from the Hanford Site

For the last 4 years, the total effective dose equivalent (TEDE) from radionuclide emissions has been at least three orders of magnitude below the annual 10 millirem limit in 40 CFR 61, Subpart $\mathrm{H}$. The annual calculated TEDE was $6 \mathrm{E}-03$ millirem for calendar year (CY) 1993, 5 E-03 millirem for CY 1994, 3 E-03 millirem for CY 1995, and 2 E-03 millirem for CY 1996.

II. Proposed Alternative for liquid/solid and vapor space sampling, videotaping, purging and venting Tank 241-Z-361 to atmosphere using a passively ventilated system.

Tank 241-Z-361 has an estimated radionuclide inventory of approximately 4,340 curies of plutonium-239 and 1,090 curies of americium-241. Estimated potential radionuclide emissions from the tank could cause a TEDE that exceeds 0.1 millirem per year to the maximum exposed offsite individual. As required by $40 \mathrm{CFR} 61$, Subpart $\mathrm{H}$, the emissions measurements need to be in conformance with the requirements of 61.93(b). Included in Section 61.93(b)4(i) is the statement: "With prior Environmental Protection Agency (EPA) approval, DOE may determine these emissions through alternative procedures." This alternative method is provided to meet the substantive requirements of 40 CFR 61, Subpart H.

Tank 241-Z-361 is a new source and the request for approval of the alternative method is consistent with requirements specified in 40 CFR Part 61.93(b)(3) for existing sources (before December 15, 1989). The requirements of 40 CFR 61.93(b)(3) are as follows:

"When it is impractical to measure the effluent flow rate at an existing source in accordance with the requirements of paragraph (b)(1) of this section or to monitor or sample an effluent stream at an existing source in accordance with the site selection and sample extraction requirements of paragraph (b)(2) of this section, the facility owner or operator may use alternative effluent flow rate measurement procedures or site selection and sample extraction procedures provided that:

(A) It can be shown that the requirements of paragraph (b)(1) or (2) of this section are impractical for the effluent stream;

(B) The alternative procedure will not significantly underestimate the emissions;

(C) The alternative procedure is fully documented;

(D) The owner or operator has received prior approval from EPA." 
As described in the following, the criteria to justify use of alternative methods can be demonstrated.

A. Requirements are Impractical

Tank 241-Z-361 initial characterization activities will include depressurization, sampling, purging and/or tank venting to atmosphere. These initial characterization activities will use passively ventilated HEPA filtered glovebags over the open risers. After completing the initial riser activities, any risers (minimum of one) that will remain open to atmosphere for subsequent tank venting will have HEPA breather filters installed. If a powered ventilation system with continuous emissions and flow monitoring were installed for the described activities, radionuclide emissions would increase. These increased emissions would be counter to as low as reasonably achievable (ALARA) guidelines.

To contain emissions for removal of the glovebag from the riser, a containment structure will be erected. The containment structure will be ventilated by a powered exhauster with an upstream HEPA. The containment structure will be in use for a relatively short period of time (less than one month). As a result, the cost of a continuous monitoring system for the containment structure is not justified.

B. Alternative Procedure will not Under Estimate Emissions

1. Particulate Emissions

The proposed alternative approach involves using a second in-line filter on the glovebag during depressurization, sampling, initial tank venting, and, if necessary, tank purging activities. In addition, a second in-line filter will be used on the breather filters that will be eventually installed on Tank 241-Z-361 and on the containment structure ventilation system. The second in-line filters will undergo a destructive or non destructive assay (NDA) to detect the gamma rays emitted from the decay of the Am-241, Pu-239, and Pu-240 isotopes using a gamma spectrometer. Because the entire passively exhausted flow is routed through the second in-line filter, all emissions are measured and accounted for. The assumption is made that whatever is on the second filter would be exhausted to the atmosphere. This results in a highly conservative estimate of emissions, and does not under estimate emissions. Since the second in-line filter will have a minimum efficiency of at least 90 percent efficiency for particles with a median diameter of 0.3 micron, better than 90 percent of the exhausted particulate material is expected to be collected on the filter. Assuming that all the material collected on the filter was exhausted is extremely conservative for estimating and reporting actual emissions. 


\section{Gaseous Emissions}

There are no measurable concentrations of gaseous radionuclides expected to be released. As a result, gaseous radionuclides would not contribute more than 10 percent of the offsite dose. Therefore, only particulate samples will be collected.

\section{Full Documentation of the Alternative Procedure}

The alternate procedure is that the second in-line filters will undergo destructive/ nondestructive analysis (NDA) to detect total alpha, total beta and total gamma emitters. The measurements will be done quarterly for the breather filter(s) and after use for the glovebag(s) and containment structure. The increase in radionuclide content of the second inline filters will be considered the emissions released over the period. The procedure includes the following.

1. Administrative controls are used to ensure a prompt response in the event emission levels increase beyond planned operation.

2. The samples are representative.

3. A $\log$ is maintained with the date of filter installation along with previous filter analysis results.

4. Routine verification of the sample data is performed.

5. The quality assurance program follows the onsite quality assurance program plan for radionuclide airborne emissions monitoring.

6. Aerosol testing is performed annually on the HEPA filter(s) to ensure the filter(s) maintain 99.95 percent removal efficiency of the radionuclide particulate emissions.

7. Laboratory detection limits of 1 microcurie are specified based on single isotope and no matrix interferences. Table A2-1 presents the off-site dose calculated based on 1 microcurie per isotope. The specified detection limits are 1 microcurie each for alpha, beta, and gamma, which corresponds to an off-site dose to the public (40 CFR 61.92). (Excluding soil excavation activities which will not result in emissions through the record filters, the SAP reported calculated off-site dose consequences of 1.54 and 7.7E-04 millirem/year, unabated and abated, respectively.) 
Table A2-1. Comparison of Detection Limits Versus Off-site Standards.

\begin{tabular}{|c|c|c|c|c|c|}
\hline $\begin{array}{c}\text { Laboratory } \\
\text { Reading }\end{array}$ & $\begin{array}{c}\text { Assumed } \\
\text { Isotope }\end{array}$ & $\begin{array}{c}\text { Detection Limit, } \\
\text { Curies }\end{array}$ & $\begin{array}{c}\text { Offsite Dose } \\
\text { Factor, } \\
\text { millirem/Curie }\end{array}$ & $\begin{array}{c}\text { Offsite Dose, } \\
\text { mrem/year }\end{array}$ & $\begin{array}{c}\text { Fraction of } \\
\text { 10 mrem/year } \\
\text { Standard }\end{array}$ \\
\hline Alpha & $\mathrm{Am}-241$ & $1.00 \mathrm{E}-06$ & 13.1 & $1.31 \mathrm{E}-05$ & $1.31 \mathrm{E}-06$ \\
\hline Beta & $\mathrm{Sr}-90$ & $1.00 \mathrm{E}-06$ & $4.38 \mathrm{E}-02$ & $4.38 \mathrm{E}-08$ & $4.38 \mathrm{E}-09$ \\
\hline Gamma & $\mathrm{Cs}-137$ & $1.00 \mathrm{E}-06^{*}$ & $2.39 \mathrm{E}-02$ & $2.39 \mathrm{E}-08$ & $2.39 \mathrm{E}-09$ \\
\hline Total & & $\mathbf{3 . 0 0 \mathrm { E } - 0 6}$ & & $1.32 \mathrm{E}-05$ & $\mathbf{1 . 3 2 \mathrm { E } - 0 6}$ \\
\hline
\end{tabular}

*A total alpha and beta analysis will be performed using a gas flow proportional counter or equivalent. Gama analyses will be determined using a gamma emission detector. 


\section{ATTACHMENT A-3}

\section{DISCUSSION OF BEST AVAILABLE RADIONUCLIDE CONTROL TECHNOLOGY (Requirement 16)}

Requirement 16 of WAC 246-247-060 is not applicable because BARCT emission equipment will be used. The BARCT is defined by WAC 246-247-030 as follows:

"Technology that will result in a radionuclide emission limitation based on the maximum degree of reduction for radionuclides from any proposed newly constructed or significantly modified emission units that the licensing authority determines is achievable on a case-by-case basis. A BARCT compliance demonstration must consider energy, environmental, and economic impacts, and other costs through examination of production processes, and available methods, systems and techniques for control of radionuclide emissions. A BARCT compliance demonstration is the conclusion of an evaluative process that results in the selection of the most effective control technology from all known feasible alternatives. In no event shall application of BARCT result in emissions of radionuclides that could exceed the applicable standards of WAC 246-247-040. Control technology that meets BARCT requirements also meets as low as reasonably achievable control technology requirements."

As stated in WAC 246-247-120, only those radionuclides comprising more than 10 percent of the unabated dose need to be evaluated. All of the dose is due to particulate radionuclides. The Washington State Department of Health has provided guidance that HEPA filters generally are considered BARCT for particulate emissions (WDOH 1992).

It is proposed, pursuant to the quoted citation, that the ventilation and systems (described in Section 8.0) and the controls (engineering and administrative) (described in Section 9.0) be approved as BARCT for the proposed activities at the Tank 241-Z-361. 


\section{APPENDIX B}

NON-RADIOACTIVE AIR MONITORING PLAN FOR CONTROLLING AND MONITORING EMISSIONS FROM VENTING, SAMPLING AND PURGING UNDERGROUND STORAGE TANK 241-Z-361 


\section{TABLE OF CONTENTS}

B1.0 PURPOSE.

B-1

B2.0 STATE ENVIRONMENTAL POLICY ACT (SEPA)

B3.0 FACILITY IDENTIFICATION AND LOCATION

B4.0 BACKGROUND INFORMATION

B5.0 PROJECT DESCRIPTION. .B-2

B6.0 VENTILATION AND AIRBORNE EMISSIONS POLLUTION CONTROL SYSTEM.

B7.0 AIRBORNE EMISSIONS MONITORING SYSTEMS …….........................................

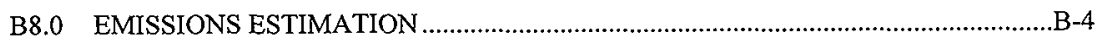

B8.1 SMALL QUANTITY EMISSION RATE ………...............................................

B8.2 PROCESS KNOWLEDGE USED TO ESTIMATED EXPECTED

AIRBORNE POLLUTANT EMISSIONS ………….........................................

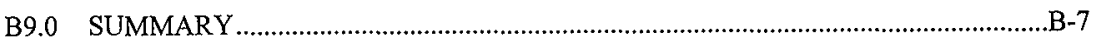

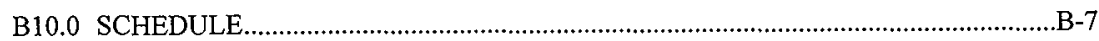

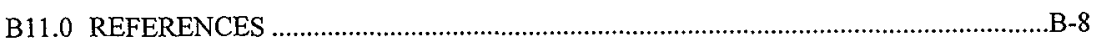

\section{FIGURE}

B-1 The Hanford Site.

B-9

\section{TABLES}

B-1 Tank 241-Z-361 Estimated Inventory of TAPs .........................................................

B-2 Expected Generation of Criteria Pollutants ...................................................................

\section{ATTACHMENT}

B-1. CALCULATION OF ESTIMATED EMISSIONS

Att-B1-1 


\section{B1.0 PURPOSE}

This appendix establishes the method of controlling and monitoring emissions for nonradioactive air emissions from the venting, purging and sampling of inactive Tank 241-Z-361. The plan demonstrates that the substantive requirements of Washington Administrative Code (WAC) 173-400 and 173-460 have been met.

\section{B2.0 STATE ENVIRONMENTAL POLICY ACT (SEPA)}

SEPA is not applicable since this action is being conducted under CERCLA.

\section{B3.0 FACILITY IDENTIFICATION AND LOCATION}

The activities described in this appendix will be performed outside towards the southeast corner of the Z-Plant security fence and within the 200 West Area of the Hanford Site (Figure B-1). The 200 West Area is approximately 25 miles northwest of the city of Richland, Washington. The latitude and longitude is as follows:

- Latitude: 46 degrees 32 minutes 57.3 seconds

- $\quad$ Longitude: 119 degrees 37 minutes 55.9 seconds

Address:

U.S. Department of Energy, Richland Operations Office $825 \mathrm{Jadwin}$ Avenue

P.O. Box 550

Richland, Washington 99352

The responsible manager's name and address are as follows:

Mr. L. D. Romine, Director

Transition Program Division

U.S. Department of Energy, Richland Operations Office

P.O. Box 550 MSIN R3-79

Richland, Washington 99352

(509) $376-4747$ 


\section{B4.0 BACKGROUND INFORMATION}

Between 1949 and 1973, Tank 241-Z-361 was used as a settling tank prior to discharging liquid effluent streams to the soil column. Tank 241-Z-361 received waste from the Plutonium Reclamation Facility (236-Z Building), Plutonium Finishing Plant (234-5Z Building) and the Incinerator Building (232-Z). The waste streams consisted of plutonium contaminated spent aqueous solutions, spent organic wastes, and non-contact cooling water. Lines into and out of Tank 241-Z-361 were blanked off in 1975 and the supernate pumped from the tank in the 1975 1977 time frame. In addition, all risers were sealed with blind flanges in 1985.

Tank 241-Z-361 has a nominal volume of 45,000 gallons (currently containing approximately 20,000 gallons of liquid/sludge) consisting of a steel lined rectangular concrete tank. The dimensions of Tank 241-Z-361 are $26 \mathrm{ft}$ in length, $13 \mathrm{ft}$ in width and a depth that slopes from 17 to $18 \mathrm{ft}$. The tank has an estimated liquid/sludge layer approximately $8 \mathrm{ft}$ deep (WHC 1990).

Because of previous isolation activities on Tank 241-Z-361, the tank has not been directly vented to atmosphere for the past 13 years. There is a possibility that the integrity of the tank has deteriorated; therefore, the tank may be venting to the soil column. Since the integrity of the tank is unknown, it has been assumed that the tank is pressurized due to the presence of hydrogen gas from radiolytic breakdown of water and remaining organic compounds.

The proposed activity will be a non-routine event that will potentially increase the rate of toxic air pollutants, fine particulate matter (PM-10) and total volatile organic compound (VOC) emissions.

\section{B5.0 PROJECT DESCRIPTION}

The activities within the scope of this application (proposed activities) will consist of venting, purging, and vapor space sampling of inactive Tank 241-Z-361.

Using HEPA filtered glovebags, one or two tank risers will be opened. A breather (HEPA) filter apparatus, will be installed on the first riser opened. The vapor space contents of the tank may be sampled to determine if the hydrogen concentration is close to or exceeds $25 \%$ of the LFL and to determine other chemical constituents that are in the vapor space.

In the event that the tank vapor space hydrogen concentration is close to or greater than $25 \%$ of the LFL for hydrogen, or will not passively ventilate to less than the LFL, the tank vapor space will be displaced by an inert gas (e.g., argon, carbon dioxide or other suitable gas) to displace the hydrogen in the tank vapor space to a concentration low enough to alleviate the concern of a 
hydrogen explosion. All tools used to install the breather filter apparatus and equipment to the tank risers will be nonsparking.

To aid in assessing the integrity of Tank 241-Z-361, the inside of the tank will be videotaped. Videotaping the inside of the tank will be accomplished by opening a riser, removing the blind flange or breathing filter apparatus, and inserting the video camera into the riser and down into the tank vapor space. After completing videotaping the inside of the tank, the video camera will be removed from the tank, decontaminated, if necessary, and a blind flange or breathing filter apparatus will be installed on the riser.

Further tank integrity assessments of Tank 241-Z-361 may be required. Additional assessments may include the need to excavate up to approximately 1 cubic yard of soil from above and along side the tank to visually and/or nondestructively evaluate the sidewall of the tank. Removal of the soil will be performed by hand excavation.

\section{B6.0 VENTILATION AND AIRBORNE EMISSIONS POLLUTION CONTROL SYSTEMS}

No controls are proposed for controlling emissions associated with TAPs. The proposal of no controls is based on low quantity of TAPs (see discussion in Section B8.0) available for release to atmosphere with minimal impact on the air quality if all TAPs were released, the high cost of control equipment for containing a minimal amount of TAPs (e.g., not cost effective), and the operating and disposal cost of control equipment once the identified tasks are completed.

Moisture (water) will be used as a pollution control measure during and after the excavation of soil to mitigate airborne particulate by controlling fugitive dust emissions, as required by WAC 173-400-040.

\section{B7.0 AIRBORNE EMISSIONS MONITORING SYSTEMS}

Should carbon tetrachloride amounts exceed the reportable quantity of $10 \mathrm{lb}$ over a 24 -hr period, the National Response Center will be notified in accordance with 40 CFR 302.6(a).

The expected emission rates and total quantity available for release is expected to be very low. The vapor space of the tank will be sampled to verify that the quantity of available TAPs to be released to the environment is low. A comparison will be made between the sample results and the estimates provided in Attachment B-1. Monitoring of carbon tetrachloride will be performed using Draeger Tubes since the estimated amount of carbon tetrachloride has been conservatively 
estimated to be close to the limit for small quantity emission rates. No monitoring is proposed for the remaining constituents. No monitoring for the remaining constituents is supported by the information contained within Section B8.0 which indicates that emissions will be sufficiently low to protect human health and safety, pursuant to WAC 173-460-070 and WAC 173-400 new source review requirements.

\section{B8.0 EMISSIONS ESTIMATION}

Pursuant to WAC 173-460-080 requirements, an acceptable source impact analysis is required for Class A and Class B TAPs. The emissions estimations provided in this subsection have been prepared for the purpose of satisfying WAC 173-460-080 acceptable source impact analysis and WAC 173-400 new source review requirements. Supporting calculations have been provided in Attachment B-1.

\section{B8.1 SMALL QUANTITY EMISSION RATE}

Pursuant to WAC 173-460-080(2)(e), the TAPS owner may use small quantity emission rates to demonstrate acceptable source impact analysis. The estimated emission rates are compared to the Small Quantity Emission Rate values listed in WAC 173-460-080. As indicated in Table B-1, the emission rates resulting from the proposed activities are not expected to exceed the WAC 173-460-080 Small Quantity Emission Rate values. The calculated estimated emission from carbon tetrachloride is 0.2 pounds less than the Small Quantity Emission Rate. To further demonstrate compliance for carbon tetrachloride, an estimated offsite concentration was calculated using dispersion factors generated from the EPA approved program ISC3 (EPA454/B-95-003a, Rittmann 1996). The acceptable source impact level at the site boundary for carbon tetrachloride is 0.067 micrograms per cubic meter. The calculated impact level for carbon tetrachloride at the site boundary is 0.006 micrograms per cubic meter, which is at least ten (10) times less than the acceptable source impact level.

The boiling point of carbon tetrachloride is $76.7^{\circ} \mathrm{C}$. At temperatures exceeding $76.7^{\circ} \mathrm{C}$, essentially all of the carbon tetrachloride would be vaporized. The temperature of 90 pounds per square inch (gauge pressure) steam to transfer liquid into tank $241-\mathrm{Z}-361$ was about $165^{\circ} \mathrm{C}$; therefore, the most of the carbon tetrachloride was probably vaporized. 
Table B-1. Tank 241-Z-361 Estimated Inventory of TAPs.

\begin{tabular}{|l|c|c|c|}
\hline \multicolumn{1}{|c|}{ TAP Constituent } & $\begin{array}{c}\text { TAPS } \\
\text { Class }\end{array}$ & $\begin{array}{c}\text { Estimated Worst Case } \\
\text { Total Quantity, } \\
\text { Pounds }\end{array}$ & $\begin{array}{c}\text { Small Quantity } \\
\text { Emission Rate, } \\
\text { Pounds/Year }\end{array}$ \\
\hline Benzene & $\mathrm{A}$ & 1.0 & 20 \\
\hline Carbon Tetrachloride & $\mathrm{A}$ & 19.8 & 20 \\
\hline Acetic Acid & $\mathrm{B}$ & 5.8 & 10,500 \\
\hline Oxalic Acid & $\mathrm{B}$ & 0.02 & 175 \\
\hline Dibutyl Phosphate & $\mathrm{B}$ & 36.9 & 1750 \\
\hline n-Butanol & $\mathrm{B}$ & 39.0 & 43,748 \\
\hline Tributyl Phosphate & $\mathrm{B}$ & 46.7 & 175 \\
\hline
\end{tabular}

The estimated quantity of TAPs was calculated under the following assumptions:

- liquid concentration of acetic and oxalic acid was equal to the amount of acid on an individual basis to achieve a $\mathrm{pH}$ of 4 ,

- Henry's Law is applicable for conservatively determining the partitioning between the liquid concentration and vapor space concentration,

- liquid waste stream is at low salt strength,

- liquid volume is equal to the sludge volume,

- liquid streams discharging to Tank 241-Z-361 with the potential to contain TAPs are at the solubility limit in water,

- TAPs constituent within the liquid portion of Tank 241-Z-361 was calculated to be equal to the solubility limit of water, multiplied by the total volume of flow that contained the TAPs constituent, and divided by the total volume of flow in Tank 241-Z-361,

- transfers were made to Tank $241-\mathrm{Z}-361$ at approximately $20^{\circ} \mathrm{C}$ instead of close to $100^{\circ} \mathrm{C}$,

- vapor space fraction is assumed to already exist in equilibrium with the calculated liquid concentration,

- total quantity of each TAP is equal to the sum of the TAP existing in the liquid and vapor phases, 
- the total quantity of calculated TAPs is released to the environment.

A higher salt strength and transfer temperature results in a higher fraction of TAPs that actually existed in the vapor space for released to the environment through the former tank vent.

The new source review of expected criteria pollutants is summarized in Table B-2 and compared to the exemption threshold limits of WAC 173-400-110(5)(d). Based on the comparison, the activities described are exempt from new source review under WAC 173-400 since the estimated emissions are less than the exemption threshold.

Table B-2. Expected Generation of Criteria Pollutants.

\begin{tabular}{|c|c|c|}
\hline Pollutant & $\begin{array}{c}\text { Estimated Emissions } \\
\text { (Tons/year) }\end{array}$ & $\begin{array}{c}\text { Exemption Threshold } \\
\text { Limit } \\
\text { (Tons/year) }\end{array}$ \\
\hline PM-10 & 0.001 & 0.75 \\
\hline VOC & 0.075 & 2.0 \\
\hline
\end{tabular}

The calculated criteria pollutants were calculated as follows:

- $\quad$ PM-10 estimated release was calculated based on hand excavation of soil using conservative 40 CFR 61 Appendix D release factor of $1 \times 10^{-3}$ with no abatement,

- The VOC estimated release was equal to the total amount of estimated TAPs within Tank 241-Z-361.

\section{B8.2 PROCESS KNOWLEDGE USED TO ESTIMATE EXPECTED AIRBORNE POLLUTANT EMISSIONS}

As discussed in Section B4.0, process knowledge exists regarding the TAPs and VOCs in Tank 241-Z-361, and this process knowledge was used to identify and screen TAPs and criteria pollutants with the potential to be present. A listing of these pollutants has been provided in Tables B-1 and B-2. 


\section{B9.0 SUMMARY}

This document serves as a TAPs monitoring plan for a new toxic air pollutant source. This document describes the proposed activities, identifies the conditions under which the activities will be performed, and estimates the impacts TAP emissions. This information is summarized below.

- The activities within the scope of this application (proposed activities) will consist of venting, purging, and sampling of inactive Tank 241-Z-361. The equipment and structures are potentially contaminated with TAPs, and proposed activities may increase the rate of TAP emissions.

- The applicant will perform sampling activities within the tank vapor space to verify the low quantities of TAPs after opening the tank riser.

- Due to the low quantity of TAPs, the applicant proposes no controls for TAP emissions.

- The applicant has conservatively estimated TAP emission rate increases from the proposed activities and has compared the estimates to applicable WAC 173-460 criteria. This comparison shows that the estimated emission rates are less than the WAC 173-460 criteria used for assessing impacts to human health and safety.

- The applicant has conservatively estimated the emission rate increase of criteria pollutants from the proposed activities and has compared the estimates to applicable WAC 173-400 criteria. This comparison shows that the estimated emission rates are less than the values in WAC 173-400-110(5)(d); therefore, this activity is exempt from new source review under WAC 173-400.

- The above discussion satisfies all relevant and applicable regulations for non-radioactive air emissions.

\section{B10.0 SCHEDULE}

The proposed activities are scheduled to be performed in September 1998, and will require approximately five weeks to complete. It should be noted that the activities may not necessarily be performed during five consecutive weeks. 


\section{B11.0 REFERENCES}

40 CFR 302.6(a), "Notification requirements," Code of Federal Regulations, as amended.

EPA-454/B-95-003a, User's Guide for the Industrial Source Complex (ISC3) Dispersion Models, September 1995.

WHC, 1990, Deactivated Cribs and Settling Tanks, WHC-SD-SQA-CSA-20240, Westinghouse Hanford Company, Richland, Washington.

DSI, P. D. Rittmann, to J. S. Hill, Unit Concentration Factors from ISC3, September 1996. 
Figure B-1. The Hanford Site.

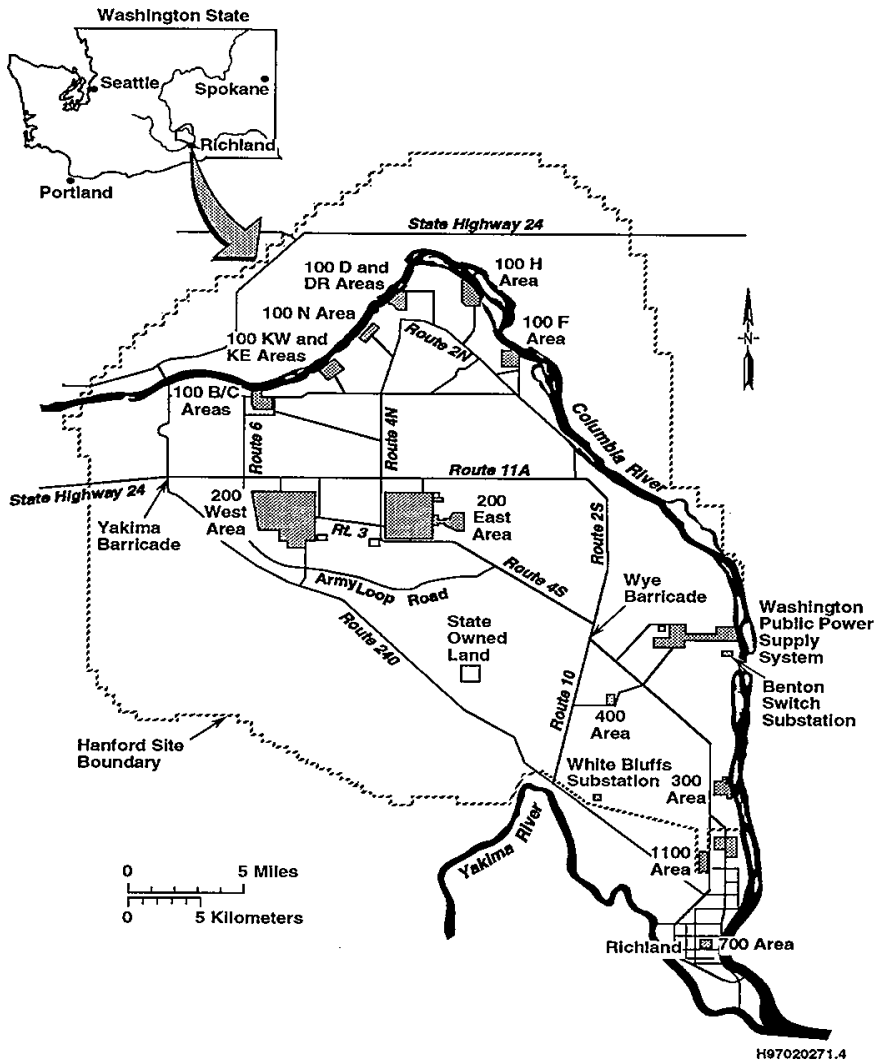


ATTACHMENT B-1

CALCULATION OF ESTIMATED EMISSIONS 
Estimation of total Toxic Air Pollutants (WAC 173-460) with the potential to be released during the sampling, purging and installation of breather filters on Tank 241-Z-361

$$
\begin{aligned}
& \text { ppm }:=\frac{1 \cdot \mathrm{gm}}{1 \cdot 10^{6} \cdot \mathrm{gm}} \quad \rho_{\text {water }}:=.997045 \frac{\mathrm{gm}}{\mathrm{cm}^{3}} \quad \mathrm{~T}:=(273+25) \cdot \mathrm{K} \\
& \mathrm{P}:=1 \cdot \mathrm{atm} \quad \quad \mathrm{R}_{\mathrm{gas}}:=82.057 \cdot \frac{\mathrm{atm} \cdot \mathrm{cm}^{3}}{\mathrm{~mole} \cdot \mathrm{K}} \quad \mathrm{mg}:=1 \cdot 10^{-3} \cdot \mathrm{gm} \\
& \mathrm{MW}_{\mathrm{H} 2 \mathrm{O}}:=(2 \cdot 1.0079+15.9994) \cdot \frac{\mathrm{gm}}{\mathrm{mole}} \quad \mathrm{MW} \mathrm{H}_{2 \mathrm{O}}=18.0150 \frac{\mathrm{gm}}{\mathrm{mole}}
\end{aligned}
$$

Assume sludge is $100 \%$ by volume of low salt strength water:

Volume $_{\text {liquid }}:=20000 \mathrm{gal} \quad$ Volume $_{\text {vapor }}:=25000 \mathrm{gal}$

For Carbon Tetrachloride (CCl4), $\mathrm{H}=$ Henry's Law Constant:

(Reference: Handbook of Physical Properties of Organic Chemicals, CRC Press)

$$
\begin{aligned}
& \mathrm{MW}_{\mathrm{CCl}}:=(12.011+4.35 .453) \cdot \frac{\mathrm{gm}}{\mathrm{mole}} \quad \mathrm{MW} \mathrm{CCl}_{4}=153.8230 \frac{\mathrm{gm}}{\mathrm{mole}} \\
& \mathrm{H}_{\mathrm{CCl} 4}:=2.76 \cdot 10^{-2} \cdot \frac{\mathrm{atm}^{3}}{\mathrm{~mole}} \text { Dilution_Factor } \mathrm{CCl} 4:=\frac{(174+86+54)}{2353} \\
& \mathrm{C}_{\text {CCl4_initial }}=.0024 \frac{\text { mole }}{\text { liter }} \quad \text { Dilution_Factor } \mathrm{CCl4}_{4}=0.133 \\
& \text { (Initial Carbon Tetrachloride Concentration from 15540-92-CAB-076) }
\end{aligned}
$$

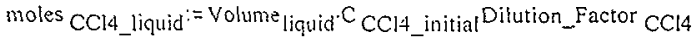

$$
\begin{aligned}
& \text { moles } \mathrm{CCl}_{2} \text { liquid }=24.247 \mathrm{~mol} \\
& \mathrm{C}_{\mathrm{CCl} 4}:=\frac{\text { moles } \mathrm{CCl} 4 \text { _liquid }}{\text { Volume }} \quad \mathrm{C}_{\mathrm{CCl} 4}=0.32 \cdot \frac{\mathrm{mole}}{\mathrm{m}^{3}} \\
& \mathrm{P}_{\mathrm{CCl} 4}:=\mathrm{HCCl}^{\mathrm{C}} \mathrm{CCl} 4 \quad \mathrm{P}_{\mathrm{CCl} 4}=8.8+10^{-3} \mathrm{oatm} \\
& \text { moles CCl4_vapor }:=\frac{P \text { CCl4 }{ }^{\text {Volume }} \text { vapor }}{R_{\text {gas }} \cdot T} \quad \text { moles } C C 14 \text { vapor }=34.21 \text { mole } \\
& { }^{W} \mathrm{CCl} 4 \text { total }:=\text { 'moles } \mathrm{CCl} 4 \text { _iquid }+ \text { moles } \mathrm{CCl} 4 \text { _vapor) } \cdot \mathrm{MW} \mathrm{CCl} 4 \\
& W_{i} \mathrm{CCl}_{-} \text {total }=19.8201 \mathrm{~b} \quad \mathrm{SQE} \mathrm{CCl}_{4}:=20 \cdot \frac{\mathrm{tb}}{\mathrm{yr}}
\end{aligned}
$$


The predicted Carbon Tetrachloride concentration is close to the SQE; therefore, will use dispersion modeling to verify that the offsite concentration is less than the ASIL. Offsite modeling was pertormed using dispersion factors from the ISC3 program (EPA-454/B-95-003a) based on runs performed by Rittmann (1996). In accordance with WAC 173-460-150, Table II. Carbon Tetrachloride has an ASIL value of 0.067 micrograms/meter 3 (annual average).

$$
\begin{aligned}
& \text { ASIL }_{\mathrm{CCl} / 4}:=067 \frac{\mu \mathrm{g}}{\mathrm{m}^{3}} \\
& \text { Concentration_Factor } 200 \mathrm{~W}:=.0585 \frac{\frac{\mathrm{\mu g}}{\mathrm{m}^{3}}}{\frac{\mathrm{gm}}{\mathrm{sec}}}
\end{aligned}
$$

Air_Concentration $\mathrm{CCl}_{4}:=\frac{\left(\mathrm{Wt} \mathrm{CCl}_{4} \text { total Concentration_Factor } 200 \mathrm{~W}\right)}{86400 \mathrm{sec}}$

Air_Concentration $\mathrm{CCl}_{4}=\frac{\mu \mathrm{g}}{\mathrm{m}^{3}}$

The predicted offsite air concentration is approximately 10 times less than the allowable offsite air concentration. 
For Acetic Acid ( $\mathrm{CH} 3 \mathrm{COOH}), \mathrm{H}=$ Henry's Law Constant, $\mathrm{S}=$ Total Solubility: (Reference: Handbook of Physical Properties of Organic Compounds, CRC Press)

$\mathrm{MW}_{\mathrm{AA}}:=(2 \cdot 12.011+4 \cdot 1.0079+2 \cdot 15.9994) \cdot \frac{\mathrm{gm}}{\mathrm{mole}} \quad \mathrm{MW}_{\mathrm{AA}}=60.0520 \frac{\mathrm{gm}}{\mathrm{mole}}$

$\mathrm{H}_{\mathrm{AA}}:=1.00 \cdot 10^{-7} \cdot \frac{\mathrm{atm} \cdot \mathrm{m}^{3}}{\text { mole }}$

Since acetic acid is disassociates in water, base estimation on reported $\mathrm{pH}$ of tank assuming contribution is attributed solely to acetic acid.

$$
\begin{aligned}
& \mathrm{pH}:=4 \quad \mathrm{H}_{\text {ion }}:=10^{-\mathrm{pl} 1} \cdot \frac{\text { mole }}{\text { liter }} \quad \mathrm{H}_{\text {ion }}=1 \cdot 10^{-4} \frac{\text { mole }}{\text { liter }} \\
& \mathrm{pK}_{\mathrm{a} \_\mathrm{AA}}:=4.76 \quad \text { (CRC Handbook of Chemistry \& Physics, } 78 \text { th } \\
& \text { Edition) } \\
& K_{a_{m} A A}:=10^{-\rho K_{a} A A} \quad K_{a_{-} A A}=1.73810^{-5} \\
& \text { moles AA_liquid := Acetic_Acid } \cdot \text { Volume }_{\text {liqquid }} \text { moles AA_liquid }=43.566 \text { mole } \\
& \mathrm{C}_{\mathrm{AA}}:=\frac{\text { moles } \mathrm{AA}_{-} \text {liquid }}{\text { Volume }_{\text {liquid }}} \quad \mathrm{C}_{\mathrm{AA}_{2}}=5.75410^{-4} \frac{\mathrm{mole}}{\text { liter }} \\
& P_{A A}:=H_{A A} \cdot C_{A A} \quad P_{A A}=5.75410^{-8} \text { gim } \\
& \text { moles AA_vapor }:=\frac{P_{A A} \cdot \text { Volume }_{\text {vapor }}}{R_{\text {gas }} \cdot T} \quad \text { noles } A_{A} \text { _vapor }=2.22710^{-4} \text { omole } \\
& \text { Wt AA_total : 'moles AA_liquid + moles AA_vapor; MWV AA } \\
& \text { Wt } A_{-} \text {total }=5.7680 \mathrm{lb} \quad S Q E_{A A}:=10500 \frac{\mathrm{lb}}{\mathrm{yr}}
\end{aligned}
$$


For Oxalic Acid (C2H2O4), $\mathrm{H}=$ Henry's Law Constant:

(Reference: Handbook of Physical Properties of Organic Chemicals, CRC Press)

$$
\begin{aligned}
& \text { MW }_{O A}:=(2 \cdot 12.011+2 \cdot 1.0079+4 \cdot 15.9994) \cdot \frac{\mathrm{gm}}{\text { mole }} \quad M_{O A}=90.0350 \frac{\mathrm{gm}}{\mathrm{mole}} \\
& \mathrm{H}_{\mathrm{OA}}:=1.43 \cdot 10^{-1} \cdot \frac{\mathrm{atm} \cdot \mathrm{m}^{3}}{\mathrm{~mole}}
\end{aligned}
$$

Since oxalic acid is disassociates in water, base estimation on reported oh of tank assuming contribution is attributed solely to oxalic acid.

$$
\begin{aligned}
& \text { pH }:=4 \quad \mathrm{H}_{\text {ion }}:=10^{-\mathrm{pll}} \cdot \frac{\text { mole }}{\text { liter }} \quad \mathrm{H}_{\text {ion }}=1 \cdot 10^{-4} \frac{\text { mole }}{\text { liter }} \\
& \text { PK a_OA }:=1.23 \quad \text { (CRC Handbook of Chemistry \& Physics, 78th } \\
& K_{a_{-} O A}:=10^{-p K_{a_{-} O A}} \quad K_{a_{-} O A}=0.059 \\
& \text { Oxalic_Acid }:=\frac{\mathrm{H}_{\text {ion }^{2}}}{\mathrm{~K}_{\text {a_OA } \mathrm{O} \frac{\mathrm{mole}}{\text { liter }}}} \quad \text { Oxalic_Acid }=1.69810^{-7} \frac{\text { mole }}{\frac{\text { moler }}{\text { liter }}} \\
& { }^{\text {moles }} \mathrm{OA}_{\text {_liquid }}:=0 x a \mathrm{lic} \text { _Acid } \cdot V_{\text {olume }} \text { liqquid } \quad \text { moles } \mathrm{OA}_{-} \text {liquid }=0.013 \text { mole } \\
& C_{O A}:=\frac{\text { moles } O A \_l i q u i d}{\text { Volume }_{\text {liquid }}} \quad C_{O A}=1.69810^{-7} \cdot \frac{\text { mole }}{\text { liter }} \\
& \mathrm{P}_{\mathrm{OA}}:=\mathrm{H}_{\mathrm{OA}} \cdot \mathrm{C}_{\mathrm{OA}} \quad \mathrm{P}_{\mathrm{OA}}=2.42810^{-5} \text { oatm } \\
& \text { moles } O A_{-} \text {vapor }:=\frac{P_{O A} \cdot \text { Volume vapor }}{R_{\text {gas }} \cdot T} \quad \text { moles } O A_{\text {_vapor }}=0.094 \text { mole } \\
& \text { Wt OA_total }:=\text { moles } \mathrm{OA}_{-} \text {liquid }+ \text { moles OA_vapor } \mathrm{MW} \text { OA } \\
& \text { Wt } \mathrm{OA}_{-} \text {total }=0.02101 \mathrm{~b} \quad \mathrm{SQE}_{\mathrm{OA}}:=175 \cdot \frac{\mathrm{lb}}{\mathrm{yr}}
\end{aligned}
$$


For Tributyl Phosphate [(C4H9O)3PO], $\mathrm{H}=$ Henry's Law Constant, $\mathrm{S}=$ Solubility in water by weight: (Reference: Handbook of Physical Properties of Organic Chemistry, CRC Press)

$$
\begin{aligned}
& \mathrm{MW}_{\mathrm{TBP}}:=(12 \cdot 12.011+27 \cdot 1.0079+4 \cdot 15.9994+1 \cdot 30.9738) \cdot \frac{\mathrm{gm}}{\mathrm{mole}} \quad \mathrm{MW}_{\mathrm{TBP}}=266.3170 \frac{\mathrm{gm}}{\mathrm{mole}} \\
& \mathrm{H}_{\mathrm{TBP}}:=1.50-10^{-7} \cdot \frac{\mathrm{atm} \cdot \mathrm{m}^{3}}{\text { mole }} \quad \mathrm{S}_{\mathrm{TBP}}:=2.8 \cdot 10^{2} \cdot \frac{\mathrm{mg}}{\text { liter }} \\
& \text { moles }{ }_{\text {TBP_liquid }}:=\frac{S_{\text {TBP }} \text { Volume liquid }}{W W_{T B P}} \quad \text { moles } \text { TBP_liquid }=79.598 \mathrm{~mol}^{\prime} \\
& \mathrm{C}_{\mathrm{TBP}}:=\frac{\text { moles TBP liquid }}{\text { Volume }_{\text {liquid }}} \quad \mathrm{C}_{\text {TBP }}=1.051 \cdot 10^{-3} \frac{\mathrm{mole}}{\text { liter }} \\
& \mathrm{P}_{\mathrm{TBP}}:=\mathrm{H}_{\mathrm{TBP}} \mathrm{C}_{\mathrm{TBP}} \quad \mathrm{P}_{\mathrm{TBP}}=1.57710^{-7} \mathrm{~atm} \\
& \text { moles TBP_vapor }:=\frac{P_{\text {TBP }} \cdot \text { Volume }_{\text {vapor }}}{R_{\text {gas }} \cdot T} \quad \text { moles } T B P_{\text {_vapor }}=6.10 ; 10^{-4} \text { omole } \\
& \text { moles TBP_total }:=\text { : moles TBP_liquid }+ \text { moles }{ }^{\text {TBP_vapor }} \text { moles } \text { TBP_total }=79.599 \mathrm{~mole}^{\circ} \\
& \text { Wt TBP_total }:=\text { moles } T B P_{-} \text {total }{ }^{-M W} \text { TBP } \\
& W t \text { TBP_total }=46.7350 \mathrm{lb} \quad S Q E_{T B P}:=175 \cdot \frac{\mathrm{lb}}{\mathrm{yr}}
\end{aligned}
$$


For Dibutyl Phosphate [(C4H9O)2POOH]:

$$
\mathrm{MW}_{\mathrm{DBP}}:=(8 \cdot 12.011+19 \cdot 1.0079+4 \cdot 15.9994+1 \cdot 30.9738) \cdot \frac{\mathrm{gm}}{\mathrm{mole}} \quad \mathrm{MW}_{\mathrm{DBP}}=210.21 \cdot \frac{\mathrm{gm}}{\mathrm{mole}}
$$

Each mole of TBP is capable of ultimately producing 1 moles of Dibutyi Phosphate through radiolytic decay. Assuming complete conversion of TBP to DBP:

$$
\begin{aligned}
& \text { moles TBP_total }=79.599 \mathrm{~mol} \\
& \text { moles DBP_total }:=1 \cdot \text { moles } \mathrm{TBP}_{-} \text {total moles } \mathrm{DBP}_{-} \text {total }=79.5990 \mathrm{~mole} \\
& \text { Wt DBP_total }:=\text { moles DBP_total }{ }^{- \text {MW }} \text { DBP } \\
& \text { Wt DBP_total }=36.889 \circ \mathrm{lb} \quad \mathrm{SQE}_{\mathrm{DBP}}:=1750 \frac{\mathrm{lb}}{\mathrm{yr}}
\end{aligned}
$$

For n-Butanol(C4H10O):

$$
\mathrm{MW}_{\text {Butanol }}:=(4 \cdot 12.011+10 \cdot 1.0079+15.9994) \frac{\mathrm{gn}}{\mathrm{mole}} \quad \mathrm{MW} \text { Butanol }=74.122^{\circ} \frac{\mathrm{gm}}{\mathrm{mole}}
$$

Each mole of TBP is capable of ultimately producing 3 moles of Butanol through radiolytic decay. Assuming complete conversion of TBP to Butanol;

$$
\begin{aligned}
& \text { moles } \text { TBP_total }_{-}=79.599 \mathrm{~mol} \\
& { }^{\text {moles }} \text { Butanol_total }:=3 \cdot \text { moles }{ }^{T B P} \text { tota! moles }{ }_{\text {Butanol_total }}=238.795 \text { mole } \\
& \text { Wt Butanol_total }:=\text { moles Butanol_total }{ }^{\text {NW }} \text { Butanol } \\
& W_{\text {Butanol_total }}=39.022 \% \mathrm{~b} \quad S Q E_{\text {Butanol }}:=43748 \frac{\mathrm{lb}}{\mathrm{yt}}
\end{aligned}
$$


For Benzene $(\mathrm{C} 6 \mathrm{H} 6), \mathrm{H}=$ Henry's Law Constant, $\mathrm{S}=$ Solubility in water by weight: (Reference: Handbook of Physical Properties of Organic Compounds, CRC Press)

$$
\begin{aligned}
& \text { MW Benzene }:=(6 \cdot 12.011+6 \cdot 1.0079) \cdot \frac{\mathrm{gm}}{\text { mole }} \quad \mathrm{MW}_{\text {Benzene }}=78.115^{\circ} \frac{\mathrm{gm}}{\text { mole }} \\
& \mathrm{H}_{\text {Benzene }}:=5.55 \cdot 10^{-3} \cdot \frac{\mathrm{atm} \cdot \mathrm{m}^{3}}{\text { mole }} \quad \mathrm{S}_{\text {Benzene }}:=1.79 \cdot 10^{3} \cdot \frac{\mathrm{mg}}{\text { liter }} \\
& \text { Dilution_Factor Benzene }:=\frac{6}{2353} \quad \text { Dilution_Factor Benzene }=2.5510^{-3} \\
& \text { moles Benzene_liquid }:=\frac{S_{\text {Benzene }} \cdot V_{\text {Volume }} \text { liquid } \cdot \text { Dilution_factor Benzene }}{M W_{\text {Benzene }}} \\
& \text { moles Benzene_liquid }=4.424 \mathrm{~mol} \\
& C_{\text {Benzene }}:=\frac{\text { moles Benzene_liquid }}{\text { Volume }_{\text {liquid }}} \quad C_{\text {Benzene }}=0.0580 \frac{\text { mole }}{\mathrm{m}^{3}} \\
& P_{\text {Benzene }}:=H_{\text {Benzene }} C_{\text {Benzene }} P_{\text {Benzene }}=3.24310^{-4} \text { atm } \\
& \text { moles Benzene_vapor }:=\frac{P_{\text {Benzene }} \cdot \text { Volume }}{\text { vapor }} . \quad \text { moles Benzene_vapor }=1.255^{\circ} \text { mole } \\
& \left.\mathrm{Wt}_{\text {Benzene_total }}:=\text { 'moles Benzene_liquid }+ \text { moles Benzene_vapor }\right) \cdot \mathrm{MW} \text { Bznzzne } \\
& W_{\text {Benzene }} \text { tont }=0.978 \mathrm{ol} \quad \quad S Q E_{\text {Benzene }}:=20 \cdot \frac{\mathrm{lb}}{\mathrm{yr}}
\end{aligned}
$$


Estimation of Criteria Pollutants (WAC 173-400):

$$
\begin{aligned}
& W_{\text {Acids }}:=W_{\text {AA_t }_{-} \text {tol }}+W_{t_{\text {OA_total }}} \quad W_{\text {Acids }}=5.78901 \mathrm{~b} \\
& W_{\text {Alcohol }}:=W_{\text {Butanol_total }} \quad \text { Wt } \text { Alcohol }_{\text {Als }}=39.022 \text { olb }
\end{aligned}
$$

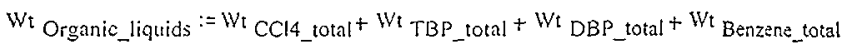

$$
\begin{aligned}
& \text { Wt VOC: }=\text { Wt Acids }+ \text { Wt Alcolol }+ \text { Wt Organic_liguids } \\
& \text { Wt } \text { VOC }=149.2361 \mathrm{~b} \quad \text { Wt VOC }=0.075 \text { oton Limit is } 40 \text { tonslyear }
\end{aligned}
$$

Assume Soil is all PM-10 Material:

$$
\begin{aligned}
& \text { Volume }_{\text {soil }}:=1 \cdot y d^{3} \\
& \rho_{\text {soil }}:=95 \cdot \frac{16}{\mathrm{ft}^{3}} \quad \begin{array}{l}
\text { (average density packed dry earth, "Marks' Standard Handbook for } \\
\text { Mechanical Engineers") }
\end{array} \\
& W_{\text {soil }}:=\text { volume }_{\text {soil }} \cdot P_{\text {soil }} \quad W_{\text {t }} \text { soil }=2.56510^{3} \text { olb } \\
& \text { For Hand Excavation using conservative } 40 \text { CFR } 61 \text { Appendix D } \\
& \text { release fraction of } 0.001 \text { : } \\
& \mathrm{PM}_{10}:=\mathrm{Wt}_{\text {soil }} .001 \quad \mathrm{PM}_{10}=1.163 \mathrm{~kg} \quad \mathrm{PM}_{10}=1.23310^{-3} \text { oton }
\end{aligned}
$$




\section{APPENDIX C}

\section{HEALTH AND SAFETY PLAN FOR PRELIMINARY CHARACTERIZATION TANK 241-Z-361}

This document is INCOMPLETE unless attached to the complete Sampling and Analysis Plan. 


\section{TABLE OF CONTENTS}

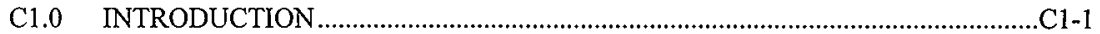

C1.1 FACILITY BACKGROUND .............................................................

C1.2 SCOPE

C1.3 DESCRIPTION OF PLANNED ACTIVITIES AT TANK 241-Z-361 ........C1-2

C1.4 METHODS OF CONTROLLING WORK ……............................................

C1.5 ROLES AND RESPONSIBILITIES.....................................................

C1.5.1 Management ........................................................................ C1-5

C1.5.2 Employees ................................................................................ C1-5

C1.5.3 Tank Waste Remediation System and Plutonium Finishing Plant Safety Management............................................... (1-5

C1.5.4 Tank Waste Remediation System and Plutonium Finishing Plant Safety Personnel.............................................. C1-5

C1.5.5 Tank Waste Remediation System and Plutonium Finishing Plant Radiological Control ......................................... C1-6

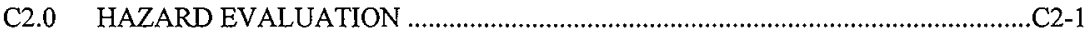

C2.1 TASK RELATED HAZARDS ASSOCIATED WITH

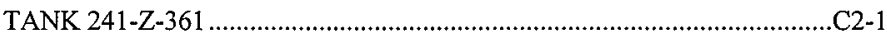

C2.2 POTENTIAL STRUCTURAL INSTABILITY OF TANK 241-Z-361........C2-2

C2.3 FIRE AND EXPLOSION HAZARD AT TANK 241-Z-361 ......................C2-2

C2.4 CHEMICAL AGENTS POTENTIALLY PRESENT IN

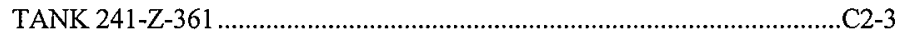

C2.5 PHYSICAL AGENTS ..................................................................... 22-5

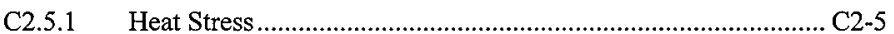

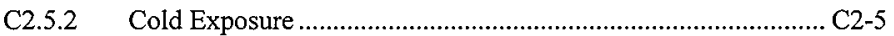

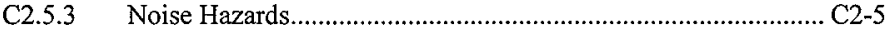

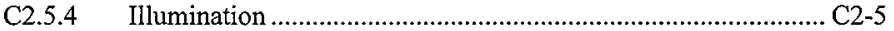

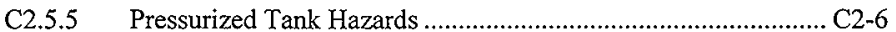

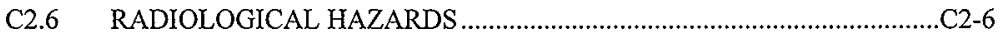

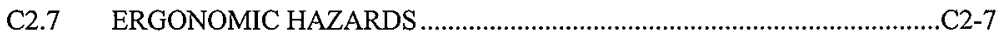

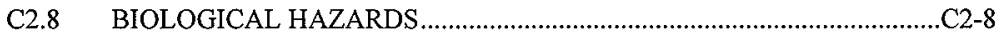

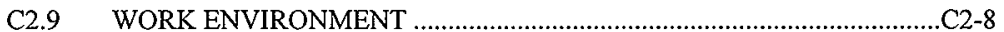

C2.9.1 Asbestos............................................................................... 2 2-8

C2.9.2 Walking/Working Surfaces .................................................... C2-9

C2.9.3 Working in Proximity to Moving Equipment/Vehicles ............. C2-9

C2.9.4 Machine Guarding ................................................................... C2-9

C2.9.5 Electrical Hazards.............................................................. C2-10

C2.9.6 Natural Hazards ................................................................ C2-10

C2.9.7 Stored Energy Sources/Lock and Tag .................................... C2-10

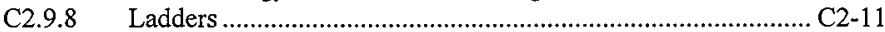

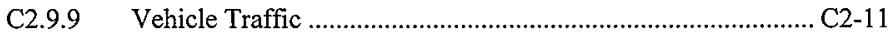

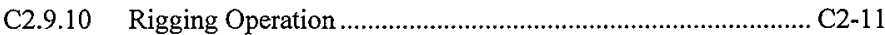

C2.9.11 Hand and Portable Power Tools ............................................. C2-11 
C2.9.12 Pinch Points....................................................................... C2-11

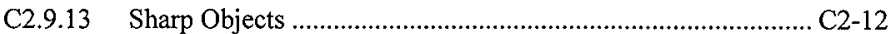

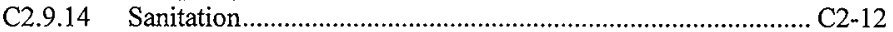

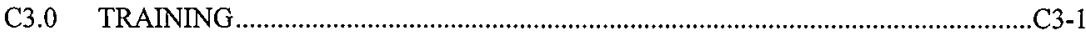

C3.1 GENERAL OVERVIEW .................................................................

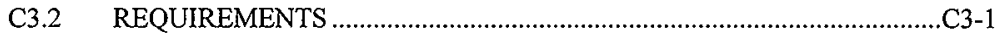

C3.3 TANK WORKERS ..............................................................................

C3.3.1 Upgrading of Worker Status.................................................... C3-3

C3.3.2 Equivalent Training............................................................... 3 3-3

C3.3.3 Refresher Training ...................................................................... C3-3

C3.4 ONSITE MANAGEMENT AND SUPERVISORS........................................ $3-3$

C3.5 HEALTH AND SAFETY STAFF ………............................................... $3-3$

C3.6 VISITORS, REGULATORS, AND OTHERS ……........................................ $3-4$

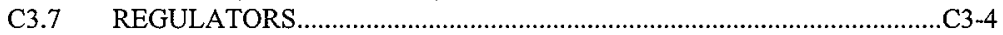

C3.8 RECORD OF TRAINING ……..................................................

C4.0 PERSONAL PROTECTIVE EQUIPMENT …….........................................................

C4.1 PERSONAL PROTECTIVE EQUIPMENT SELECTION

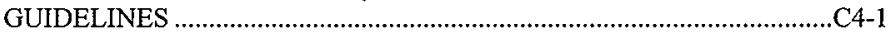

C4.2 LEVEL D PERSONAL PROTECTIVE EQUIPMENT ……............................ 4-1

C4.3 LEVEL C PERSONAL PROTECTIVE EQUTPMENT.................................C4-2

C4.4 LEVEL B PERSONAL PROTECTIVE EQUIPMENT....................................-2

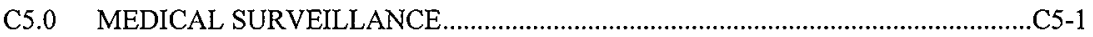

C5.1 MEDICAL EXAMINATIONS ........................................................... 55-1

C5.2 PERIODIC MEDICAL EXAMINATION ……........................................ 5-1

C5.3 FOLLOW-UP EXPOSURE PHYSICAL .................................................... 5-2

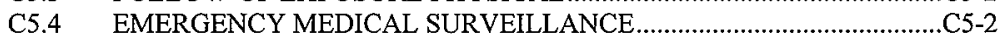

C5.5 RECORD KEEPING............................................................................ $5-3$

C5.6 BLOODBORNE PATHOGEN EXPOSURE CONTROL................................5-3

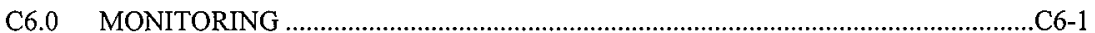

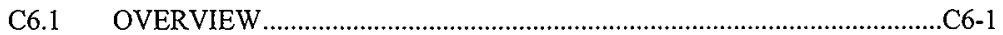

C6.2 WORK ACTIVITY MONITORING ……...............................................6-1

C6.2.1 Personal Monitoring ……………………................................. C6-2

C6.2.2 Area Monitoring …………….................................................... C6-2

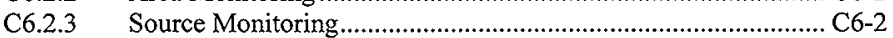

C6.3 SAMPLING AND MONITORING EQUIPMENT ………..............................6-2

C6.4 SAMPLING COLLECTION AND ANALYSIS ...............................................6-2

C6.5 MONITORING DATA REVIEW AND ACTION ….....................................6-2

C6.6 DETERMINING FACTORS FOR MONITORING AND

RESPIRATORY PROTECTION REQUIREMENTS ....................................C6-4

C6.6.1 Monitoring Methods and Respiratory Protection....................... C6-4

C6.6.2 Monitoring Methods and Compounds of Concern..................... C6-4

C6.6.3 Personal Sampling ...................................................................... C6-6 


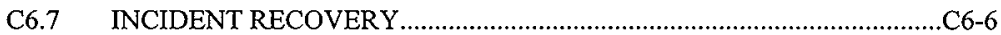

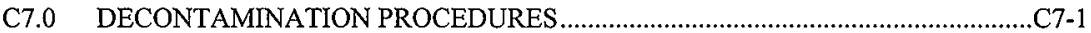

C7.1 PREVENTING CONTAMINATION ........................................................ 7-1

C7.1.1 Minimizing Contamination ..................................................... C7-1

C7.1.2 Proper Dressing Procedures .................................................... C7-2

C7.1.3 Personal Protective Equipment Checks...................................... C7-2

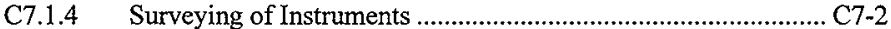

C7.2 TYPES OF CONTAMINATION.............................................................

C7.2.1 Physical States of Contaminants .............................................. C7-3

C7.2.2 Liquids and Gases ................................................................ C7-3

C7.2.3 Breakthrough Time................................................................... C7-3

C7.3 POLICIES FOR DECONTAMINATION PROCEDURES .........................C7-4

C7.4 POLICIES FOR SPECIFIC DECONTAMINATION PROCEDURES .......C7-4

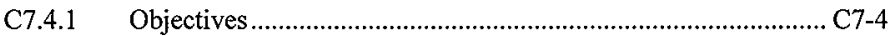

C7.4.2 Decontamination Required ..................................................... 7 7 4

C7.4.3 Health and Safety of Decontamination …………………….... C7-5

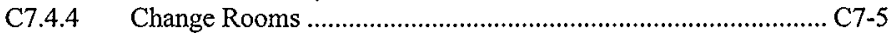

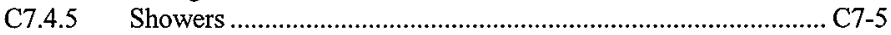

C7.5 TESTING FOR DECONTAMINATION EFFECTIVENESS ......................C7-5

C7.5.1 Visual Observation................................................................. $7-5$

C7.5.2 Wipe-Testing/Direct Reading Sampling ………...................... C7-5

C7.5.3 Testing for Permeation ............................................................ C7-6

C7.6 HEALTH AND SAFETY HAZARDS ........................................................... 7-6

C7.7 DECONTAMINATION EQUIPMENT SELECTION .................................. 7-6

C7.8 DISPOSAL METHODS............................................................................ 7-6

C7.9 PERSONAL PROTECTION ……............................................................

C7.9.1 General Safe Work Practices................................................... C7-6

C7.9.2 Protection of Decontamination Personnel ................................ C7-7

C7.10 EMERGENCY DECONTAMINATION .........................................................7-7

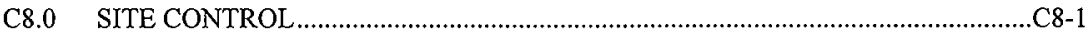

C8.1 RADIOLOGICAL CONTROL AREAS ..................................................... 8-1

C8.2 CONTAMINATION/AIRBORNE RADIOACTIVITY CONTROL

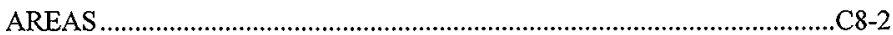

C8.3 HAZARDOUS WASTE OPERATIONS/ CLEANUP WORK ZONES .......C8-2

C8.3.1 Exclusion Zone....................................................................... 88-3

C8.3.2 Contamination Reduction Zone.................................................. C8-3

C8.3.3 Support Zone .................................................................... 88-3

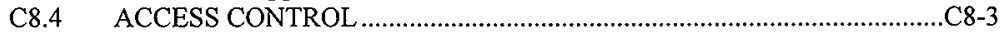

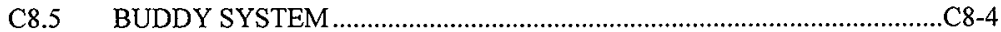

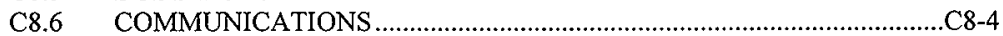

C9.0 EMERGENCY RESPONSE PLAN .................................................................... 
C10.0 CONFINED SPACE ENTRY POLICIES, GUIDELINES, AND REQUIREMENTS.

C11.0 ENVIRONMENTAL PROTECTION AND RESPONSE ….....................................11-1

C11.1 SMALL CONTROLLED SPILLS ............................................................ 11-1

C11.2 LARGE CONTROLLED/UNCONTROLLED SPILLS.................................11-1

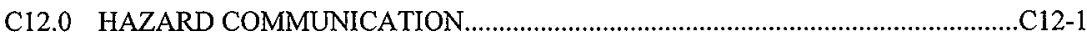

C12.1 HAZARDOUS CHEMICAL INVENTORY ............................................. $12-1$

C12.2 PHYSICAL AND BIOLOGICAL HAZARD INVENTORY ....................... $12-1$

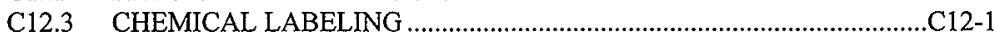

C12.4 MATERIAL SAFETY DATA SHEETS ……........................................... 12

C12.5 HAZARDS TRAINING..........................................................................

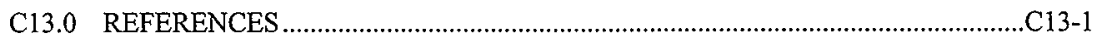

\section{ATTACHMENTS}

C-1 TANK 241-Z-361 SITE-SPECIFIC SUMMARY INFORMATION ......................Att-C1-1

\section{TABLES}

C2-1 Flammability Limits for Vapors of Concern, Tank 241-Z-361................................. C2-3

C2-2 Characteristics of Volatile Waste Constituents, Tank 241-Z-361 ............................. C2-4

C6-1 Chemical Agents-Monitoring Tool. ........................................................................... C6-3

C6-2 Physical Agents-Monitoring Tool........................................................................... C6-3

C6-3 Action Levels for Industrial Hygiene Monitoring Readings ........................................ C6-5

C6-4 Summary of Toxic Vapor Monitoring Requirements.................................................... C6-5 


\section{TERMS}

ACES

ACM

APR

BWHC

CERCLA

CFR

CGM

DOE

FDH

HASP

HAZMAT

HEPA

HPT

HSRCM

JCS

JCO

JHA

LFL

LMHC

MSDS

NIOSH

OHE

OSHA

OVM

PAM

PEL

PFP

PHMC

PIC

PPE

PWO

RCRA

RL

RWP

SAP

SCBA

S/RID

SWP
Access Control Entry System

asbestos-containing material

air-purifying respirators

Babcock and Wilcox Hanford Corporation

Comprehensive Environmental Response, Compensation, and Liability Act of 1980

Code of Federal Regulations

combustible gas meter

U.S. Department of Energy

Fluor Daniel Hanford, Inc.

health and safety plan

hazardous materials

high-efficiency particulate air (filter)

Health Physics Technician

Hanford Site Radiological Control Manual

Job Control System

Justification for Continued Operations

Job Hazard Analysis

lower flammability limit

Lockheed Martin Hanford Corporation

Material Safety Data Sheet

National Institute of Occupational Safety and Health

Occupational Health Examiner

Occupational Safety and Health Administration

organic vapor meter

personal air monitor

permissible exposure limit

Plutonium Finishing Plant

Project Hanford Management Contractors

person-in-charge

personal protective equipment

physician's written opinion

Resource Conservation and Recovery Act of 1976

U.S. Department of Energy, Richland Operations Office

Radiation Work Permit

Safety and Analysis Plan

self-contained breathing apparatus

Standards/Requirements Identification Document

safe work practice 
TLV

Tri-Party Agreement TWRS

UFL

WAC threshold limit value

Hanford Federal Facility Agreement and Consent Order Tank Waste Remediation System upper flammability limit

Washington Administrative Code 


\section{C1.0 INTRODUCTION}

This site-specific health and safety plan (HASP) has been developed to address health and safety requirements for conduct of Phase I characterization of Tank 241-Z-361. The Phase I activities are limited to opening the tank, collecting vapor samples from the tank headspace, and inserting cameras to record the characteristics of the tank interior. This HASP is provided in order to minimize health and safety risks to workers and other onsite personnel. This HASP accomplishes this objective by establishing requirements, providing general guidelines, and conveying facility-specific hazard communication information. This HASP is provided also as a reference for use during the planning of work activities at Tank 241-Z-361. This HASP is intended to provide information consistent with HNF-SD-WM-HSP-002, Tank Farm Health and Safety Plan (LHMC 1998).

The main body of this appendix is organized according to subject matter and presents first, the site-specific information relating to Tank 241-Z-361, followed by general information relevant for the planning and conduct of work. This information establishes baseline health and safety requirements and provides general guidelines. Supplemental information is provided in attachments to this HASP. A summary of site-specific health and safety requirements relevant to Tank 241-Z-361 is presented in Attachment C-1.

\section{C1.1 FACILITY BACKGROUND}

Tank 241-Z-361 is an inactive underground tank within the protected area of the Plutonium Finishing Plant (PFP) at the Hanford Nuclear Reservation near Richland, Washington. It is located approximately $240 \mathrm{ft}$ south of Building $236-\mathrm{Z}$.

Tank 241-Z-361 served as a primary solids settling tank for low-salt liquid (primarily aqueous) waste from Buildings 234-5Z, 236-Z, and 242-Z. Historic flows during the operating history of the tank were approximately $2,000,000 \mathrm{gal} / \mathrm{yr}$ of process wastewater. The supernatant from Tank 241-Z-361 was routed to the 216-Z-1A tile field and the 216-Z-1, 216-Z-2, 216-Z-3, and 216-Z-12 Cribs for disposal to ground. The tank was in service from 1949 until 1973, supernatant was removed in 1975 and the tank sealed in 1985. All tank inlet and outlet pipes and risers have remained sealed since that time, leaving a layer of sludge sediments approximately 94 in. deep in the bottom of the tank.

The tank is known to contain a substantial quantity of plutonium. The tank is expected to contain an estimated inventory of plutonium ranging from 30 to $70 \mathrm{~kg}$, based on the results of limited sampling and analysis conducted in the 1970 s and evaluation of the limited available historic waste stream information. In addition to plutonium, the tank contents are expected to include constituents from nearly all PFP processes used during the tank's 24-year operational period, but will be dominated by the nonsoluble components of effluents from Buildings $232-Z$, 234-5Z, and 236-Z. The exact nature of the solids remaining in the tank is not well described currently. The largest expected contributors of settleable solids and insoluble liquids are expected to have been ash from incinerator scrubber operations, excess acid and caustic salts 
from waste neutralization activities, and solvents (e.g., carbon tetrachloride) from plutonium recovery and refining operations and laboratory disposal. Additional background information on Tank 241-Z-361 is presented in Section 1.0 of this Safety and Analysis Plan (SAP).

\section{C1.2 SCOPE}

The characterization activities at Tank 241-Z-361 are being conducted as part of the Hanford Site remedial activities under the Comprehensive Environmental Response, Compensation, and Liability Act of 1980 (CERCLA). The requirements for health and safety planning, training, and safe field operations are specified by Occupational Safety and Health Administration (OSHA) Code of Federal Regulations (CFR), 29 CFR 1910.120, "Hazardous Waste Operations and Emergency Response."

This HASP applies to Lockheed Martin Hanford Corporation (LMHC), Babcock and Wilcox Hanford Corporation (BWHC), other prime contractors to the U.S. Department of Energy (DOE), and subcontractors to LMHC or Project Hanford Management Contractors (PHMC) who will conduct characterization activities at Tank $241-Z-361$. It has been prepared in recognition of, and is consistent with, National Institute of Occupational Safety and Health (NIOSH), OSHA, United States Coast Guard, U.S. Environmental Protection Agency, Occupational Safety and Health Guidance Manual for Hazardous Waste Site Activities (NIOSH 1985); Project Hanford Occupational Health and Safety Procedures; Washington Administrative Code (WAC) 296-62, Part P, "Hazardous Waste Operations and Emergency Response;" 29 CFR 1910.120; and Project Hanford Management Policies and Procedures. When differences in governing regulations or policies exist, the more stringent requirements shall apply until the discrepancy can be resolved.

The characterization of Tank 241-Z-361 involves cleanup under the CERCLA or past-practice sites listed in the Hanford Federal Facility Agreement and Consent Order (Tri-Party Agreement) (Ecology et al. 1994) is outside the normal tank farm operations. Over and above the requirements of 29 CFR 1910.120(p), LMHC has directed that in certain areas/circumstances additional precautions will be taken and respiratory protection zones established. The areas and circumstances are identified in the body of this document.

\section{C1.3 DESCRIPTION OF PLANNED ACTIVITIES AT TANK 241-Z-361}

The objectives of the current activity at Tank $241-Z-361$ are as follows:

1. Provide chemical analysis of tank vapors for use in defining safety requirements for future intrusive sampling.

2. Provide observational data to support evaluation of tank contents.

3. Provide observational data and limited measurement data to support engineering evaluation of the structural integrity of the tank. 
To meet these project objectives, the following activities will be implemented. Field activities are described in detail in Section 2.0 of this SAP. The site will be prepared prior to beginning the sampling activity. The site preparation activities will be conducted by BWHC staff under a separate planning package. Any changes to this plan based on the results of the load test and initial radiological survey will be incorporated as a safety plan amendment prior to initiating the sampling and analysis activities. Site preparation will include a structural evaluation and load testing of the tank roof, preparation of the tank top for access based on the results of the structural assessment (e.g., build work bridge or establish load limits), and a preliminary radiological survey of the work site.

Task 1: $\quad$ Open the Selected Tank Riser, Relieve Internal Pressure, and Monitor the Tank Atmosphere.

1. Establish an exclusion zone with a weather shelter around the tank work area, a contamination reduction area, and a support area.

2. Place a glovebag with high-efficiency particulate air (HEPA) filter system over the riser selected for vapor sampling.

3. Perform field monitoring for flammable vapors, toxic substances, and ionizing radiation.

4. Vent tank to glovebag, continue monitoring for flammable gas concentrations.

5. Allow the tank pressure to equilibrate to ambient.

6. Install the breather filter.

Task 2: $\quad$ Conduct the Investigative Activities.

1. Collect a representative sample of the tank vapor.

2. Contain and open a second and third (if necessary) tank riser for insertion of video cameras and lights into the tank. Close the risers when videography is complete.

Task 3: Decommission the Work Area.

1. Containerize all radiologically- or chemically-contaminated investigationderived waste.

2. Dismantle and remove all structures (e.g., weather shelter), temporary barriers, and support facilities. 
All work will be performed by employees of the PHMC companies. PFP operations staff will provide plant-specific training to Tank Waste Remediation System (TWRS) staff and will manage emergency response requirements.

Field work is planned and performed using a team composed of Operations, Maintenance, Health Physics, Engineering, Quality, and Safety personnel. This team is responsible for work package planning and preparation; completion of corrective maintenance, surveillance, and calibration field activities; as well as support to project and characterization activities.

The planned activities at Tank 241-Z-361 will be managed, operated, and maintained in a safe, healthful, and efficient manner. All activities will be conducted within the bounds of this appendix and in compliance with all applicable federal, state, and local regulations as mandated through the approved Plutonium Finishing Plant (PFP) Standards/Requirements Identification Document (S/RID) (WHC 1996).

\section{C1.4 METHODS OF CONTROLLING WORK}

To facilitate the timely performance of the characterization effort at Tank 241-Z-361, the Phase I effort will be conducted in a manner similar to routine work at the 200 Areas Tank Farms. For detailed information on Job Control System (JCS) implementation, refer to the HNF-IP-0842, TWRS Administration (WHC 1992).

Work control for the tank 241-Z-361 activities will follow TWRS most formal method of performing maintenance work, HNF-IP-0842 (WHC 1992) with a detailed resolution, which is approved before performance of the work. The hazards evaluation necessary to protect the worker is covered by the use of the Job Hazard Analysis (JHA) process described in Section C2.0 of this appendix.

Jobs for which performance of work is hazardous, very complex, or has a higher potential of adversely affecting the environment or equipment operability may require more details in planning. Jobs in these categories may also require additional approvals, stricter control of release to work and more control/overview during work. These complex or high-risk jobs are sent to the work package preparers for detailed planning. The requirements associated with work package approvals are described in HNF-IP-0842 (WHC 1992).

\section{C1.5 ROLES AND RESPONSIBILITIES}

Organizational roles, responsibilities, and interfaces are described in charters and program plans. Specific individual responsibilities are described in position descriptions. The organizational responsibilities for this activity are shared between staff of TWRS and PFP. Key management personnel are identified in Section 3.0 of this SAP. An overview of responsibilities for both organizations and personnel key to worker safety and health is described below. 


\section{C1.5.1 Management}

TWRS management is responsible for ensuring all work is properly prioritized and planned, and then executed in a safe manner. In addition, management shall ensure that the project staff possesses skills and resources necessary to safely conduct their assigned tasks.

\section{C1.5.2 Employees}

TWRS employees are responsible for ensuring all work is conducted in a safe and healthy manner and that safety and health concerns are reported and understood. Employees shall report unsafe conditions or practices to their direct supervisor or the job supervisor/person-in-charge (PIC) during work performance. Employees have the authority and should stop work if an immediate threat to life or health exists. When appropriate, employees should take personal action to correct or mitigate the unsafe condition at the time it is discovered. Employees are responsible for following all written procedures, controls specified in permits (e.g., Confined Space Entry Permit and Radiation Work Permit [RWP]), and additional safety instructions contained in work control documents or conveyed by the job supervisor/PIC.

\section{C1.5.3 Tank Waste Remediation System and Plutonium Finishing Plant Safety Management}

The TWRS Safety Manager is responsible for ensuring close coordination between project staff and the organization for the purpose of maintaining a safe and healthful workplace. Other responsibilities include developing and implementing this HASP and auditing field activities, as appropriate, to verify compliance; ensuring the effective integration and involvement of safety and health professionals in daily activities to ensure hazards are identified and controlled; supporting the line organization in dealing with hazards and establishing safety and health requirements through the PFP S/RID (WHC 1996). PFP safety management will provide daily inspections and weekly field safety oversight during field operations at Tank 241-Z-361.

\section{C1.5.4 Tank Waste Remediation System and Plutonium Finishing Plant Safety Personnel}

Personnel in the TWRS and PFP Safety organization are responsible for assisting management in defining and resolving safety and health issues; aiding in the communication of hazards to employees; providing evaluations of hazards; verifying compliance with this HASP; and assisting TWRS personnel to ensure all designated health and safety procedures and requirements are properly implemented in the field. 


\section{C1.5.5 Tank Waste Remediation System and Plutonium Finishing Plant Radiological Control}

The Characterization Project Radiological Control organization is responsible for monitoring for radiological hazards, providing radiological survey maps to support work planning and performance, verifying compliance with established radiological procedures, and invoking stop-work authority for radiological hazards that could potentially jeopardize worker health and safety. PFP radiological control will advise with regard to PFP-specific radiological control evaluation. 


\section{C2.0 HAZARD EVALUATION}

Activities at Tank 241-Z-361 pose potential physical, chemical, environmental, and radiological hazards. The radiological hazard associated with Tank $241-Z-361$ is better characterized than the chemical hazards.

Personnel may be exposed to a variety of chemical, physical, biological, and ergonomic agents while working at Tank 241-Z-361. Worker exposure to hazards may result from contact with materials, use of equipment, or working conditions. These hazards must be identified, and personnel must be properly protected. The ongoing efforts identified above are aimed at reducing the risks of injury, property damage, or exposure to chemical or radioactive materials. Multiple hazards must be considered, such as vapor exposures; flammability; heat and cold stress; electrical hazards; excessive noise levels; encounters with snakes, spiders, and insects; poor lifting techniques; and slips, trips, and falls.

Project personnel from $\mathrm{LMHC}$ and BWHC work together to identify hazards at the work location. As hazards are identified and evaluated, controls are employed to eliminate or mitigate the potential risks. The measures employed are documented, and the documentation is then disseminated. This information on hazards is used for work location posting and for discussion at prejob safety briefings and safety meetings.

This section of the HASP provides information on safety and health hazards that may be present at Tank 241-Z-361.

\section{C2.1 TASK RELATED HAZARDS ASSOCIATED WITH TANK 241-Z-361}

Most physical hazards (e.g., flammable vapors, trip and fall hazards, vehicle hazards, lifting and moving material hazards, heat and cold stress) and chemical hazards (e.g., potential toxic vapors) associated with the planned vapor sampling of Tank 241-Z-361 are similar to hazards related to the tank farm operations routinely conducted by TWRS personnel. Field personnel should review the protocols in the following sections for additional information. Some unique hazards, or potential degree of hazard, have been identified at the Tank 241-Z-361 Site. Detailed discussion of the Preliminary Hazard Analysis for Tank 241-Z-361 is presented in the Justification for Continued Operation for Tank 241-Z-361 (PHMC 1998a). These hazards are as follows:

1. potential structural instability of the tank,

2. potential combustible gas hazards,

3. potential toxic vapor hazards,

4. mechanical hazards associated with a potentially-pressurized tank,

5. potential for release of alpha-emitting radionuclides, and

6. criticality hazards (a criticality event was found to be extremely unlikely). 
The highest likelihood of accident is linked to procedural errors. Specific procedures have been developed for opening Tank 241-Z-361 and they are expected to be very effective when followed. However, major problems can occur if operational errors are made (turning wrong valves, mixing incompatible materials, etc.). Tank related operations, including the characterization of Tank 241-Z-361, cannot be made fail-safe. Safety must continue to rely on a rigorous conduct of operations. This requires a heavy commitment to training and administrative enforcement of proper conduct.

\section{C2.2 POTENTIAL STRUCTURAL INSTABILITY OF TANK 241-Z-361}

Tank 241-Z-361 is a steel-reinforced concrete structure located completely underground. The nature of the waste solutions historically sent to the tank and the limited observations conducted in the 1970s indicate a concern for the continued structural integrity of the tank due to possible corrosion of the concrete and the steel reinforcing. Failure of the tank structure under a load could result in serious personnel injury, equipment damage or loss, and potential release of toxic and flammable vapors and alpha-emitting radionuclides to the atmosphere. In addition to the main tank structure, the riser pipes on the tank top, which are flanged pipes set in the concrete tank roof, are subject to corrosion and subsequent loss of integrity. The interim operating controls currently in place prohibit placing any personnel or equipment loads on the tank top. Prior to any sampling activities, PFP engineering staff will perform a load test of the tank top. An analysis of the tank risers has produced side, vertical, and torque load limits for the risers.

Selected TWRS management and/or field operation staff will be onsite to observe the performance of the load test and will review the test results. The results of the load test will be incorporated into the safety requirements of this site-specific HASP, as necessary. It is unlikely that load limits will restrict the access required for the vapor sampling and videography activities. The load test will produce either specified load limits for the tank top, or portions thereof, or a requirement for construction of a bridge structure to support personnel and equipment during sampling activities.

\section{C2.3 FIRE AND EXPLOSION HAZARD AT TANK 241-Z-361}

Based on the assumption that the tank is effectively sealed, the Justification for Continued Operation (JCO) (PHMC 1998a) indicates that Tank 241-Z-361 has the potential to contain flammable vapors. The flammable vapors, if present, are most likely to be hydrogen $\left(\mathrm{H}_{2}\right)$ and/or methane $\left(\mathrm{CH}_{4}\right)$ from chemical or radiological degradation of organic materials in the remaining sludge. There is also a possibility for ammonia $\left(\mathrm{NH}_{3}\right)$ to be present in the tank vapor. All of these compounds are lighter than air and, if present, will tend to accumulate in the upper portion of the tank and the tank risers. The potential flammable gas hazard will be managed by implementing the flammable gas mitigation procedures specified in the JCO (PHMC 1998a). The upper and lower flammability limits (UFL, LFL) for the most likely flammable compounds are shown in Table C2-1. 
Table C2-1. Flammability Limits for Vapors of Concern, Tank 241-Z-361.

\begin{tabular}{|l|c|c|c|c|}
\hline \multicolumn{1}{|c|}{ Compound } & $\begin{array}{c}\text { LFL } \\
\text { (\% in air) }\end{array}$ & $\begin{array}{c}\text { UFL } \\
\text { (\% in air) }\end{array}$ & $\begin{array}{c}\text { Autoignition } \\
\text { temperature ( }\end{array}$ & $\begin{array}{c}\text { Vapor density } \\
\text { (air }=1.0)\end{array}$ \\
\hline Hydrogen $\left(\mathrm{H}_{2}\right)$ & 4 & 75 & $1,075^{\circ} \mathrm{F}$ & 0.07 \\
\hline Methane $\left(\mathrm{CH}_{4}\right)$ & 5 & 15 & $1,000^{\circ} \mathrm{F}$ & 0.55 \\
\hline Ammonia $\left(\mathrm{NH}_{3}\right)$ & 15 & 28 & $1,204^{\circ} \mathrm{F}$ & 0.60 \\
\hline
\end{tabular}

LFL $=$ lower flammability limit.

$\mathrm{UFL}=$ upper flammability limit.

The atmosphere inside the glovebag will be monitored constantly using a calibrated combustible gas meter (CGM). An inert gas (e.g., argon) will be introduced as needed to maintain the flammable gas concentration below 25 percent LFL. The CGM will be calibrated per the manufacturer's recommendations and checked daily with a challenge gas. The procedures for mitigating flammable gases during tank intrusions are described in the following sections are based on TWRS tank farm procedures.

Until characterization is completed, the assumption is maintained that Tank 241-Z-361 has the potential for producing a flammable gas mixture in the tank headspace. During work involving breaking containment on this tank, monitoring is performed to verify headspace levels are less than 25 percent of the LFL.

Flammable liquids will be stored and dispensed from U.S. Department of Transportationapproved shipping containers or approved safety containers. The vapors given off from these liquids are above their flash point and; therefore, are susceptible to any ignition source. HNF-PRO-358, "Flammable/Combustible Liquids" (PMHC 1997j), provides the requirements for the use, storage, and handling of these liquids. Flammable liquids for the project are expected to be limited to motor fuel in vehicles and a portable generator. All refueling will be performed at the PFP fueling station.

\section{C2.4 CHEMICAL AGENTS POTENTIALLY PRESENT IN TANK 241-Z-361}

The possibility exists for accumulation of toxic vapors in Tank 241-Z-361 based on historic operations and the nature of the processes which contributed wastes to the tank. These compounds included strong mineral acids (e.g., nitric acid, sulfuric acid, hydrochloric acid, hydrofluoric acid), strong caustics (e.g., sodium hydroxide), a number of organic compounds (e.g., carbon tetrachloride; tri-, di-, and mono-butyl phosphate; di-butyl butyl phosphate; butanol; urea; lard oil; oxalic acid; acetic acid; benzene; and phthalic acid), some metals, and a limited number of radionuclides.

Most of the acids and caustics are expected to have reacted with each other or with other tank contents and are not expected to be present in un-ionized states. A sample of the sludge from the early 1970 s indicated a slightly acid pH of 4.0 . The metallic contents of the tank are most likely present as solids in the tank, with the largest quantity in the sludge at the tank bottom. 
The organic compounds with substantial vapor pressure are the contents most likely to present a toxic vapor hazard during the planned activities at Tank 241-Z-361. A list of the characteristics of the suspected waste constituents with vapor pressure greater than $1.0 \mathrm{~mm} \mathrm{Hg}$ (including ammonia) is shown in Table C2-2.

Table C2-2. Characteristics of Volatile Waste Constituents, Tank 241-Z-361.

\begin{tabular}{|l|c|c|c|c|}
\hline \multicolumn{1}{|c|}{ Chemical } & $\begin{array}{c}\text { Vapor pressure } \\
\text { (mm Hg) }\end{array}$ & $\begin{array}{c}\text { Exposure limit } \\
\text { (ppm in air) }\end{array}$ & $\begin{array}{c}\text { Ionization } \\
\text { potential } \\
(\mathbf{e V})\end{array}$ & $\begin{array}{c}\text { Vapor density } \\
\text { (air = 1.0) }\end{array}$ \\
\hline Ammonia & 10,340 & 25 & 10.18 & 0.6 \\
\hline Acetic Acid & 11 & 10 & 10.66 & 2.07 \\
\hline Benzene & 75 & 1 & 9.24 & 2.77 \\
\hline Butanol & 6 & 50 (ceiling) & 10.04 & 2.55 \\
\hline Carbon Tetrachloride & 91 & 2 & 11.47 & 5.5 \\
\hline Dibutyl Phosphate & 1 & 1 & not determined & $<1$ (estimated) \\
\hline Monobutyl Phosphate & $<$ l (estimated) & none established & not determined & $<1$ (estimated) \\
\hline Dibutyl-Butylphosphate & 1 (approximately) & none established & not determined & $<1$ (estimated) \\
\hline
\end{tabular}

Exposure limit is most conservative of OSHA PEL or NIOSH recommended exposure limit.

NIOSH $=$ National Institute of Occupation Safety and Health. PEL = permissible exposure limit.

OSHA = Occupational Safety and Health Administration.

With the exception of ammonia, the volatile organic compounds potentially contained in the tank have vapor densities of greater than 1.0 (i.e., they are more dense than air). The long quiescent period with the tank sealed (e.g., about 13 years) creates the potential for stratification of vapors within the tank headspace with the lightest compounds closest to the tank top. The proposed vapor sampling activities are expected to cause minimal disturbance of the tank headspace. The proposed in-tank photography, however, may disturb the tank vapors and result in a different mixture of vapors at the tank riser(s). Personnel should continue a rigorous real-time air monitoring protocol during all activities at Tank 241-Z-361.

Chemical exposure may occur through inhalation, absorption, ingestion, or injection.

- Inhalation of hazardous materials may occur from lack of, or improper use of, respiratory equipment, malfunctioning monitoring equipment, or the presence of either undetected chemicals or chemicals in quantities greater than respiratory equipment protection limits.

- Absorption through the skin or eyes of solid, liquid, or gaseous hazardous substances can occur by direct contact or through cuts and/or abrasions. Skin or eye absorption can occur when a worker does not wear the proper protective clothing or proper eye protection, when a break or a tear occurs in the protective clothing, or when unwashed hands come in contact with the eyes. 
- Exposure by ingestion might occur and affect the digestive system if hazardous substances are ingested by workers who do not practice good personal hygiene habits (e.g., washing hands thoroughly after completion of work or before smoking, eating, drinking, or chewing gum or tobacco).

- Hazardous substances may be injected into the body through puncture wounds while using contaminated equipment with sharp edges, from protrusions, pressurized hoses, or air lines.

\section{C2.5 PHYSICAL AGENTS}

The planned characterization of Tank 241-Z-361 is subject to all of the physical hazards associated with similar work at other tanks at the Hanford Site. The following discussion was developed directly for use at the Hanford tank farms and could apply to Tank 241-Z-361.

\section{C2.5.1 Heat Stress}

The Heat Stress Program for Tank 241-Z-361 characterization will follow the requirements of HNF-PRO-121, "Heat Stress Control" (PMHC 1997h), which appears in the Project Hanford Policy and Procedures System. Assistance in applying heat stress controls is available through Cognizant Industrial Hygienists.

\section{C2.5.2 Cold Exposure}

If schedule delays extend the project field work into cold weather, cold exposure management procedures will be implemented per the tank farms HASP.

\section{C2.5.3 Noise Hazards}

The identification and control of noise hazards, and the criteria for employee enrollment into the Hearing Conservation Program, will follow the requirements of HNF-PRO-115, "Hearing Conservation" (PMHC 1997g). The only noise source of potential concern for this project is a portable generator. If the specific generator used at the site exceeds noise standards, then appropriate hearing protection will be used.

\section{C2.5.4 Illumination}

Although field activities are expected to be performed during the day shift, personnel may encounter areas with inadequate lighting levels when working around Tank 241-Z-361. When there is concern of inadequate lighting, an illumination evaluation will be performed and improvements made to allow safe conduct of work activities. Improvements could include the location and use of portable lighting, dependent on the job-specific needs. 
Requirements for minimum illumination intensities (measured in foot-candles) have been established by 29 CFR 1910.120 . Areas accessible to employees shall be lighted to not less than the specified minimum intensities.

\section{C2.5.5 Pressurized Tank Hazards}

There is a potential for Tank $241-Z-361$ to contain substantial internal pressure due to the evolution of gases from evaporation and decomposition of tank contents. The assessment conducted as part of the JCO (PHMC 1998a) indicated a potential for internal tank pressure up to $15.5 \mathrm{lb} / \mathrm{in}^{2}$. Due to this potential for pressurization, specific steps will be taken to mitigate potential hazards associated with opening a pressurized tank. The primary hazards of opening a pressurized tank are:

1. Personnel injuries caused by the riser blind flange or other components that may be dislodged when the flange bolts are released; and

2. Rupture of the glovebag by overpressure and release of an excessive volume of vapors into the glovebag, with subsequent loss of containment by the glovebag.

These hazards will be mitigated primarily by implementing a planned effort to allow controlled release of pressure from the tank. This will be achieved by the following steps (these steps are described in detail in this $\mathrm{SAP}$ ):

1. Replacing the existing riser flange bolts and nuts, one at a time, with new, lubricated nuts and bolts of nonsparking material;

2. Placing the glovebag over the riser;

3. Loosening the flange bolts in a controlled and even manner and allowing the tank pressure to bleed off through either hypodermic needles inserted through the flange gasket, or through a small orifice in a steel band installed around the flange joint; and

4. Removing the riser blind flange only after all residual internal pressure in the tank has been relieved.

The atmosphere inside the glovebag and at the glovebag HEPA filter exhaust will be monitored continuously during the pressure release action to ensure that flammable vapors are kept below 25 percent LFL and that proper personal protective equipment (PPE) is in use.

\section{C2.6 RADIOLOGICAL HAZARDS}

Tank $241-Z-351$ is known to contain a substantial quantity of plutonium (e.g., 30 to $70 \mathrm{~kg}$ ) and is expected to contain some americium from radioactive decay of the plutonium (PHMC 1998a). The JCO documents extensive evaluation of a criticality event and has concluded that it is 
extremely unlikely to occur. Although most of the radionuclides in the tank are expected to be contained in the sludge at the tank bottom, some radioactive particles may be found in any portion of the tank, including on the tank sides, roof, and within the risers. It is possible for some fine-textured particulate material containing the nuclides of concern to be disturbed during tank opening and venting. These particulates may be suspended in the tank headspace and may, therefore, be discharged from the tank during pressure venting, opening, and insertion and removal of sampling equipment and cameras.

The potential release of, and exposure to, these radionuclides will be controlled through the use a HEPA filter-equipped glovebag during tank opening and vapor sampling, and through the use of PPE, including appropriate respiratory protection.

An RWP will be prepared for the activities at Tank 241-Z-361 to provide for Health Physics Technician (HPT) support during field operations. The field activities will require field monitoring for alpha, beta, and gamma radiation and evaluation of filter samples from the glovebag HEPA filter for the presence of alpha, beta, and gamma emitters. Action levels for ionizing radiation will be defined in the RWP.

The primary means of contamination control is containment. Areas where contamination has already spread are posted to warn personnel.

The RWP is used to govern all entries to radiation areas, all radiological work, and all storage of radioactive materials (see site forms A-6000-272 and A-6000-272.1).

\section{C2.7 ERGONOMIC HAZARDS}

The most common ergonomic hazard identified at the tank farms is use of backpack mounted self-contained breathing apparatus (SCBAs) and manual lifting of tools, equipment, or materials necessary to perform operations. This hazard could and has resulted in back injuries (the predominantly reportable injury in the tank farms).

The medical service provider provides a back injury prevention program emphasizing back strengthening and flexibility. Job hazard evaluation for Tank 241-Z-361 should consider the ergonomic risks. The following is a guide for manual lifting activities:

1. If available, use a material handling system when possible.

2. If the lifting activity occurs regularly, a material handling system or tool should be purchased (e.g., dolly, hoist, and spring-loaded cart).

3. Male employees lifting over $29.5 \mathrm{~kg}(65 \mathrm{lb})$, or female employees lifting over $20.4 \mathrm{~kg}$ (45 lb), should seek assistance from co-workers (one-time lift only, not repetitive). 
4. Employees who perform manual lifts should be instructed in proper lifting techniques (materials on manual lifting are available from the Shared Resource Center, listed in the Hanford Site phone directory).

5. Physical capabilities or limitations of potential employees should be considered. Any concerns about a potential employee's lifting ability should be discussed with the physicians at the medical service provider.

Ergonomics must also be a consideration in the design, development, and installation of new equipment, processes, and facilities. The most effective means for ensuring incorporation of ergonomic considerations is the involvement of both specialists and users in all phases of planning and installation/construction.

The glovebag/breather filer assembly will be mocked up prior to the field activities. Ergonomic issues will be evaluated and modifications made as necessary to reduce lifting and awkward operating positions.

\section{C2.8 BIOLOGICAL HAZARDS}

Snakes, scorpions, bees, and spiders may hide under or inside of equipment or in protective clothing storage areas. Workers disturbing them may be bitten or stung. The consequences of a bite or sting can be a severe reaction and, possibly death. If an injury from a biological hazard occurs, prompt medical aid must be requested and provided. Workers with known extreme reactions to bee stings should consider carrying an anaphylaxis emergency treatment kit and inform co-workers of the condition. Workers are advised to shake out all protective clothing before donning.

\section{C2.9 WORK ENVIRONMENT}

Hazards discussed in this section may be encountered in routine job activities performed at Tank 241-Z-361. Sections C2.9.1 through C2.9.14 reflect items for consideration during the JHA phase required for use in planning of nonroutine work activities.

\section{C2.9.1 Asbestos}

The flange gasket(s) on Tank 241-Z-361 risers are expected to contain asbestos and will be treated as asbestos-containing material (ACM). When working on or disturbing $\mathrm{ACM}$, controls as stated in HNF-PRO-408, "Asbestos - Facility Management/General Industry" (PMHC 1997k) or HNF-PRO-338, "Asbestos Control - Construction Industry" (PMHC 1997i), must be used and followed. An asbestos work permit, site form 54-6700-149, shall be completed before performing asbestos work. 
ACM might present an inhalation hazard if it becomes damaged and friable. Chronic (long-term) exposure can cause lung cancer, mesothelioma, digestive system cancer, and asbestosis. These risks are minimal when material is not disturbed.

Facilities with ACM have postings at each entrance, and known ACM is identified using ACM labels or pink coating. Only Washington State-certified asbestos workers may handle asbestos.

\section{C2.9.2 Walking/Working Surfaces}

The walking/working surfaces in the site present slip, trip, and fall hazards. Next to heat stress, this hazard has the highest potential (based on injury statistics) for causing harm to employees. Hazards that may exist include uneven terrain, guy wires, stairs, ramps, wind-blown soil, rocks, risers, conduit, ducts, well caps, electrical cords, and hoses. Additional risks from walking/working surface hazards are present during inclement weather or during the evening when illumination (lighting) in the site is minimal. Workers must be informed of these potential hazards during training and prejob briefings, in accordance with HNF-PRO-091, "Walking/ Working Surfaces" (PMHC 1997c).

\section{C2.9.3 Working in Proximity to Moving Equipment/Vehicles}

A variety of equipment present and operating near Tank 241-Z-361 including cranes, backhoes, personnel lifts, sample trucks, pickup trucks, and other vehicles. Spotters and/or signal persons must be used whenever there is a potential hazard from the movement or operation of machine or vehicle, in accordance with DOE-RL (1993) and HNF-PRO-100, "Transportation Safety" (PMHC 1997e).

Workers must pay close attention when working in areas where vehicles are operated. The drivers of vehicles must also be aware of people and obstacles around them. Where a driver has a limited view to the rear of the vehicle, a spotter must be used for backing. When cranes are operated, workers around the cranes must wear hard hats and never work or pass under lifted loads. Carbon monoxide is a potential hazard when working around internal combustion engines. If it is necessary to operate engines, sufficient ventilation must be allowed to prevent carbon monoxide inhalation.

\section{C2.9.4 Machine Guarding}

Those authorized to remove guarding for any purpose must follow HNF-IP-0842 (WHC 1992) and then immediately replace the guards when their work is complete, in accordance with HNFPRO-086, "Machine Guarding" (PMHC 1997b). Workers must be aware of these potential hazards and report them when observed so they may be properly guarded. 


\section{C2.9.5 Electrical Hazards}

Overhead power lines, downed electrical wires, and buried cables all pose the danger of shock or electrocution. Electrical equipment may also pose a hazard to workers. Careful observation for overhead electrical hazards shall be performed by operating personnel before raising masts on drill rigs, booms on cranes, or when operating any equipment capable of coming into contact with electrical wires. Workers must also look for frayed cables, uncovered openings in boxes and switch centers, and any other defects in electrical equipment. These hazards must be reported to the line manager as soon as they are observed.

\section{C2.9.6 Natural Hazards}

Because most work performed at Tank 241-Z-361 is done out-of-doors, many environmental factors need to be considered. As identified in Sections C2.5.1 and C2.5.2, heat and cold stress can be a problem for workers. Inclement weather can make walking/working surfaces slippery. In addition, rain or melting snow can fill in low areas in normal walkways, causing workers to take new routes, where they may encounter other hazards.

Thunderstorms and their resultant lightning are of particular concern at the tank farms. If lightning strikes more than $8 \mathrm{~km}(5 \mathrm{mi})$ away from the site, people can continue to work. If lightning strikes within $8 \mathrm{~km}(5 \mathrm{mi})$, they should leave the site; workers may return if no lightning strikes are observed within 30 minutes. If lightning is identified within a 50-mi radius of Tank 241-Z-361 intrusive activities will be stopped until the storm passes and no lightning strikes are observed for 30 minutes.

The impact of wind (dust storms/high winds with potential to resuspend contamination and reduce visibility) on work in outdoor areas containing nonfixed contamination will be controlled by the applicable RWP. Operations will determine additional precautions to be taken at Tank 241-Z-361 in high wind and predicted high-wind conditions.

\section{C2.9.7 Stored Energy Sources/Lock and Tag}

Stored energy sources pose a potential hazard to workers. These hazards include, but are not limited to, electrical, mechanical, hydraulic, pneumatic, chemical, radiation and thermal energies, and various forms of potential energy (e.g., springs, compressed gases, or suspended objects). Lockouts/tagouts shall be used to protect workers from these energy sources. The lockout/tagout procedures are described in HNF-IP-0842 (WHC 1992) and are controlled by the PFP shift supervisor. 


\section{C2.9.8 Ladders}

Ladders purchased and used at the Tank 241-Z-361 Site shall be appropriate for industrial applications and comply with the specifications of HNF-PRO-094 "Portable Ladders" (PMHC 1997d). Employees working with portable ladders shall know and follow established rules and safe practices for ladder use. Ladders shall be maintained in good condition at all times, inspected before each use, and stored properly.

\section{C2.9.9 Vehicle Traffic}

All vehicle drivers at Tank 241-Z-361 shall obey all posted signs and Washington State vehicle laws. Guidelines for transportation are provided in HNF-PRO-100 (PMHC 1997e). Vehicles are not allowed in the site unless the job requires the use of a vehicle. Vehicle movement near Tank 241-Z-361 is not allowed without approval of the shift manager and spotters to assist.

Pedestrians at the site shall be aware of all vehicle traffic and obey all safety rules.

\section{C2.9.10 Rigging Operation}

For operation, inspection, maintenance, and repair requirements for cranes, hoists, fork trucks, and rigging equipment, refer to DOE-RL (1993).

\section{C2.9.11 Hand and Portable Power Tools}

Employees who operate power tools shall be properly trained in the use of the equipment. Power tools should be operated in strict accordance with the manufacturer's instructions. Required PPE shall be worn as needed when operating power tools. The requirements and responsibilities for the use of power tools are located in HNF-PRO-085, "Hand and Portable Power Tools" (PMHC 1997a) and HNF-PRO-086 (PMHC 1997b).

\section{C2.9.12 Pinch Points}

During certain work activities at the Tank 241-Z-361 Site, a situation may arise exposing workers to moving machinery injury hazards. This situation may present a "pinch-point hazard." Pinch-point injury hazards can exist between unguarded rotating and fixed parts that create a shearing, crushing, or abrading action. For guidance of preventing pinch-point injuries refer to HNF-PRO-086 (PMHC 1997b). 


\section{C2.9.13 Sharp Objects}

Certain work activities in Tank 241-Z-361 investigations may expose workers to hazards involving sharp object injuries. Sharp objects can be encountered as a result of mechanical failure, in the course of using tools and machinery, and in handling discarded waste materials. For guidance in preventing injuries due to sharp objects, refer to site procedures and any applicable JHA.

\section{C2.9.14 Sanitation}

All work places shall be kept clean and housekeeping shall be monitored regularly. At the end of each task/job, the work area will be clean with all work materials, tools, and equipment returned to appropriate storage locations. Adequate potable water and toilet facilities shall be provided. 


\section{C3.0 TRAINING}

The training requirements for personnel conducting the activities at Tank 241-Z-361 are the same as for the tank farm operations typically conducted by these personnel, with the exception of plant-specific training for operations at PFP. The training requirements are described in the following sections.

\section{C3.1 GENERAL OVERVIEW}

Safety training is designed to provide workers with the necessary skills and knowledge to perform assigned duties and functions in a safe and healthful manner.

Training for personnel is dependent on the level and type of work each individual will be responsible for performing. At a minimum, each worker requires a general level of training to meet the OSHA requirements of both 29 CFR 1910.120 and 29 CFR 1910.1200, "Hazard Communication." Additional training that meets other regulatory requirements provides further safety and health training for tank farm operations (such as "Dangerous Waste Regulations" [WAC 173-303], Radiation Protection for Occupational Workers [DOE 1988]).

\section{C3.2 REQUIREMENTS}

All employees working onsite who may be exposed to hazardous substances, or health or safety hazards shall receive appropriate training. All managers are responsible for ensuring that a training program is in place and that employees are properly trained. Employees shall not be permitted to participate in or supervise field activities until they have been trained to a level required by their job function and responsibility. Worker qualification records are maintained by Fluor Daniel Hanford, Inc. (FDH) Training Records. Qualifications for entry into radiological control areas are verified through the Access Control Entry System (ACES), which includes the employee hazardous waste worker training information. Entry to radiological control areas will e denied if entry requirements are not met. For specific entry requirements, refer to HNF-IP-0842 (WHC 1992).

Tank Farm Facility Orientation and initial hazardous waste operations field experience received under escort will include discussion of applicable safe work practices (SWPs). Site-specific hazard communication information (i.e., signs, postings, maps, and SWPs) will be maintained for employee review at tank farm facilities and primary access points such as change trailers. As part of the entry process through the ACES stations, employees are required to acknowledge when they sign in that they have read and understand the applicable RWP. 
All field personnel working on the Tank 241-Z-361 project will participate in plant-specific training session provided by PFP staff prior to commencing work at the site. This plant-specific training includes, but is not limited to, the following topics:

- facility layout and location;

- emergency signals, notification, and communication;

- routes of egress and staging areas;

- plant-specific safety requirements; and

- plant emergency response procedures.

Participation in the plant-specific training will be documented and documentation retained in personnel training records. TWRS staff will make arrangements with PFP training personnel to obtain the necessary training in a timely manner which facilitates the field operations. Taskspecific hazards are covered during formal prejob briefings which are required when the specific hazards require a "Job Hazard Analysis" (HNF-PRO-079, PMHC 1998b).

\section{C3.3 TANK WORKERS}

Workers who have the potential for direct contact with tank wastes (hazardous waste workers) shall receive 40 hours of hazardous waste operations training, supplemented with a minimum of 3 days of actual field experience under the direct supervision of a trained, experienced supervisor. The program shall include annual 8 -hour refresher training.

Personnel requiring this level of training perform work that:

- directly contacts the tank headspace (breaking of tank containment),

- contacts tank waste or waste-contaminated materials, and

- directly involves operation or maintenance of installed tank farm equipment.

Typical tank farm activities include maintenance and operations of the existing facilities to ensure their continued integrity and safety. Specific activities include daily surveillance, equipment maintenance, waste transfers, in-tank sampling and single-shell tank pumping.

Workers involved in activities for the tank farms that do not potentially expose them to direct contact with the waste shall receive 24 hours of hazardous waste operations training. The work being performed must meet all of the following criteria for the 24-hour training requirement to apply.

- workers will not directly contact tank headspace (no breaking of tank containment),

- workers will not contact tank waste or waste-contaminated materials,

- workers will not be directly involved in the operation or maintenance of installed tank farm equipment. 
This training must be supplemented with a minimum of 1 day of actual field experience under the direct supervision of a trained, experienced supervisor. The program shall include annual 8-hour refresher training.

\section{C3.3.1 Upgrading of Worker Status}

Workers with 24 hours of hazardous waste worker training (tank farm workers) who become hazardous waste workers can upgrade their training by obtaining an additional 16 hours of training and 2 days of actual field experience under the direct supervision of a trained, qualified supervisor.

\section{C3.3.2 Equivalent Training}

Employees who can document or certify that their work experience and/or training has resulted in training equivalent to a 24 - or 40 -hour course written to 29 CFR 1910.120 requirements shall not be required to retake initial training. Responsibility for determination of equivalent training is with the Environmental Training organization. However, certified employees who are new to the Hanford Site shall receive appropriate site-specific training before site entry and shall have appropriate supervised field experience at the site to qualify for unescorted access.

\section{C3.3.3 Refresher Training}

All employees requiring 24- or 40-hour hazardous waste worker training shall receive 8 hours of refresher/retraining anmually. Workers who do not complete the refresher training (such as those not assigned to hazardous waste operations for an extended period) must retake initial training if: (1) they are reassigned to hazardous waste operations and (2) more than 3 years have passed since they completed the initial or refresher training. Refresher training is due by the anniversary date of the initial training. There are no exceptions.

\section{C3.4 ONSITE MANAGEMENT AND SUPERVISORS}

Onsite management and/or supervisors who supervise or are directly responsible for employees engaged in activities at Tank 241-Z-361 must be trained to the same level as the employees they supervise.

\section{C3.5 HEALTH AND SAFETY STAFF}

Industrial safety, industrial hygiene, and fire protection personnel assigned to support this project shall meet the most stringent of health and safety training requirements for the site and PFP facility. This requirement allows field support to be provided under all conditions. 


\section{C3.6 VISITORS, REGULATORS, AND OTHERS}

Visitors, regulators, and others are defined as persons who are only occasionally at the tank farm facilities for the purpose of visual inspection, surveillance, or observation. A visitor may also perform work activities not involving critical systems and installed equipment, operations, or maintenance as long as there will not be contact with tank headspace (no breaking of tank containment), tank waste, or waste-contaminated materials. Examples of such work include an engineer measuring a pipe, a tow-truck driver pulling an inoperable vehicle out of a farm, a subcontractor excavating for placement of forms, etc. Visitors will be escorted per PFP policy and will not be directly engaged in any Tank 241-Z-361 site activities that require entry into a controlled zone or activities that could result in exposure to hazardous substances or other health and safety hazards identified for this work activity. Visitors shall never be permitted to enter a controlled (i.e., exclusion) zone or decontamination zone (i.e., contamination reduction zone and corridor) unless they meet all of the training requirements specified for the area they are to enter. Access is controlled by the ACES as described in Section C8.0. Any exceptions to the entry requirements must be approved by the Shift Operations Manager, the PIC and PFP safety personnel.

\section{C3.7 REGULATORS}

Personnel from regulatory agencies not falling under BWHC oversight responsibilities shall be responsible for compliance with applicable federal, state, and local requirements for entry into the tank farms. When checking in with the ACES station, they will be requested to verify that they have met appropriate training and hazardous waste physical requirements for tank farms entry. Unless regulators have completed Tank Farm Orientation and PFP training and met applicable tank farm supervised field experience requirements, they will require an escort. Any exceptions to the entry requirements must be approved by the Shift Operations Manager.

\section{C3.8 RECORD OF TRAINING}

A record of training shall be kept and entered into the ACES database. If completed training for an individual has not been entered into the ACES, evidence of training (roster, card, etc.) may be presented for review and acceptance by the ACES station operator.

Training conducted as part of the Quality Training and Resource Center program is recorded upon receipt of course completion rosters. FDH Training Records staff enters the data, which includes employee payroll number, course number, course title, date taken, name of instructor, and recertification date (if required). This data is then entered into the Soft Reporting System where the Training Records Information System (employee training) can be accessed. Training information required by the ACES is forwarded electronically for incorporation into the ACES database. 
Personnel completing the 24- or 40-hour worker hazardous waste operations training or 8-hour annual refresher course are issued a card by the International Environmental Institute to reflect completion of OSHA 29 CFR 1910.120 hazardous waste operations training. 


\section{C4.0 PERSONAL PROTECTIVE EQUIPMENT}

The purpose of PPE is to shield or isolate individuals from the chemical, physical, biological, and radiological hazards that may be encountered during field operations. The use of PPE to mitigate a hazard should be chosen only after a determination that engineered safeguards and/or administrative controls do not provide adequate protection. The specific PPE requirements will vary depending on the nature of the work being performed and the area where the task is taking place. Requirements for PPE are itemized or noted in work control documentation, JHA, and/or RWPs, as applicable, and requirements shall be discussed with workers during prejob briefings. The planned activities at Tank 241-Z-361 will follow the PPE procedures established by TWRS. These procedures are described in the following sections.

\section{C4.1 PERSONAL PROTECTIVE EQUIPMENT SELECTION GUIDELINES}

The preliminary evaluation of protective equipment needs for the Tank 241-Z-361 Phase I activities indicates that Level B protection is appropriate (i.e., supplied air respirator and anticontamination clothing). Industrial hygiene personnel and Health Physics must evaluate the hazards identified during work location characterization and analysis. If engineered safeguards and/or administrative controls cannot be used, the Industrial Hygienist and Health Physicist, in concert with the PIC, will select PPE to protect employees from the known and potential hazards likely to be encountered at the Tank 241-Z-361 Site. Health Physics will identify PPE requirements for radiological hazards via the RWP. Where PPE is necessary to address both chemical and radiological concerns, the Industrial Hygienist, PIC, and Health Physics will jointly determine requirements through the work planning and/or as low as reasonably achievable review process.

Employees who are engaged in activities at the site which require the use of PPE must meet all applicable training requirements specified in Project Hanford Occupational Safety and Health Policies and Procedures, and the medical surveillance requirements identified in Section C5.0 of this appendix.

Once a work activity has begun, if the level of PPE for the actual site conditions is found to be inadequate, the job supervisor/PIC will be notified immediately and work will stop until an evaluation is performed and approval to resume work activities is granted.

\section{C4.2 LEVEL D PERSONAL PROTECTIVE EQUIPMENT}

Level D PPE is the minimum basic level of PPE used at the Tank 241-Z-361 Site for areas or operations where no air contaminants are present which would require respiratory protection. However, while enroute from one work location to another, modesty clothing is acceptable as the minimum dress. This also allows workers exiting a radiological surface contamination area to remove protective clothing at the step-off pad and proceed to the change trailer in modesty 
clothes. No work may be performed in modesty clothing. Specific PPE requirements will be determined by hazards associated with the work activity and may include the following:

- coveralls and/or street clothes (covering the legs and shoulders),

- anti-contamination clothing (as required by Health Physics if radiological hazards exist),

- substantial footwear, and

- gloves.

\section{C4.3 LEVEL C PERSONAL PROTECTIVE EQUIPMENT}

Level C PPE is required where conditions are known or characterized, and a potentially hazardous atmosphere exists. Use of Level C PPE is not permitted in oxygen-deficient atmospheres (less than 19.5 percent oxygen), for contaminants with poor warning properties (odor detection level is greater than the threshold limit value [TLV]), or when contaminant concentrations exceed the respirator canister limits. Personnel working inside the Tank 241-Z-361 Site wearing Level C PPE shall wear the following as a minimum:

- full-face air-purifying respirators (APR) (with appropriate filters and prescription eye wear),

- anti-contamination clothing,

- substantial footwear, and

- gloves.

\section{C4.4 LEVEL B PERSONAL PROTECTIVE EQUIPMENT}

Level B PPE is required where conditions are unknown, and a potentially hazardous atmosphere exists. Level B PPE may be used only when it is unlikely that workers will be exposed to high concentrations of contaminants or chemical splashes that will affect the skin or be absorbed by it. Level B is generally the same as Level C, except the respiratory protection is upgraded to air-supplied respirator or SCBA. Personnel working at the Tank 241-Z-361 Site with designated Level B PPE shall wear the following as a minimum:

- pressure demand air-supplied respirator or SCBA,

- anti-contamination clothing (as required by Health Physics if radiological hazards exist),

- substantial footwear, and

- gloves. 


\section{C5.0 MEDICAL SURVEILLANCE}

Medical surveillance requirements for the Tank 241-Z-361 activities are identical to those established for other tank farm operations. These requirements are described in the following sections.

\section{C5.1 MEDICAL EXAMINATIONS}

All employees who require access to the Tank 241-Z-361 Site and may potentially be exposed to hazardous materials at or above the TLV and/or permissible exposure limit (PEL) for 30 or more days per year; or are required to wear a respirator will participate in the medical surveillance program as required by 29 CFR 1910.120 .

The medical surveillance program, which is designed to assess, monitor, and maintain records for worker health and fitness for employment, consists of a pre-employment screening, periodic medical examination, follow-up exposure physicals (as required by the Occupational Health Examiner [OHE]), and a termination examination.

The medical contractor for the Hanford Site provides medical services for BWHC and LMHC. The medical contractor will be provided with information relative to the type of work being performed, potential and actual exposures, and expected contaminants. The provision on information is accomplished through the Employee Job Task Analysis process. This process involves workers, management, and industrial hygiene personnel jointly developing an exposure profile, medical surveiliance needs, and training required for each individual.

\section{C5.2 PERIODIC MEDICAL EXAMINATION}

The periodic medical examination will determine biologic trends that may mark early signs of adverse health effects, and thereby facilitate appropriate protective measures. The frequency of the periodic medical examination will depend on the extent of potential or actual exposures as determined by the OHE and the Employee Job Task Analyses.

The annual examination may consist of the following:

- updated medical history,

- physical examination,

- chemical panel,

- urinalysis,

- complete blood count, 
- pulmonary function test (PFT) (as determined by the Employee Job Task Analyses),

- respirator fit test (as determined by the Employee Job Task Analyses),

- electrocardiogram (EKG) (as determined by the OHE),

- chest $\mathrm{x}$-ray within 54 months (as determined by the OHE),

- visual acuity, and

- hearing conservation audiogram (for individuals exposed to an 8-hour time-weighted average of $85 \mathrm{dBA}$ or greater).

\section{C5.3 FOLLOW-UP EXPOSURE PHYSICAL}

Potential job-related symptoms or illnesses must be reported as soon as possible to the employee's supervisor and the medical contractor. The OHE will perform a follow-up physical to evaluate the symptoms or illness in the context of the employee's exposure to hazardous substances.

Based on the results of the pre-employment or periodic medical examinations, the OHE may determine that follow-up examinations or consultations are medically necessary. It is the responsibility of the employee to participate in the follow-up examinations as directed by the OHE.

Any person who feels he/she has been exposed to noxious vapors or suspects that he/she was exposed to a hazardous material or chemical that exceeded the established PEL and/or TLV shall report the information to their direct supervisor and medical staff at the nearest Health Service Center. The concerned worker will be evaluated by a designated doctor. An entry will be made into the medical surveillance tracking log for continued follow-up, as deemed appropriate by medical and industrial hygiene staff.

\section{C5.4 EMERGENCY MEDICAL SURVEILLANCE}

Employees must notify their supervisor and report to the medical contractor's nearest Health Service Center for an evaluation. The contents of the evaluation will be determined by the OHE based on the circumstances of the incident.

Employees who feel they may have been exposed to noxious vapors, or suspect that they received an over exposure to a hazardous material or chemical (which exceeded the established PEL and/or TLV), shall promptly notify their supervisor and report to first aid. An OHE will evaluate the employee and based on the evaluation, enter the individual into the medical surveillance tracking log for continued follow-up, as appropriate. 


\section{C5.5 RECORD KEEPING}

Employee medical records are maintained by the medical contractor for the duration of employment plus 30 years.

Copies of the medical examinations can be made available to the employee as requested. Employees or their designated representative may request a copy of their medical records by completing the Request for Information form from the medical contractor. For records older than two years, the Privacy Act Information Request (DOE form F1800.1) must be completed. This form can be obtained from the DOE, Richland Operations Office (RL). The medical contractor provides the physician's written opinion (PWO) to the employee and a copy to industrial hygiene. The PWO contains information regarding the employee's fitness for work, including the ability to wear PPE, and the results of the examinations and tests. The PWO is maintained in the employee's medical file.

The medical clearance form is forwarded to the employee and to the employee's manager by the medical contractor. A medical clearance indicates restrictions or provides full clearance for performing the work duties. If an employee is injured or exposed to a toxic material, a medical clearance must be evaluated by the medical contractor and signed before the employee is authorized to return to work.

\section{C5.6 BLOODBORNE PATHOGEN EXPOSURE CONTROL}

It is unlikely that bloodborne pathogens will present a problem for this project. Any potential pathogens will be controlled in accordance with TWRS Administrative Manual, HNF-IP-0842, Vol. IX, Section 1.2, "Bloodborne Pathogen Exposure Control Plan" (WHC 1992). 


\section{C6.0 MONITORING}

\section{C6.1 OVERVIEW}

The purpose of industrial hygiene monitoring during Tank 241-Z-361 activities is to assess employee exposure to chemical and physical agents in the work place. This monitoring effort is essential before instituting control measures, as the degree of control must be based on level of hazard present. Monitoring at Tank 241-Z-361 can be divided into monitoring for assessment purposes and monitoring for entry into the work area. While both types of monitoring are necessary, they serve somewhat different purposes. The primary purpose of assessment monitoring is to identify and quantify specific chemical and physical agents present in the work place as part of an industrial hygiene strategy. Entry monitoring is performed to evaluate agents at the time specific work is being performed. Entry monitoring is thus targeted more toward verifying that existing control measures are adequate, rather than identifying or quantifying contaminant levels.

Monitoring can be broken down into two basic subgroups: chemical and physical agents. Chemical agents include gases and vapors, and any chemical agents used in operations or maintenance activities at the farms. Physical agents include noise, heat, illumination, explosivity, asbestos, ergonomic and biologic factors, and others. Monitoring for both classes of occupational stressors is necessary to fully characterize the associated. Monitoring will be prioritized based on perceived need given the amount of available baseline monitoring data and a JHA.

\section{C6.2 WORK ACTIVITY MONITORING}

A JHA of planned work activities shall be performed and reviewed by the industrial hygienist and the industrial safety professional. This review is to ensure that all hazards that might affect employee health have been considered before worker entry into the work area. This includes existing hazards present before entry, chemicals introduced during work activities, and any expected reaction products.

The JHA consists of an evaluation for any potential exposure to physical hazards and chemical contaminants based on where the work is to be performed and what operations are to be conducted. This monitoring plan was developed to ensure that employee exposures to chemical and physical hazards are evaluated, and that appropriate controls are instituted to protect worker health and safety. There are three types of monitoring being used to assess exposure levels. Each of these is discussed in Sections C6.2.1 through C6.2.3. 


\section{C6.2.1 Personal Monitoring}

Personal monitoring consists of attaching various sampling devices to an employee during their work tasks and evaluating any determinant exposures. Personal exposure monitoring is considered to be the closest measure of employee exposure.

\section{C6.2.2 Area Monitoring}

Area monitoring involves the collection and analysis of samples in the general area where work is taking place. Area monitoring provides a general overview of the potential for employee exposure and is considered more representative than source monitoring (Section C6.2.3). Area monitoring can include both entry and assessment monitoring, if entry monitoring has been defined as a control measure for the specific agent.

\section{C6.2.3 Source Monitoring}

Source monitoring consists of the collection of samples at the supposed source. This type of monitoring is used to determine the highest potential for which employees could be exposed. Source monitoring is also useful in providing an estimate of the frequency and magnitude of any release.

\section{C6.3 SAMPLING AND MONITORING EQUIPMENT}

The DynCorp Industrial Hygiene Instrument Laboratory currently maintains monitoring equipment. Tables C6-1 and C6-2 describe the types of monitoring equipment available to assist in the characterization of employee exposures at Tank 241-Z-361 for both chemical and physical agents.

\section{C6.4 SAMPLING COLLECTION AND ANALYSIS}

Industrial hygienists are responsible for sample collection and analysis. Sampling and analytical methods will adhere to standard operating procedures for industrial hygiene monitoring and evaluation.

\section{C6.5 MONITORING DATA REVIEW AND ACTION}

Monitoring data will be reviewed by an industrial hygienist and compared to established safe levels. Safe levels for gas or vapor exposure have been established in the form of an administrative action level by TWRS Safety. This action level is known as an occupational exposure limit which has been defined as one-half of the lower of the PEL, the TLV, or the NIOSH recommended exposure limit. Engineering controls will be implemented or PPE issued 
if monitoring data suggests that workers could be exposed at a level exceeding the occupational exposure limit. Data review/action for dermal exposure to chemical agents and exposure to physical agents in the tank farms will be completed using OSHA standards and American Conference of Government Industrial Hygienists (ACGIH) guidelines.

Table C6-1. Chemical Agents-Monitoring Tool.

\begin{tabular}{|l|c|l|}
\hline \multicolumn{1}{|c|}{ Tool } & Need & \multicolumn{1}{c|}{ Main feature(s) } \\
\hline $\begin{array}{l}\text { Combustible gas } \\
\text { indicator }\end{array}$ & $\begin{array}{c}\text { Flammable } \\
\text { gases }\end{array}$ & $\begin{array}{l}\text { Nonspecific detector for combustible gases measures gas } \\
\text { concentrations as a percentage of lower explosive limit; visual and } \\
\text { audible alarms. }\end{array}$ \\
\hline Oxygen meter & $\begin{array}{c}\text { Oxygen } \\
\text { deficiency }\end{array}$ & Direct readout in percent oxygen; visual and audible alarms. \\
\hline $\begin{array}{l}\text { Organic vapor } \\
\text { meters/analyzers }\end{array}$ & Toxic gas/vapor & $\begin{array}{l}\text { Nonspecific gas and vapor detection for organics and some } \\
\text { inorganics; sensitivity related to ionization potential. }\end{array}$ \\
\hline Indicator tubes & Toxic gas/vapor & Quantitative accuracies are variable; real time/semireal time results. \\
\hline Multi-gas meter & Toxic gas/vapor & $\begin{array}{l}\text { Generally compound specific; audible alarm upon exceeding preset } \\
\text { action level. }\end{array}$ \\
\hline $\begin{array}{l}\text { Sampling media, } \\
\text { containers, and pumps }\end{array}$ & $\begin{array}{c}\text { Specific } \\
\text { contaminants }\end{array}$ & $\begin{array}{l}\text { Collects personal sample in the "breathing zone" to evaluate the } \\
\text { exposure level of the person sampled; requires laboratory analysis; } \\
\text { most accurate method for measuring exposure. }\end{array}$ \\
\hline
\end{tabular}

Table C6-2. Physical Agents-Monitoring Tool.

\begin{tabular}{|c|c|c|}
\hline Tool & Need & Main feature(s) \\
\hline Sound level meter & $\begin{array}{c}\text { Sound levels from } \\
\text { noise source }\end{array}$ & $\begin{array}{l}\text { Provides real time measurements of sound levels; has mechanism that } \\
\text { duplicates the sensitivity of the human ear. }\end{array}$ \\
\hline Noise dosimeter & Exposure to noise & $\begin{array}{l}\text { Worn by the person being sampled to record the noise energy to which the } \\
\text { worker was exposed throughout the work shift. }\end{array}$ \\
\hline Octave band analyzer & $\begin{array}{c}\text { Quieting a noise } \\
\text { source }\end{array}$ & $\begin{array}{l}\text { Identifies sound intensities at various frequencies to establish engineering } \\
\text { controls. }\end{array}$ \\
\hline $\begin{array}{l}\text { Wet bulb globe } \\
\text { thermometer }\end{array}$ & Heat stress & $\begin{array}{l}\text { Provides an environmental measurement of heat stress to workers by } \\
\text { measuring air temperature and movement, water vapor pressure, and radiant } \\
\text { heat. }\end{array}$ \\
\hline Light meter & $\begin{array}{l}\text { Illumination } \\
\text { levels for specific } \\
\text { tasks }\end{array}$ & $\begin{array}{l}\text { Measures visible radiation falling on a surface, or the brightness of reflective } \\
\text { light. }\end{array}$ \\
\hline Observation & $\begin{array}{l}\text { Evaluate work } \\
\text { practices and } \\
\text { conditions }\end{array}$ & $\begin{array}{l}\text { Practical, effective method of appraising work practices, determining work } \\
\text { station layout, verifying structural and wiring configurations, identifying } \\
\text { signs of physiological and psychological stress in workers, and ensuring } \\
\text { compliance with procedures. }\end{array}$ \\
\hline
\end{tabular}




\section{C6.6 DETERMINING FACTORS FOR MONITORING AND RESPIRATORY PROTECTION REQUIREMENTS}

Monitoring strategies and respiratory protection prescriptions are based on the expected or measured hazard that is affected by both the work location and the type of work being performed. A job may require respiratory protection because the location has the potential to contain a respiratory hazard. Similarly, a job may require monitoring because of the kind of work being performed, even though no monitoring is required for the specific location. Only by considering both the location of the work and the type of work being performed can the proper levels of respiratory protection and monitoring be determined.

In order to reduce potential for exposures at Tank 241-Z-361, the minimum contingent of employees necessary to perform the work scope should be used. Employees not needed to support the immediate work activity should stand well clear of the exclusion zone in the upwind direction, if possible. Any necessary monitoring shall be performed by an Industrial Hygienist or an Industrial Hygienist Safety Technician under the direction of an industrial hygienist before starting work activities.

\section{C6.6.1 Monitoring Methods and Respiratory Protection}

Monitoring for toxic gases and flammable gases shall be conducted throughout the activity at Tank 241-Z-361. Flammable gases shall be conducted as detailed in the JCO (PHMC 1998a). Toxic gases shall be monitored in accordance with this section. Respiratory protection, when required, generally involves the use of supplied air or a full-face APR with GME-H or GME-P100 cartridges, depending on location or activity.

During the breach of containment, supplied air shall be worn and initial monitoring for toxic gases shall be performed at the designated source port. If this measurement indicates concentrations greater than the allowable source concentrations identified in Table C6-3, breathing zone monitoring is required for personnel working directly outside the riser. If breathing zone concentrations are greater than Table C6-3 limits, appropriate actions shall be taken in accordance with Table C6-3. The monitoring requirements are summarized in Table C6-4.

\section{C6.6.2 Monitoring Methods and Compounds of Concern}

Air monitoring shall be performed for the compounds of concern as discussed in Sections C2.3, $\mathrm{C} 2.4$, and Attachment $\mathrm{C}-1$ of this appendix, in the following order: (1) flammable gas, (2) organic vapors, (3) ammonia, (4) carbon tetrachloride, and (5) other monitoring as identified by the Industrial Hygienist. After the initial breach of containment, monitoring for ammonia and carbon tetrachloride will only be required if the source monitoring action levels in Table C6-3 are exceeded. 
Table C6-3. Action Levels for Industrial Hygiene Monitoring Readings. ${ }^{1}$

\begin{tabular}{|c|c|c|c|}
\hline \multirow[b]{2}{*}{ Contaminant } & \multicolumn{3}{|c|}{ Action } \\
\hline & $\begin{array}{l}\text { Monitor breathing zone } \\
\text { if source indicates } \\
\text { levels are exceeded }\end{array}$ & $\begin{array}{l}\text { Full-face mask APR with } \\
\text { GME-H/GME-P100 } \\
\text { cartridge required if the } \\
\text { following organic vapor or } \\
\text { ammonia breathing zone } \\
\text { levels are exceeded; supplied } \\
\text { air required if the following } \\
\text { carbon tetrachloride } \\
\text { breathing zone levels are } \\
\text { exceeded }\end{array}$ & $\begin{array}{l}\text { Stop work and } \\
\text { evacuate area if any } \\
\text { of the following } \\
\text { breathing zone levels } \\
\text { are exceeded }\end{array}$ \\
\hline $\begin{array}{l}\text { Organic vapors } \\
\text { (3-minute reading) }\end{array}$ & $2 \mathrm{ppm}$ & $2 \mathrm{ppm}$ & $25 \mathrm{ppm}$ \\
\hline Ammonia & $12 \mathrm{ppm}$ & $12 \mathrm{ppm}$ & $250 \mathrm{ppm}$ \\
\hline Carbon tetrachloride & $1 \mathrm{ppm}$ & $2 \mathrm{ppm}$ & $25 \mathrm{ppm}$ \\
\hline
\end{tabular}

${ }^{\mathrm{T}}$ Radiological conditions may warrant additional controls. Consult with the Radiological Control Analyst.

APR - air-purifying respirator.

Table C6-4. Summary of Toxic Vapor Monitoring Requirements.

\begin{tabular}{|l|l|}
\hline \multicolumn{1}{|c|}{ Activity/Condition } & \multicolumn{1}{c|}{ Tank 241-Z-361 } \\
\hline Initial Containment Breech & $\begin{array}{l}\text { personnel wear supplied air, } \\
\text { toxic monitoring at designated source port, and } \\
\end{array}$ \\
\hline Tank Intrusive Activities & $\begin{array}{l}\text { toxic gas monitoring at designated source port and } \\
\text { take actions described in Table C6-3. }\end{array}$ \\
\hline
\end{tabular}

Flammable gases are measured to determine their percent of LFL and oxygen content using a Model 251 Industrial Scientific Combustible Gas Meter, or TMX-410 multi-gas monitor, or equivalent. The JCO contains current flammable gas monitoring requirements.

Organic vapor concentrations in the work area are measured qualitatively using an organic vapor meter (OVM) with an $11.7 \mathrm{eV}$ lamp or the equivalent. Ammonia and carbon tetrachloride levels are determined using colorimetric indicator tubes or equivalent. Action levels for OVM, ammonia, and carbon tetrachloride readings are described in Table C6-3. This type of monitoring is to be performed only by an Industrial Hygienist or Industrial Hygienist Safety Technician under the direction of an Industrial Hygienist.

Ammonia and organic levels are measured inside the respiratory protection zones for the tanks indicated in Table C6-4. Initial readings taken at the riser or in the vapor space that exceed exposure standards shall require an Industrial Hygienist or Industrial Hygienist Safety Technician to monitor the breathing zone for the respiratory protection setting. If the values exceed the limits specified in Table C6-3, either respiratory protection will be worn or the work will be discontinued as shown in the table. 
In the event that exceeded breathing zone concentrations of ammonia or carbon tetrachloride result in stopping work and evacuation the farm, operations will not resume until approval is received from the Operations Manager and a TWRS Safety industrial hygienist.

\section{C6.6.3 Personal Sampling}

Personal sampling shall be conducted on representative employees throughout the Tank 241-Z-361 work activities. Sampling shall be conducted for the compounds of concern in accordance with established industrial hygiene protocols and under the direct supervision of an industrial hygienist.

\section{C6.7 INCIDENT RECOVERY}

In the event of a tank incident and resulting evacuation, re-entry to work area shall be coordinated by operations management and conducted by Industrial Hygiene and Health Physics personnel. Tank incidents include, but are not limited to, gas release events, tank pressurization, high-LFL, and immediately dangerous to life and health breathing zone concentrations. SCBAs should be used for recovery when the immediately dangerous life and health may be exceeded. 


\section{C7.0 DECONTAMINATION PROCEDURES}

All personnel, protective equipment, and tools that may have been contaminated with chemical or radiological contaminants will be decontaminated prior to leaving the site. The field operations manager will supervise the establishment of a contamination reduction zone of sufficient size and equipped with sufficient supplies to support decontamination of personnel and equipment before leaving the exclusion zone. The general decontamination requirements established for work at Tank 241-Z-361 are described in the following sections.

Normal tank farm operations deal mainly with radiological decontamination. When unusual work is performed at the tank farms and a step-by-step decontamination protocol for site personnel and equipment is required, this protocol can be found in the specific work plan, procedure, or package.

Decontamination, the process of removing or neutralizing contaminants that have accumulated on personnel and equipment, is critical to worker health and safety. Decontamination protects workers from contact with hazardous substances that may contaminate and eventually permeate protective clothing, respiratory equipment, tools, vehicles, and other equipment used on site. Decontamination: (1) protects all site personnel by minimizing the transfer of harmful materials into clean areas, (2) helps prevent mixing of incompatible chemicals, and (3) protects the community by preventing uncontrolled transportation of contaminants from the site.

Decontamination takes on additional significance in that most chemical contamination will be combined with radiological contamination, thus making the decontamination problem one of dealing with mixed wastes. If equipment or personnel are radiologically contaminated, decontamination procedures shall comply with guidelines established in the Hanford Site Radiological Control Manual (HSRCM-1) (DOE-RL 1994). If radiological contamination is detected on skin or clothing by any means, a HPT must be contacted. Contaminated personnel shall be decontaminated following site procedures. Easily detected radiological contamination serves as an indicator of potential chemical contamination when working with mixed wastes, similar to the use of radioactive tracers.

\section{C7.1 PREVENTING CONTAMINATION}

\section{C7.1.1 Minimizing Contamination}

The amount of decontamination required can be minimized substantially by adhering to the following operating guidelines and requirements.

1. Observe work practices that minimize contact with hazardous substances (e.g., do not walk through areas of known contamination; do not directly touch potentially hazardous substances). 
2. Protect monitoring and sampling instruments by bagging the instrument bodies and probes and wrapping cords in appropriate material (such as cellophane or plastic). Make openings in the bags for sample ports and sensors that must contact site materials.

3. Wear disposable outer garments and use disposable equipment where appropriate.

4. Cover equipment and tools with a strippable coating that can be removed during decontamination.

5. Encase the source of contaminants (e.g., with plastic sheeting or overpacks).

\section{C7.1.2 Proper Dressing Procedures}

Adherence to proper procedures for dressing before entering a radiation area minimizes the potential for contaminants to bypass the protective clothing and escape decontamination. In general, all fasteners should be used (i.e., velcro fully closed, all buttons used, all snaps closed). Gloves and boots should be tucked under the sleeves and legs of outer clothing, and hoods (if not attached) should be worn outside the collar. Another pair of tough outer gloves is often worn over the sleeves. All open joints should be taped to prevent contaminants from running inside the gloves, boots, and jackets (or suits, if one-piece construction). Specific requirements shall be addressed by the applicable RWP and/or JHA.

\section{C7.1.3 Personal Protective Equipment Checks}

PPE shall be checked before each use to ensure that it contains no cuts or punctures that could expose workers to contaminants. Injuries to the skin (such as cuts and scratches) may enhance the potential for chemicals, radioactive contaminants, or infectious agents that directly contact the worker's skin and penetrate into the body. Workers with open cuts or damaged skin should be kept from working until the skin heals or the area is protected with an approved covering.

\section{C7.1.4 Surveying of Instruments}

All instruments and equipment must be surveyed by an HPT for radiological contamination control purposes before being removed from a contamination area. Items with detectable levels of contamination must be controlled as radioactive material (controlled or regulated equipment).

\section{C7.2 TYPES OF CONTAMINATION}

Personnel and equipment contamination at hazardous waste sites such as Tank 241-Z-361 can take numerous forms (e.g., solids, liquids, and gases). These contamination forms can require unique approaches to decontamination. These approaches are discussed in the following sections. 


\section{C7.2.1 Physical States of Contaminants}

Contaminants may be present in the form of solids, liquids, gases, or vapors. Dust and dirt contaminated with radionuclides, toxic organic compounds, or metals may collect on the surface of PPE, or in cracks, crevices, folds, and seams. Specific contaminants (when known) will be addressed as part of the site-specific characterization and analysis. Specific task-related concerns should be addressed in the RWP and/or JHA.

\section{C7.2.2 Liquids and Gases}

Liquid and gaseous contaminants may be limited to the surface of PPE or may permeate the PPE material. Surface contaminants may be easy to detect and remove; however, contaminants that have permeated a material are difficult or impossible to detect and remove. If contaminants that have permeated a material are not removed by decontamination, they may continue through the material until they reach the inner surface, where they can cause an unexpected exposure (breakthrough). This is one advantage of the use of disposable protective clothing (provided that the clothing is changed at intervals that are less than the chemical breakthrough time).

\section{C7.2.3 Breakthrough Time}

Five major factors that affect the breakthrough time:

1. Contact Time-The longer a contaminant is in contact with an object, the greater the probability and extent of permeation. For this reason, minimizing contact time is one of the most important objectives of a decontamination program.

2. Concentration-Molecules tend to flow from areas of high concentration to areas of low concentration. As concentrations of wastes increase, the potential for permeation of personal protective clothing also increases.

3. Temperature-An increase in temperature generally increases the permeation rate of contaminants.

4. Size of Contaminant Molecules and Pore Space-Permeation increases as the contaminant molecules becomes smaller and as the pore space of the material to be permeated increases.

5. Physical State of Wastes-As a rule, gases, vapors, and low-viscosity liquids tend to permeate more readily than high-viscosity liquids or solids. 


\section{C7.3 POLICIES FOR DECONTAMINATION PROCEDURES}

General Guidance:

1. Decontamination procedures shall be developed, communicated to employees, and implemented before any employees or equipment may enter onsite areas where potential for exposure to hazardous substances exists. Decontamination procedures shall be incorporated as part of the RWP.

2. A step-off pad shall be established between the radiation area and the radiation buffer area for each task. Disposable clothing is to be removed (outer layers are removed first) and placed in containers. Nondisposable clothing (such as anti-contamination clothing) that can be cleaned will be removed, bagged, and sent to the laundry. After removing outer protective clothing, each team member must be surveyed before being permitted to go into an uncontrolled area.

3. If radioactive skin or clothing contamination is detected, decontamination must be performed under the direction of the HPT.

4. The RWP should be revised whenever the type of personal protective clothing or equipment changes, the site conditions change, or the site hazards are reassessed based on new information.

\section{C7.4 POLICIES FOR SPECIFIC DECONTAMINATION PROCEDURES}

\section{C7.4.1 Objectives}

The primary objective of decontamination procedures is to minimize the risk of personnel exposure to hazardous substances. Historically, decontamination of personnel has involved a successive removal sequence, from outermost to innermost layers of protective clothing. However, in many instances, the objectives of decontamination can be accomplished most effectively by the use of disposable protective clothing, combined with the systematic removal and disposal of multiple layers of protective coveralls, gloves, and boot covers.

\section{C7.4.2 Decontamination Required}

All personal, nondisposable clothing, equipment, and samples leaving the contaminated area must be decontaminated or properly packaged to prevent the spread of any harmful chemicals, or radioactive contamination that may have adhered to them. 


\section{C7.4.3 Health and Safety of Decontamination}

Normal radiation decontamination procedures provide adequate decontamination for known chemical agents that are evaluated for health and safety aspects.

\section{C7.4.4 Change Rooms}

Anti-contamination clothing will be provided at the Tank 241-Z361 work site by PFP. At special access points (step-off pads), change areas are frequently set up for special tasks. Personnel who have reason to don anti-contamination clothing in areas other than the change rooms shall contact Health Physics before obtaining or transporting the anti-contamination clothing. Most of the authorized change rooms are trailers that are used as exit and entry points to controlled areas. Change facilities for work at Tank $241-\mathrm{Z}-361$ will be located in a TWRS job trailer placed in the 241-Z-361 support area.

\section{C7.4.5 Showers}

Although there are various showers that could be used in an emergency for decontamination, the only authorized fixed shower is located at the PFP. The shower at Building $2704 \mathrm{HV}$ will be used by project personnel for non-emergency showering.

\section{C7.5 TESTING FOR DECONTAMINATION EFFECTIVENESS}

\section{C7.5.1 Visual Observation}

In some cases, the effectiveness of decontamination can be estimated by visual observation. Discolorations, stains, corrosive effects, visible dirt, or alterations in clothing fabric may indicate that contaminants have not been removed. It is important to remember that not all contaminants leave visible traces. Many contaminants can permeate clothing and are not easily observed.

\section{C7.5.2 Wipe-Testing/Direct Reading Sampling}

Wipe-testing/direct reading sampling provides after-the-fact information on the effectiveness of decontamination. For this procedure, a dry or wet cloth, glass fiber filter paper, or swab is wiped over the surface of the potentially contaminated object and then analyzed in a laboratory. For direct reading, a personal air monitor (PAM)/poppy and Geiger-Mueller counter may be used for a whole body survey. Both the inner and outer surfaces of protective clothing should be tested. 


\section{C7.5.3 Testing for Permeation}

Testing for the presence of permeated contaminants requires that pieces of the protective garment(s) be sent to a laboratory for analysis.

\section{C7.6 HEALTH AND SAFETY HAZARDS}

While decontamination is performed to protect health and safety, it can pose hazards under certain circumstances. Decontamination methods may:

- be incompatible with the hazardous substances being removed,

- be incompatible with the clothing or equipment being decontaminated, and

- pose a direct health hazard to workers.

The chemical and physical compatibility of the decontamination solutions or other decontamination materials must be determined before they are used. A qualified health professional should assess the benefits and risks associated with the use of decontamination methods at a waste site.

\section{C7.7 DECONTAMINATION EQUIPMENT} SELECTION

In selecting decontamination equipment, it is important to consider whether the equipment itself can be decontaminated for reuse or disposed of easily.

\section{C7.8 DISPOSAL METHODS}

All decontamination equipment must be properly decontaminated and/or disposed of (as necessary). All spent solutions and wash water should be collected and disposed of properly. Incompletely decontaminated clothing should be placed in plastic bags or radiation boxes, pending further decontamination and/or disposal. The Generator Services Group provides technical support for designating and disposing of hazardous wastes.

\section{C7.9 PERSONAL PROTECTION}

\section{C7.9.1 General Safe Work Practices}

1. Eating, drinking, smoking, taking medications, and chewing gum are normally prohibited within the radiation area. Under potential heat stress conditions drinking water will be allowed under high-heat conditions. 
2. Do not handle soil, waste samples, or any other potentially contaminated items unless wearing protective gloves as specified in the JHA and RWP.

3. Be alert to potentially changing exposure conditions evidenced by perceptible odors, unusual appearance of excavated soils, or oily sheen on water. Whenever possible, approach from or stand upwind (as indicated by the required onsite windsock) of excavations, boreholes, well casings, and drilling spoils.

4. At the end of the work day, or each job, disposable clothing shall be removed and placed in drums (chemical contamination) or plastic lined radioactive waste containers, as appropriate. Clothing that can be cleaned shall be sent to the Hanford Site laundry contractor.

5. Thoroughly wash hands and face before eating (or putting anything in the mouth) to avoid hand-to-mouth contamination.

\section{C7.9.2 Protection of Decontamination Personnel}

1. All decontamination workers who are in a contaminated area must be decontaminated before entering the clean support zone. The extent of their decontamination should be determined by the types of contaminants they may have contacted and the type of work they performed.

2. Decontamination workers who come in contact with personnel and equipment at the first decontamination station require more protection from contaminants than decontamination workers who are assigned to the last station in the decontamination line.

3. The level of protection required will vary with the decontamination equipment used. Appropriate equipment and clothing for protecting decontamination personnel should be addressed by TWRS Safety, the RWP, or by an HPT.

\section{C7.10 EMERGENCY DECONTAMINATION}

In an emergency, the primary concern is to prevent the loss of life or severe injury to personnel. Personnel must contact the onsite emergency response organizations by calling 911 (by site telephone), Station 1 (by radio), or 811 (by cellular telephone). If immediate medical treatment is required to save a life, decontamination should be delayed until the victim's condition is stabilized. Kadlec Medical Center in Richland has an emergency room and procedures for handling contaminated personnel. If decontamination can be performed without interfering with essential life-saving techniques or first aid, or if a worker has been contaminated with an extremely toxic or corrosive material that could itself cause severe injury or loss of life, decontamination must be performed immediately. If an emergency due to a heart-related illness develops, protective clothing should be removed from the victim as soon as possible to reduce 
the heat stress. During an emergency, provisions must also be made for protecting medical personnel and disposing of contaminated clothing and equipment.

If possible, first responders should: (1) move the person into the radiological buffer area (area of less contamination) and remove the person's outermost layer of protective clothing, (2) place the person on a clean blanket or plastic sheet, and (3) remove their own outermost layer of protective clothing. Ideally, the person's next layer of protective clothing should be removed by rescue personnel who enter the radiological buffer area (area of less contamination) for appropriate life saving/emergency procedures. 


\section{C8.0 SITE CONTROL}

The purpose of site control is to minimize the potential contamination of workers, protect the public from hazards and prevent unauthorized entry. Appropriate site control protocols will be implemented at Tank 241-Z-361. Work area boundary controls are established to limit access to areas of hazard concerns. Based on the expected levels of contamination and work activity, appropriate areas must be established and entry controlled. Unnecessary personnel shall be excluded. Applicable maps reflecting boundary controls shall be posted at the entry points (change trailers) to the work site. The protocols described in this section were developed for use at Hanford tank farms. The requirements for site control at Tank 241-Z-361 are similar to the general tank farm requirements and application of the tank farm protocols is appropriate.

In addition to general training received concerning PPE, all employees entering the designated area around Tank 241-Z-361 shall receive training on the establishment of respiratory protection zones.

Because many tasks at the Tank 241-Z-361 involve radiological work, Contamination/Airborne Radioactivity Control Areas and/or Radiation Areas are established in accordance with HSRCM-1 (DOE-RL 1994).

\section{C8.1 RADIOLOGICAL CONTROL AREAS}

The Tank 241-Z-361 area will be surveyed before the planned vapor sampling action and a preliminary evaluation made of the need for radiological control area establishment. Radiation areas are classified as follows:

- Radiological Buffer Area-An intermediate area established to prevent the spread of radioactive contamination and to protect personnel from radiation exposure.

- Radiation Area-Any area, accessible to individuals, in which radiation levels could result in an individual receiving a deep dose equivalent in excess of $0.005 \mathrm{rem}(0.05 \mathrm{mSv})$ in one hour at $30 \mathrm{~cm}$ from the radiation source or from any surface that the radiation penetrates. (Not anticipated.)

- High Radiation Area-Any area, accessible to individuals, in which radiation levels could result in an individual receiving a deep dose equivalent in excess of $0.1 \mathrm{rem}(0.001 \mathrm{~Sv})$ in one hour at $30 \mathrm{~cm}$ from the radiation source or from any surface that the radiation penetrates. (Not anticipated.) 


\section{C8.2 CONTAMINATION/AIRBORNE RADIOACTIVITY CONTROL AREAS}

- Very High Radiation Area-Any area, accessible to individuals, in which radiation levels could result in an individual receiving an absorbed dose in excess of 500 rads (5 grays) in one hour at $1 \mathrm{~m}$ from the radiation source or from any surface that the radiation penetrates. (Not expected.)

- Contamination Area-Any area where contamination levels are greater than the values specified in HSRCM-1, Chapter 2, Table 2-2 (DOE-RL 1994), but less than or equal to 100 times those values.

- High Contamination Area-Any area where contamination levels are greater than 100 times the values specified in the HSRCM-1, Chapter 2, Table 2-2 (DOE-RL 1994). (Not likely.)

- Fixed Contamination Area-An area with no detectable removable contamination but contains fixed contamination levels exceeding specified limits.

- Soil Contamination Area-An area where surface or subsurface contamination levels exceed specified limits. A Soil Contamination Area may be located outside an Radiological Controlled Area.

- Airborne Radioactivity Area-Any area where the concentration of airborne radioactivity, above natural background, exceeds or is likely to exceed 10 percent of the derived air concentration values. Derived air concentration values are contained in 10 CFR 835, "Department of Energy Occupational Radiation Protection" and Appendix A of this SAP.

\section{C8.3 HAZARDOUS WASTE OPERATIONS/ CLEANUP WORK ZONES}

The procedures addressed in this section are only required for those tasks which fall under nonroutine work requiring a JHA. The planned activities at Tank 241-Z-361 fit under this category of activities. To reduce the accidental spread of hazardous substances from contaminated areas to clean areas, various zones shall be established. By defining work zones, work activities and contamination can be confined to the appropriate areas and personnel can be located and evacuated in an emergency. Hazardous waste operations and waste cleanup projects can be divided into as many different work zones as needed to meet operational and safety objectives. These zones will be specified in the work package. The three primary zones that will be established are the exclusion zone, contamination reduction zone, and support zone.

NOTE: Such work zones shall not be confused with established radiation contamination control zones. 


\section{C8.3.1 Exclusion Zone}

The preliminary exclusion zone around Tank 241-Z-361 will be established at a radius of $20 \mathrm{ft}$ from the tank riser to be opened. The exclusion zone is the area where contamination does exist or could occur.

The outer boundary of the exclusion zone shall be clearly marked by rope, barrier tape, fences, or other physical barriers which include placards or signs. An access control point should be established at the periphery of the exclusion zone to regulate the flow of personnel and equipment into and out of the area. Personnel working in the exclusion zone may include the supervisor/PIC, operators, other workers, and specialized personnel such as equipment operators. All personnel working in the exclusion zone must wear the level of personal protection clothing specified.

\section{C8.3.2 Contamination Reduction Zone}

The contamination reduction zone is a transition area between a contaminated area and the clean area. This zone is designed to reduce the probability that the clean support zone will become contaminated or be affected by hazardous substances from the exclusion zone. Decontamination should take place within a designated area of the contamination reduction zone with the access point located in close proximity to the access point for the exclusion zone. The degree of contamination should decrease as one moves away from the exclusion zone towards the support zone. Personnel protective clothing, equal to but not greater than, that required in the exclusion zone, should be worn by everyone in the contamination reduction zone. Besides decontamination, the contamination reduction zone should be used to facilitate emergency equipment, equipment resupply, sample packaging, worker temporary rest areas, and drainage or containment of water or other liquids used for decontamination.

\section{C8.3.3 Support Zone}

The support zone is the location of the administration support functions needed to keep the other two zones operational and running smoothly. This can be used as a staging area for equipment, containers, and supplies. No special protective clothing is required in this area. Personnel exiting the contamination reduction zone should be monitored before entering the support zone to ensure they are free of all contaminates from the exclusion zone.

\section{C8.4 ACCESS CONTROL}

Access control to areas containing radiological hazards is performed through the ACES. The ACES is used to verify entry requirements are met for individuals requiring access to radiologically-controlled areas. HNF-IP-0842 (WHC 1992), contains access control requirements. 


\section{C8.5 BUDDY SYSTEM}

The purpose of the buddy system is to:

- provide personnel with assistance, if needed;

- observe co-worker for signs of chemical or heat exposure;

- periodically check the integrity of a co-worker's PPE; and

- notify the supervisor if help is needed.

Under the buddy system, an attendant (provided with the required PPE) must be capable of observing the worker performing the task. For Tank $241-Z-361$, the buddy system is used in the following cases:

- activities requiring the use of supplied air or SCBA and

- work performed under a JHA.

Enforcement of the buddy system is the responsibility of the supervisor/PIC.

\section{C8.6 COMMUNICATIONS}

Communications are essential to all smoothly run operations. Personnel should be provided with the appropriate equipment to facilitate the transmission of information necessary to support work activities, report emergencies, and receive emergency information. This does not require that each person be in possession of a transmitting or receiving device, but that such instruments be accessible to workers within the assigned work area. Information can be received by one person and given to other individuals by any recognized direct means. The primary means for communicating to and from the field is by use of radios and cellular phones. 


\section{C9.0 EMERGENCY RESPONSE PLAN}

The activities at Tank 241-Z-361 will utilize HNF-IP-0263-PFP, Building Emergency Plan for Plutonium Finishing Plant Complex (WHC 1998). All TWRS field staff working on the Tank 241-Z-361 project will attend a PFP emergency response briefing. 


\section{C10.0 CONFINED SPACE ENTRY POLICIES, GUIDELINES, AND REQUIREMENTS}

No confined space entry is planned for the Phase I activities at Tank 241-Z-361. If confined space work is determined to be necessary during the course of the work, it will be conducted in accordance with the requirements and procedures prescribed in HNF-PRO-110, "Confined Space" (PMHC 1997f). 


\section{C11.0 ENVIRONMENTAL PROTECTION AND RESPONSE}

Because of the hazardous nature of many materials used and found in the Hanford Site tanks, only trained personnel shall respond to a hazardous material or hazardous waste spill.

Appropriate Material Safety Data Sheets (MSDS) shall be referenced before performing cleanup. All spill responses will be conducted in accordance with the PFP Building Emergency Response Plan (see Section C9.0 of this appendix).

It is the responsibility of the employee identifying the spill to notify the BWHC PFP Building Emergency Director (BED) immediately in the event of a release to the environment, or if unexpected contaminated spills are encountered. The PFP BED, after consulting with the appropriate BWHC environmental group, will determine whether the spill is a reportable occurrence under DOE Order 5000.3B, Occurrence Reporting and Processing of Operations Information (DOE 1990). The requirements for notifying state or other regulatory agencies are included in the BWHC reporting procedures. Substantial spills of hazardous materials may require response by the Hanford Fire Department Hazardous Materials (HAZMAT) Response Team.

\section{C11.1 SMALL CONTROLLED SPILLS}

When the spill is a small, controlled amount and the identity of the spilled substance is known, the spill can be cleaned up by personnel who have received appropriate training. To clean-up a spill, the following actions and MSDS guidelines for the substance should be followed.

- stop the spill,

- warn other people of the spill,

- isolate the area around the spill, and

- minimize personal exposure.

\section{C11.2 LARGE CONTROLLED/UNCONTROLLED SPILLS}

When the spill is large, the Hanford Fire Department HAZMAT Response Team should be notified to clean-up the spill. The HAZMAT Response Team will develop a plan of action on each response (based on training), because every response to a spill is different. 


\section{C12.0 HAZARD COMMUNICATION}

Hazard communication related to the Tank 241-Z-361 sampling and analysis activities will be implemented in a manner consistent and in accordance with PFP hazard communication requirements. The purpose of this program is to communicate to workers the potential for illnesses and injuries related to the work environment. This program requires managers to inform their workers of the hazards in the work area and how they can protect themselves. The written program will be kept in various locations and will be available to all employees.

\section{C12.1 HAZARDOUS CHEMICAL INVENTORY}

A complete, current, hazardous chemical inventory will be maintained for the work conducted at Tank 241-Z-361. The location of "Right-to-know" stations will be identified to project staff during PFP orientation. The chemical inventory must include the MSDS number, may be cross-referenced by synonyms, and may include the Hanford HAZMAT Rating.

\section{C12.2 PHYSICAL AND BIOLOGICAL HAZARD INVENTORY}

A physical and biological hazard inventory will be included consistent with PFP hazard communication requirements. The physical agents considered include fire, lighting, noise, temperature-extremes, and ergonomic hazards. Biological hazards include venomous animals and pathogenic materials. Locations of the physical and biological hazard inventory will be in the "right-to-know" stations as indicated in Section C12.1.

\section{C12.3 CHEMICAL LABELING}

All hazardous materials will be labeled with manufacturers warning labels or with internally generated hazardous materials information system labels.

\section{C12.4 MATERIAL SAFETY DATA SHEETS}

MSDS will be readily available to all employees. They will be retained at the "right-to-know" stations along with the chemical inventories.

\section{C12.5 HAZARDS TRAINING}

All employees will be trained to recognize and protect themselves from all hazards identified upon job assignment. All affected employees will be trained whenever a new hazard is introduced into their work areas. 


\section{C13.0 REFERENCES}

10 CFR 835, "Department of Energy Occupational Radiation Protection," Code of Federal Regulations, as amended.

29 CFR 1910.120, 1991, "Hazardous Waste Operations and Emergency Response," Code of Federal Regulations, as amended.

29 CFR 1910.1200, 1991, "Hazard Communication," Code of Federal Regulations, as amended.

Comprehensive Environmental Response, Compensation, and Liability Act of 1980 , 42 U.S.C 9601 et seq.

DOE, 1988, Radiation Protection for Occupational Workers, DOE Order 5480.11,

U.S. Department of Energy, Washington, D.C.

DOE, 1990, Occurrence Reporting and Processing of Operations Information, DOE Order 5000.3B, U.S. Department of Energy, Washington, D.C.

DOE-RL, 1993, Hanford Site Hoisting and Rigging Manual, DOE/RL-92-36, Rev. 0,

U.S. Department of Energy, Richland Operations Office, Richland, Washington.

DOE-RL, 1994, Hanford Site Radiological Control Manual, HSRCM-1, U.S. Department of Energy, Richland Operations Office, Richland, Washington.

Ecology, EPA, and DOE, 1994, Hanford Federal Facility Agreement and Consent Order, 2 vols., as amended, Washington State Department of Ecology, U.S. Environmental Protection Agency, and U.S. Department of Energy, Olympia, Washington.

LMHC, 1998, Tank Farm Health and Safety Plan, HNF-SD-WM-HSP-002, Rev. 3, Lockheed Martin Hanford Company, Richland, Washington.

NIOSH, 1985, Occupational Safety and Health Guidance Manual for Hazardous Waste Site Activities, National Institute for Occupational Safety and Health, Washington, D.C.

PHMC, 1998a, Justification for Continued Operation for Tank 241-Z-361, HNF-2024, Rev. 0A, Prepared by the Project Hanford Management Contractors and The Ciron Group LLC, Richland, Washington.

PHMC, 1998b, Job Hazard Analysis, HNF-PRO-079, Rev. 2, Project Hanford Management Contractors, Richland, Washington.

PHMC, 1997a, Hand and Portable Hand Power Tools, HNF-PRO-085, Rev. 1, Project Hanford Management Contractors, Richland, Washington. 
PHMC, 1997b, Machine Guarding, HNF-PRO-086, Rev. 0, Project Hanford Management Contractors, Richland, Washington.

PHMC, 1997c, Walking/Working Surfaces, HNF-PRO-091, Rev. 1, Project Hanford Management Contractors, Richland, Washington.

PHMC, 1997d, Portable Ladders, HNF-PRO-094, Rev. 1, Project Hanford Management Contractors, Richland, Washington.

PHMC, 1997e, Transportation Safety, HNF-PRO-100, Rev. 1, Project Hanford Management Contractors, Richland, Washington.

PHMC, 1997f, Confined Space, HNF-PRO-1 10, Rev. 0, Project Hanford Management Contractors, Richland, Washington.

PHMC, 1997g, Hearing Conservation, HNF-PRO-115, Rev. 0, Project Hanford Management Contractors, Richland, Washington.

PHMC, 1997h, Heat Stress Control, HNF-PRO-121, Rev. 0, Project Hanford Management Contractors, Richland, Washington.

PHMC, 1997i, Asbestos Control - Construction Industry, HNF-PRO-338, Rev. 0, Project Hanford Management Contractors, Richland, Washington.

PHMC, 1997j, Flammable/Combustible Liquids, HNF-PRO-358, Rev. 0, Project Hanford Management Contractors, Richland, Washington.

PHMC, 1997k, Asbestos - Facility Management/General Industry, HNF-PRO-408, Rev. 0, Project Hanford Management Contractors, Richland, Washington.

Resource Conservation and Recovery Act of 1976, 42 U.S.C 6901 et seq.

WAC 173-303, "Dangerous Waste Regulations," Washington Administrative Code, as amended.

WAC 296-62, Part P, "Hazardous Waste Operations and Emergency Response," Washington Administrative Code, as amended.

WHC, 1992, TWRS Administration, HNF-IP-0842, Westinghouse Hanford Company, Richland, Washington.

WHC, 1996, Plutonium Finishing Plant (PFP) Standards/Requirements Identification Document (S/RID), WHC-SD-MP-SRID-003, Rev. 0, Westinghouse Hanford Company, Richland, Washington.

WHC, 1998, Building Emergency Plan for Plutonium Finishing Plant Complex, HNF-IP-0263PFP, Rev. 5, Westinghouse Hanford Company, Richland, Washington. 
ATTACHMENT C-1

TANK 241-Z-361 SITE-SPECIFIC SUMMARY INFORMATION 


\section{SITE IDENTIFICATION}

Project Name:

Site Name:

Site Address:

TWRS Safety Contact Person:

Phone Number:

Proposed Work Dates:
241-Z-361 Tank Vapor Characterization

Tank 241-Z-361

Plutonium Finishing Plant

200 West Area

Department of Energy Hanford Site

Markis Hughey

509-373-2874

Start

September 1998

Stop October 1998

\section{TYPE OF SITE}

$\underline{X}$ Inactive

$\underline{X}$ Industrial facility

Tank 241-Z-361 is an inactive underground tank within the protected area of the Plutonium Finishing Plant (PFP) at the Hanford Nuclear Reservation near Richland, Washington. It is located approximately $240 \mathrm{ft}$ south of Building 236-Z. A cross section and plan view of the tank, with the risers identified alphabetically, are shown in Figure Att-C2-1. Riser " $H$ " has been selected for initial tank venting and vapor sampling. Riser "B" will be used for camera insertion.

Tank 241-Z-361 served as a primary solids settling tank for low-salt waste water from the 234-5Z, 236-Z, and 242-Z Buildings. Historic flows during the operating history of the tank were approximately $2,000,000$ gal of waste water per year. The supernatant from Tank 241-Z-361 was routed to the 216-Z-1A tile field and the 216-Z-1, 216-Z-2, 216-Z-3, and 216-Z-12 Cribs for disposal to ground. The tank was in service from 1949 until 1973, supernatant was removed in 1975 and the tank was isolated in 1985. All tank inlet and outlet pipes and risers have remained sealed since that time, leaving a layer of sludge sediments approximately 94 in. deep in the bottom of the tank.

The tank is known to contain a substantial, but noncritical, quantity of plutonium. The tank is expected to contain and estimated inventory of plutonium ranging from 30 to $70 \mathrm{~kg}$, based on the results of limited sludge sampling and analysis conducted in the 1970s and evaluation of the limited available historic waste stream information. In addition to plutonium, the tank sludge may include constituents from nearly all PFP processes used during the tank's 24-year operational period, but will be dominated by the nonsoluble components of effluents from Buildings 232-Z, 234-5Z, and 236-Z. The exact nature of the solids remaining in the tank is not well described currently. The largest expected contributors of settleable solids and insoluble liquids are expected to have been ash from incinerator scrubber operations, excess acid and 
Figure Att-C2-1. Section and Plan View of Tank 241-Z-361. (not to scale)

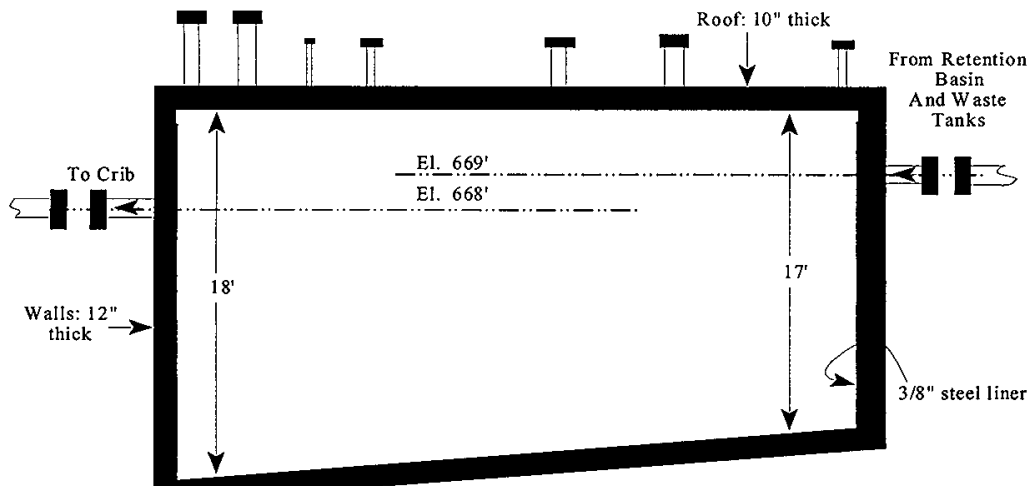

A

Base Mat: $9^{\prime \prime}$ concrete, grout and waterproofing added for a total thickness of 12 "

\section{Centerline Cross-Section}

Tank 241-Z-361

(Not To Scale)
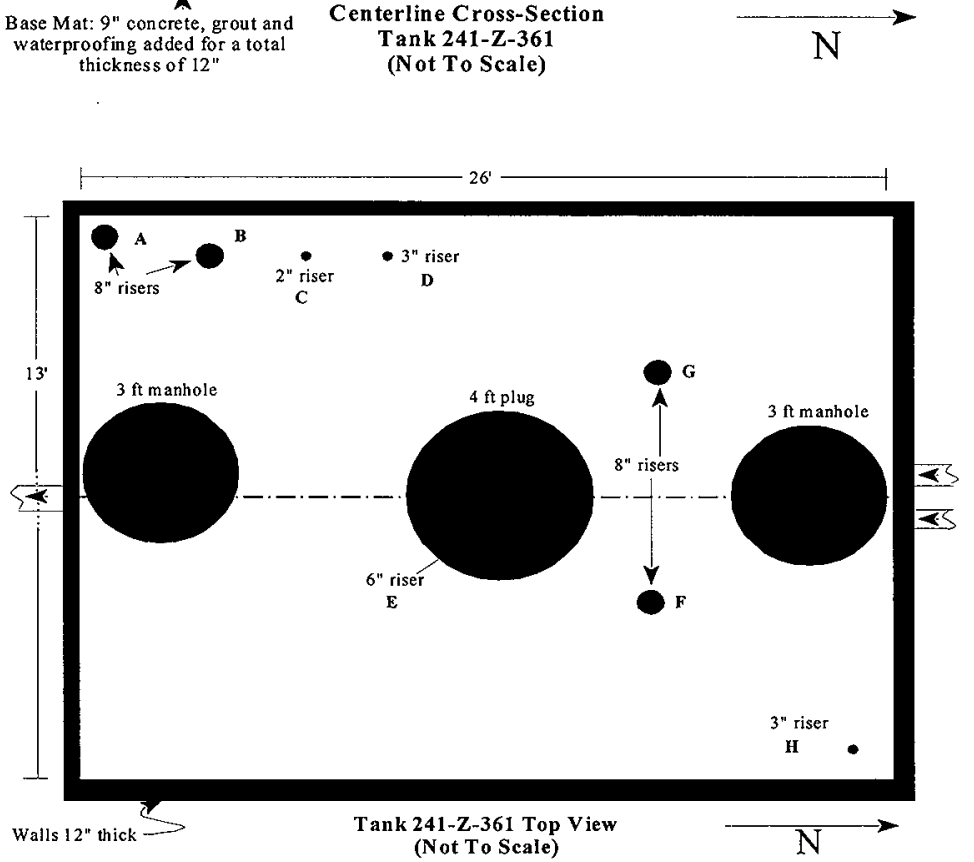
caustic salts from waste neutralization activities, and solvents (e.g., carbon tetrachloride) from plutonium recovery and refining operations and laboratory disposal. Sludge residues analyzed in 1977 exhibited an acidic $\mathrm{pH}$ of approximately 4.0. Elemental analysis of the sludge indicated substantial concentrations of aluminum, calcium, and iron. Carbon content (not specified as organic or inorganic) ranged from less than 1 percent to a maximum in one sample of 6 percent.

An Unreviewed Safety Question (USQ) concerning the status of Tank 241-Z-361 was declared in late 1997 and interim safety controls were imposed. The interim controls are intended to address prevention of inadvertent criticality, potential degradation of tank structural integrity, and the potential for accumulation of flammable vapors in the tank.

\section{HAZARDS AND SAFETY CONCERNS}

Most physical hazards (e.g., trip and fall hazards, vehicle hazards, lifting, and moving material hazards, heat and cold stress) and chemical hazards (e.g., potential toxic vapors) associated with the planned vapor sampling of Tank 241-Z-361 are similar to hazards related to the tank farm operations routinely conducted by Tank Waste Remediation System (TWRS) personnel. Some unique hazards, or potential degree of hazard, have been identified at the Tank 241-Z-361 site. Detailed discussion of the Preliminary Hazard Analysis (PHA) for Tank 241-Z-361 is presented in the Justification for Continued Operation (JCO) for Tank 241-Z-361 (PHMC 1998). These hazards are as follows:

1. potential structural instability of the tank (major concern),

2. potential for release of alpha-emitting radionuclides (known content),

3. potential combustible gas hazards (uncertain),

4. potential toxic vapor hazards (uncertain),

5. mechanical hazards associated with a potentially-pressurized tank (uncertain), and

6. potential criticality hazards (current information indicates noncritical density).

\section{SCOPE OF WORK}

The characterization activities at Tank 241-Z-361 are being conducted as part of the Hanford Site remedial activities under the Comprehensive Environmental Response, Compensation, and Liability Act (CERCLA). The requirements for health and safety planning, training, and safe field operations are specified by the Occupational Safety and Health Administration (OSHA) and codified in 29 CFR 1910.120 .

The objectives of the current activity at Tank 241-Z-361 are as follows:

1. provide chemical analysis of tank vapors for use in defining safety requirements for future intrusive sampling,

2. provide observational data to support evaluation of tank contents, and 
3. provide observational data and limited measurement data to support engineering evaluation of the structural integrity of the tank.

To meet these project objectives, the following activities will be implemented. These activities are described in detail in the Sampling and Analysis Plan prepared for this project.

Prior to implementation of the sampling activity, the site preparation activities will be conducted by Babcock and Wilcox Hanford Corporation (BWHC) staff under a separate planning package. Any changes to this plan based on the results of the load test and initial radiological survey will be incorporated as a safety plan amendment prior to initiating the sampling and analysis activities.

TASK 1. Open the selected tank riser, relieve internal pressure, and monitor the tank atmosphere.

1. Establish an exclusion zone with a weather shelter over the tank top work area, a contamination reduction area, and a support area;

2. Place a glovebag with high-efficiency particulate air (HEPA) filter system over the riser selected for vapor sampling.

3. Perform field monitoring for flammable vapors, toxic substances, and ionizing radiation;

4. Allow the tank pressure to equilibrate to ambient;

5. Mitigate flammable vapors as necessary.

6. Install a breather filter on the riser.

TASK 2. Conduct the investigative activities.

1. Collect a representative sample of the tank vapor;

2. Contain and open a second tank riser for insertion of video and still cameras into the tank;

3. Close the risers when videography is complete. 
TASK 3. Decommission the work area.

1. Containerize all radiologically- or chemically-contaminated investigationderived waste;

2. Dismantle and remove all structures (e.g., weather shelter) and support facilities not identified for future use at the site.

All work will be performed by employees of the Project Hanford Management Contract companies. PFP operations staff will provide plant-specific training to TWRS staff and will manage emergency response requirements.

III. SITE CONTROL (Specify site control requirements and identify on a map the location of work areas and exclusion zones)

The field operations manager will visit the site and identify the most appropriate layout for the exclusion zone, decontamination area, and support area.

An exclusion zone will be established around the selected riser and Tank 241-Z-361 of sufficient size to contain the job equipment and allow a sufficient buffer zone to ensure that respiratory protection and protective clothing are not required at the exclusion zone boundary. Preliminary estimate is for an exclusion zone with at 20 -ft radius from the selected riser. The exclusion zone will be identified for the following requirements based on site monitoring:

1. Respiratory Protection Required;

2. Air Toxics and Flammable Gas Monitoring Required; and

3. Radiation Protection Zone.

The exclusion zone may include a weather shelter erected over the selected tank riser to protect workers from wind, rain, and sun exposure. The size and boundary marking for the exclusion zone will be modified as required based on site monitoring results.

A decontamination area will be established and equipped with sufficient supplies to perform decontamination of personnel and equipment before leaving the controlled area. The decontamination area will also be equipped with containers for used personal protective equipment.

The support area will include a TWRS field support trailer for use as a change room. A shaded rest area will be established and supplied with drinking water.

A diagram of the site with preliminary location of the exclusion zone, decontamination area, and support area locations is shown in Figure Att-C2-2. 
IV. EMERGENCY INFORMATION (NOTE: All TWRS staff performing field work at PFP must attend a PFP Emergency Response Training Session)

Emergency Contacts:

Fire/Rescue:

Ambulance:

Police/Sheriff:

911 or $373-3800$

911 or $373-3800$

911 or $373-3800$

Onsite Medical Facility (clinic):

Yes (Day shift, Mon-Fri)

Health Service Center, 200 West

20th Street, Bldg. 2719 WB (near the

200 West area east gate)

373-2714

PFP Health and Safety Officer:

Yes

Name:

Phone Number:

Matthew Nolen

372-2918

PFP Radiation Control Technician:

Phone Number:

Steve Snyder

373-2634

Hospital Name and Address:

Kadlec Medical Center

888 Swift Blvd.

Richland. WA

(509) 946-4611

Plutonium Finishing Building Emergency Director:

Name:

Phone Number:

PAX:

Shift BED

373-2337

277 
Figure Att-C2-2. Preliminary Site Layout and Exclusion Zone Location, Tank 241-Z-361.

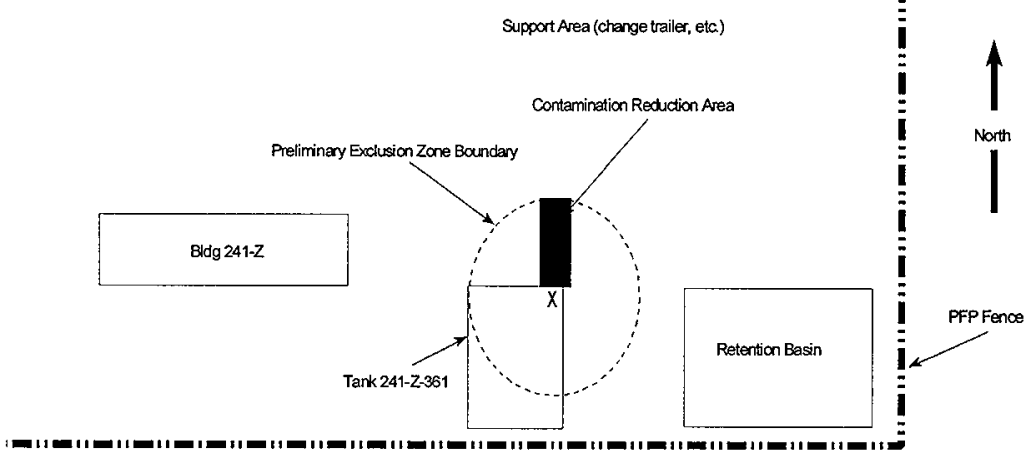

There are some overhead lines paralleling the roadway but not over the work area. These will present hazards to workers when traversing. The road way is not immediately adjacent to the work site but does present a hazard to workers when they are accessing the work area. There are currently signs posted which must be removed and replaced with signs restricting entry to sampling personnel and PFP support only. The existing barrier will serve as the site control boundary. (There are two chain barriers, the outer most is approximately $50 \mathrm{ft}$ in diameter.)

\section{SOURCE/RELEASE CHARACTERIZATION}

Estimated Volume: Approx. 2,000,000 gal of waste water per year for 22 years

\begin{tabular}{|c|c|c|c|c|c|}
\hline Product: & No & Waste: & Yes & Lead Hazard: & No \\
\hline Liquid: & No free liquid remains & Flammable: & ? Uncertain & Asbestos: & ? maybe \\
\hline Sludge: & 94 in. deep in tank & Corrosive: & $\mathrm{pH}$ range $4-7$ & & \\
\hline Solid: & Yes & Reactive: & No & & \\
\hline Empty: & No & Toxic: & ? Uncertain & & \\
\hline Other: & Radioactive (alpha em & r). Plutoniu & and Americil & om plutoni & cay) \\
\hline
\end{tabular}

Tank 241-Z-361 received a high volume of waste water (about 2,000,000 gal/yr) over the course of its service life. This waste water included incinerator scrubber water (probably the largest contributor of plutonium), ion exchange resin backflush water, laboratory wastes (some radiologically contaminated), condensate from process concentrators (largely raw water), and 
water from the fluorinator vacuum jet (the largest single water source to the tank at about 83 percent of the total flow). These waste water streams would typically have contained small quantities of plutonium along with acids and caustics from neutralization actions and other inorganic materials. Organic materials remaining in the tank sludge likely came from the laboratory waste stream. Free liquid was pumped out in 1975.

\section{CHEMICAL HAZARDS}

\section{PRIMARY CHEMICALS OF CONCERN}

\section{Chemical Name}

Plutonium Salts (unspecified)

Carbon Tetrachloride
Highest Reported Concentration (media)

$0.52 \mathrm{~g} / \mathrm{L}$ in sludge (Range of 5 samples $=$ 0.21 to $0.52 \mathrm{~g} / \mathrm{L}$ )

PEL/

ILV IDLH

- none established -
Symptoms/Effects of Acute Exposure

Plutonium is an alphaparticle-emitting radionuclide. Inhalation and/or ingestion of plutonium particulate can cause cancer. Acute exposure to high concentration of plutonium via ingestion or inhalation can cause effects similar to other heavy metals (i.e., lung injury, central nervous system damage, acute gastro-intestinal upset).

Skin and eye irritation. inhalation and ingestion causes damage to nervous system, pulmonary system, and gastrointestinal system. Acute inhalation causes narcosis, coma, and death. A suspected carcinogen. 


\section{PRIMARY CHEMICALS OF CONCERN}

Chemical Name

Ammonia

Tributyl Phosphate

Hydrogen

Methane
Highest Reported Concentration (media)

None Measured

None Measured

None Measured

None Measured
PEL/

$\underline{\text { TLV }} \underline{\text { IDLH }}$

$25 \mathrm{ppm} 300 \mathrm{ppm}$ (NIOSH REL)

$0.2 \mathrm{ppm} 30 \mathrm{ppm}$

(NIOSH REL)

Fire Hazard

Fire Hazard
Symptoms/Effects of Acute Exposure

Powerful and corrosive irritant to eyes, skin, and respiratory tract. Acute exposure produces swelling of eyelids, eye irritation, coughing, difficult breathing, and vomiting. Also

flammable, $\mathrm{LFL}=15$ percent, UFL $=28$ percent.

Moderately toxic by ingestion (low volatility minimizes inhalation hazard). Causes headache nausea, narcosis, paralysis, edema, irritation of skin, eyes, and mucous membranes.

Flammable Gas.

$\mathrm{LFL}=4$ percent, UFL $=75$ percent.

Flammable Gas. $\mathrm{LFL}=5$ percent, $\mathrm{UFL}=15$ percent.

\section{AIR MONITORING}

MONITORING INSTRUMENTATION: (NOTE: Monitoring instruments must be used for all operations unless appropriate rationale or restrictions are provided).

$\underline{\mathrm{X}}$ Photoionization Detector (organic vapor meter [OVM]) Lamp Energy $11.7 \mathrm{eV}$ and $10.6 \mathrm{eV}$ $\mathrm{X}$ Combustible Gas Indicator (CGI).

$\mathrm{X}$ Oxygen Meter

$\mathrm{X}$ Detector Tubes (specify): Ammonia and Carbon Tetrachloride (if volatiles are detected with the OVM).

X. Other (specify: toxic gas, air sampling pumps, etc.): Radiological Monitoring for alpha, beta, and gamma emissions. 


\section{ACTION LEVELS:}

\section{Combustible Gas Indicator (at area of possible accumulation)}

$0-10 \% \quad$ LFL No Explosion Hazard

$10-25 \% \quad$ LFL Potential Explosion Hazard; Notify Site Health and Safety Officer; Implement Control Measures, Monitor continuously

$>25 \% \quad$ LFL Explosion Hazard; Interrupt Task/Evacuate

Oxygen Meter (in workers' breathing zone)

$19.5 \%-23.5 \% \quad$ O2 $\quad$ Oxygen Normal

$19.5 \% \quad$ O2 Oxygen Deficient; Interrupt Task/Evacuate

23.5\% O2 Oxygen Enriched; Interrupt Task/Evacuate

Organic Vapors (nonspecific, indicated by PID or FID readings in workers" breathing zone for 3-minute duration)

$<2 \mathrm{ppm}$

No respiratory protection required unless needed for radiation protection, potential for release, or carbon tetrachloride. Use colorimetric indicator tubes to confirm presence or absence and concentration of ammonia and carbon tetrachloride (see specific action levels for carbon tetrachloride and ammonia).

2 to $25 \mathrm{ppm}$

Level C using full-face APR equipped with GME-H or GME-P100 cartridge. Initiate monitoring at the exclusion zone boundary and extend the boundary as required to ensure that action levels are not exceeded at the exclusion zone boundary.

$>25 \mathrm{ppm}$

Stop work and evacuate the exclusion zone. Continue boundary monitoring. Determine the need for enhanced respiratory protection or engineered controls before continuing work. 
Ammonia (indicated by colorimetric indicator tubes, readings in the workers' breathing zone for 3-minute duration)

$<12 \mathrm{ppm}$

No respiratory protection required unless required by other action levels or for enhanced worker comfort. Continue monitoring for ammonia.

12 to $250 \mathrm{ppm}$

Level C using full-face APR equipped with GME-H or GME-P100 cartridge. Initiate monitoring at the exclusion zone boundary and extend the boundary as required to ensure that action levels are not exceeded at the exclusion zone boundary.

$>250 \mathrm{ppm}$

Stop work and evacuate the exclusion zone. Continue boundary monitoring. Determine the need for enhanced respiratory protection or engineered controls before continuing work.

Carbon Tetrachloride (indicated by colorimetric indicator tubes, readings in workers' breathing zone for 3-minute duration)

$<2 \mathrm{ppm}$

2 to $25 \mathrm{ppm}$

$>25 \mathrm{ppm}$
No respiratory protection required unless required by other action levels. continue monitoring for carbon tetrachloride.

Level B using pressure demand supplied air respirator. Initiate monitoring at the exclusion zone boundary and extend the boundary as required to ensure that action levels are not exceeded at the exclusion zone boundary.

Stop work and evacuate the exclusion zone. Continue boundary monitoring. Determine the need for enhanced respiratory protection or engineered controls before continuing work.

VIII. PHYSICAL HAZARDS

\section{HEAVY EQUIPMENT}

Hoist: $\quad \underline{\text { Yes }}$

Use hoisting and rigging procedures for supporting glove bag and filter assembly

Other: $\quad$ Yes $\quad$ Observe load limits and access restrictions on tank roof and riser load and torque limits. 
CONFINED SPACE ENTRY

No $\quad * *$ Requires Specific H\&S Procedures**

\section{MATERIALS HANDLING}

Flammable Liquid: No

Spoil:

Manual Lifting:

Field equipment, sampling devices

HOT WORK

No Potential for flammable gasses during initial tank opening requires ignition control measures, use of nonsparking tools to open riser, and argon gas available to purge glovebag.

TRAFFIC HAZARDS

$\underline{\text { Yes }}$ Routine plant traffic.

THERMAL STRESS

Heat: Yes_Cold: Yes Depending on weather at time of implementation.

NOISE EXPOSURE

No Not expected to be a problem with this task.

\section{PERSONAL PROTECTIVE EQUIPMENT}

MINIMUM: Substantial footwear Work Clothing

NOTE: $\quad$ Respiratory protection equipment will be supplied and maintained by TWRS. Protective clothing will be provided by PFP. PFP will collect used clothing for laundering or disposal. 
ADDITIONAL: (Specify by Task, Complete Additional Sheets As Needed)

TASK 1: $\quad$ Open Tank Riser, Relieve Internal Pressure, Monitor Tank Atmosphere, Install Breather Filter

\section{RESPIRATORY PROTECTION:}

Pressure demand supplied air respirator.

\section{PROTECTIVE CLOTHING}

Standard anti-contamination clothing ("whites") with hood, gloves, and boot covers.

TASK 2 Collect Vapor Samples and Perform In-tank Camera Work

\section{RESPIRATORY PROTECTION:}

Pressure demand supplied air respirator or full-face air-purifying respirator with GME-H/ GMEP100 cartridges based on results of monitoring during tank opening.

\section{PROTECTIVE CLOTHING}

Standard anti-contamination clothing ("whites") with hood, gloves, and boot covers.

TASK 3 Decommission the Work Area

\section{RESPIRATORY PROTECTION:}

1. Pressure demand supplied air respirator or full-face air-purifying respirator with GME-H/ GME-P100 cartridges until:

a. Riser(s) are closed with breather filters in place and functioning; and

b. Radiological and IH monitoring confirm that action levels are not exceeded, or work is complete within restricted area.

2. No respiratory protection required once conditions in "1." above are met. 


\section{PROTECTIVE CLOTHING}

1. Standard anti-contamination clothing ("whites") with hood, gloves, and boot covers until:

a. Riser(s) are closed with breather filters in place and functioning; and

b. Radiological and IH monitoring confirm that action levels are not exceeded, or work is complete within restricted area.

\section{DECONTAMINATION}

\section{DESCRIBE METHODS USED:}

Personnel: $\quad$ Supplies will be available for dry decontamination (i.e., rags and brushes) and wet decontamination (i.e., water, detergent, brushes, and containers) as specified in the RWP. A personnel face and hand wash station will be established at the perimeter of the decontamination area. Personnel will change in the onsite job trailer and shower in TWRS facilities at Building $2704 \mathrm{HV}$.

Equipment: Contaminated equipment will be sealed in containers and decontaminated or disposed according to PFP procedures or the Environmental Restoration Disposal Facility waste acceptance criteria as discussed in Section 2.9 of this Safety and Analysis Plan.

\section{DISPOSAL}

\section{DESCRIBE METHODS:}

Contaminated materials will be containerized at the site and disposed by PFP staff according to PFP procedures. Uncontaminated solid waste will be bagged and disposed to dumpster. 


\section{DISTRIBUTION SHEET}

\begin{tabular}{|c|c|c|c|c|c|}
\hline \multirow[b]{2}{*}{ Distribution } & \multicolumn{3}{|c|}{ From } & \multicolumn{2}{|l|}{ Page 1 of 2} \\
\hline & \multicolumn{3}{|c|}{ Technical Basis and Planning } & \multicolumn{2}{|c|}{ Date $\quad 09 / 22 / 98$} \\
\hline \multicolumn{4}{|c|}{ Project Title/Work Order } & \multicolumn{2}{|c|}{ EDT No. EDT-622470 } \\
\hline $\begin{array}{l}\text { HNF-2867, Rev. } 0 \\
\text { Plan" }\end{array}$ & Vapor Sampli & $g$ and $A n c$ & ysis & ECN No. N/A & \\
\hline Name & MSIN & $\begin{array}{c}\text { Text } \\
\text { with } \\
\text { All } \\
\text { Attach. }\end{array}$ & Text Only & $\begin{array}{l}\text { Attach. / } \\
\text { Appendix } \\
\text { Only }\end{array}$ & $\begin{array}{l}\text { EDT/ECN } \\
\text { Only }\end{array}$ \\
\hline
\end{tabular}

B\&W Hanford Corp.

D. M. Bogen

J. E. Bramson

F. R. Crawford

T. E. Huber

A. W. Lilly

M. E. Nolen

A. L. Ramble

L. L. Reed

M. L. Schultz

T5-50

T5-54

T5-50

T5-50

T5-11

T5-11

T5-54

T5- 57

T5-45

5
$x$
$x$
$x$
$x$
$x$
$x$
$x$
$x$

Cogema Engineering Corp.

D. S. Haring

K. V. Scott

S7-12

S7 -12

S3-90 $\quad x$

Attach.

R. S. Viswanath

Defense Nuclear Facility Safety Board

D. G. Ogg

A5-52 $X$

U. S. Department of Energy -

Headquarters

J. Polehn

A4-81 $\quad X$

U. S. Department of Energy -

Richland Field office

S. E. Clarke

W. D. Seaborg

A5-15 $X$

R3-79 $X$

Ecology

L. J. Cusack

0 . S. Wang

$\begin{array}{ll}\text { B5-18 } & X \\ \text { B5-18 } & X\end{array}$

Environmental Protection Agency

D. A. Faulk

J. M. Leitch

B5-01 $\quad X$

Fluor Daniel Hanford Corp.

W. E. Toebe

B. D. Williamson

H6-23 $\quad X$

International Technology Corp.

A. M. Hopkins

B3-15 $\quad X$ 


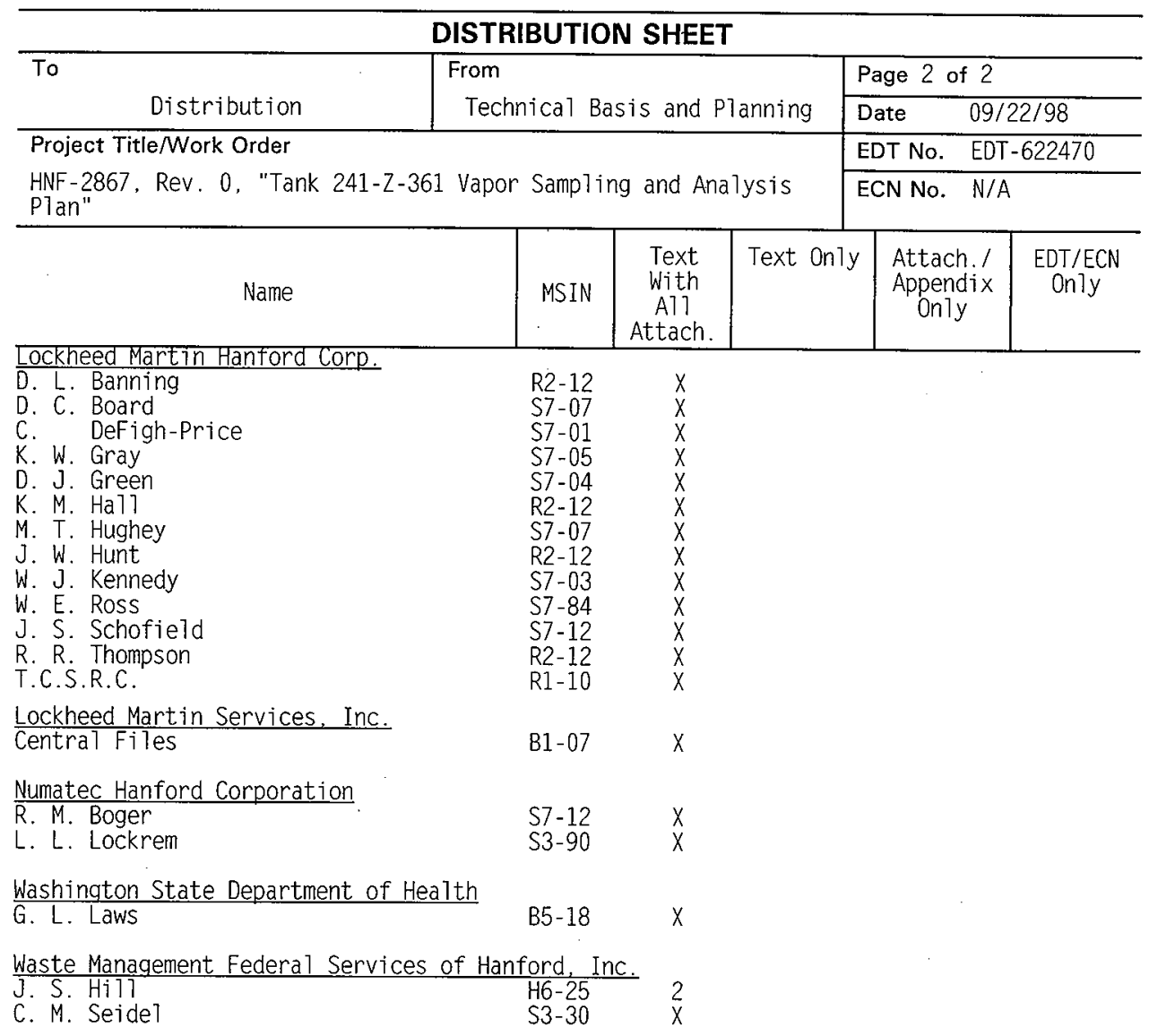

